Cochrane Database of Systematic Reviews

\title{
Inhaled corticosteroids versus long-acting beta2-agonists for chronic obstructive pulmonary disease (Review)
}

Spencer S, Karner C, Cates CJ, Evans DJ

Spencer S, Karner C, Cates CJ, Evans DJ.

Inhaled corticosteroids versus long-acting beta 2 -agonists for chronic obstructive pulmonary disease.

Cochrane Database of Systematic Reviews 2011, Issue 12. Art. No.: CD007033.

DOI: 10.1002/14651858.CD007033.pub3. 
TABLE OF CONTENTS

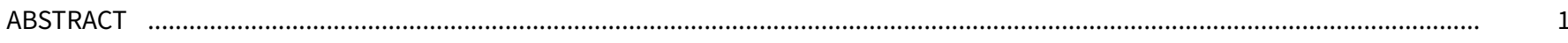

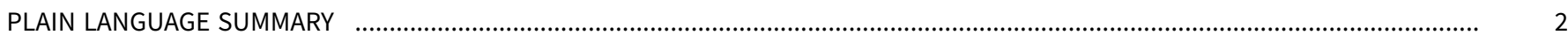

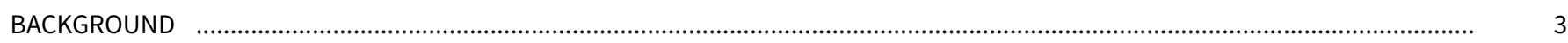

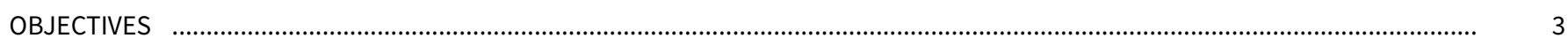

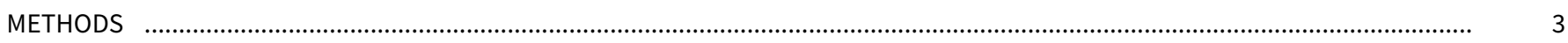

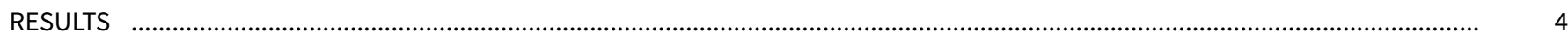

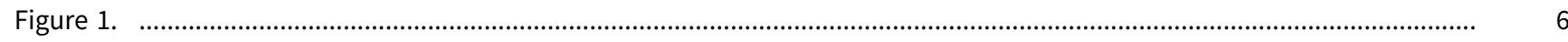

Figure 2.

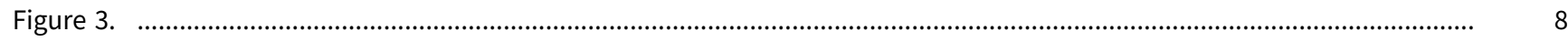

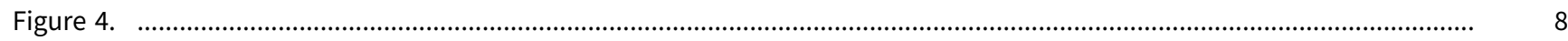

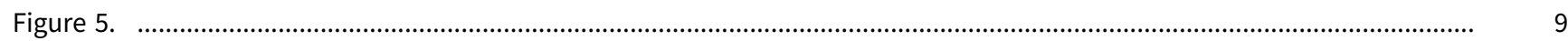

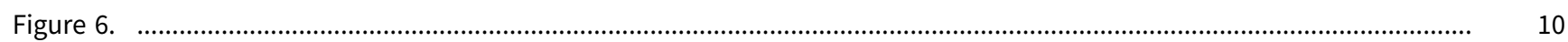

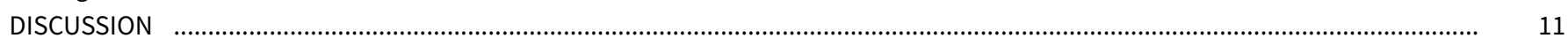

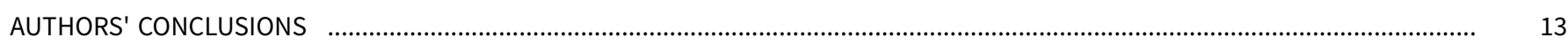

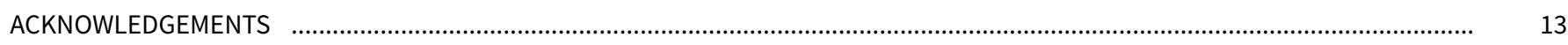

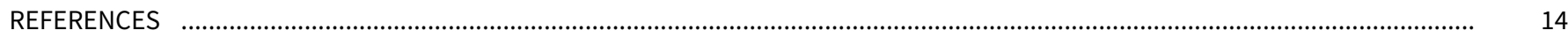

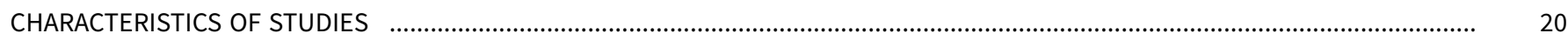

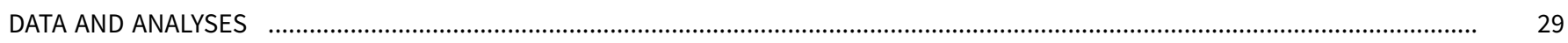

Analysis 1.1. Comparison 1 Inhaled corticosteroids (ICS) versus long-acting beta2-agonists (LABA) by ICS and LABA, Outcome 32

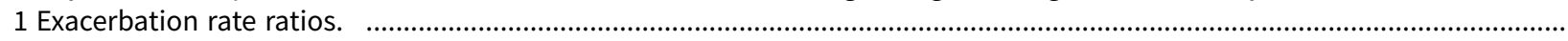

Analysis 1.2. Comparison 1 Inhaled corticosteroids (ICS) versus long-acting beta2-agonists (LABA) by ICS and LABA, Outcome 2 Exacerbations.

Analysis 1.3. Comparison 1 Inhaled corticosteroids (ICS) versus long-acting beta2-agonists (LABA) by ICS and LABA, Outcome 3 Hospitalisations due to exacerbations.

Analysis 1.4. Comparison 1 Inhaled corticosteroids (ICS) versus long-acting beta2-agonists (LABA) by ICS and LABA, Outcome 4 Pneumonia adverse event.

Analysis 1.5. Comparison 1 Inhaled corticosteroids (ICS) versus long-acting beta2-agonists (LABA) by ICS and LABA, Outcome 5 Pneumonia serious adverse event.

Analysis 1.6. Comparison 1 Inhaled corticosteroids (ICS) versus long-acting beta2-agonists (LABA) by ICS and LABA, Outcome 6 Pre-dose FEV1.

Analysis 1.7. Comparison 1 Inhaled corticosteroids (ICS) versus long-acting beta2-agonists (LABA) by ICS and LABA, Outcome 7 Post-dose FEV1.

Analysis 1.8. Comparison 1 Inhaled corticosteroids (ICS) versus long-acting beta2-agonists (LABA) by ICS and LABA, Outcome 8 Mild exacerbations.

Analysis 1.9. Comparison 1 Inhaled corticosteroids (ICS) versus long-acting beta2-agonists (LABA) by ICS and LABA, Outcome 9 Mortality.

Analysis 1.10. Comparison 1 Inhaled corticosteroids (ICS) versus long-acting beta2-agonists (LABA) by ICS and LABA, Outcome 10 Health-related quality of life SGRQ.

Analysis 1.11. Comparison 1 Inhaled corticosteroids (ICS) versus long-acting beta2-agonists (LABA) by ICS and LABA, Outcome 11 Dyspnoea symptom score $0-4$.

Analysis 1.12. Comparison 1 Inhaled corticosteroids (ICS) versus long-acting beta2-agonists (LABA) by ICS and LABA, Outcome 12 Dyspnoea TDI.

Analysis 1.13. Comparison 1 Inhaled corticosteroids (ICS) versus long-acting beta2-agonists (LABA) by ICS and LABA, Outcome 13 Symptoms.

Analysis 1.14. Comparison 1 Inhaled corticosteroids (ICS) versus long-acting beta2-agonists (LABA) by ICS and LABA, Outcome 14 Adverse events.

Analysis 1.15. Comparison 1 Inhaled corticosteroids (ICS) versus long-acting beta2-agonists (LABA) by ICS and LABA, Outcome 15 Serious adverse events (non-fatal).

Analysis 1.16. Comparison 1 Inhaled corticosteroids (ICS) versus long-acting beta2-agonists (LABA) by ICS and LABA, Outcome 16 Withdrawals.

Analysis 2.1. Comparison 2 Inhaled corticosteroids versus long-acting beta2-agonists by length of study, Outcome 1 Exacerbation rate ratios.

Analysis 2.2. Comparison 2 Inhaled corticosteroids versus long-acting beta2-agonists by length of study, Outcome 2 Pneumonia serious adverse event. 
FEEDBACK 
[Intervention Review]

\title{
Inhaled corticosteroids versus long-acting beta2-agonists for chronic obstructive pulmonary disease
}

\author{
Sally Spencer ${ }^{1}$, Charlotta Karner ${ }^{2}$, Christopher J Cates ${ }^{3}$, David J Evans 4 \\ 1Postgraduate Medical Institute, Edge Hill University, Ormskirk, UK. 2BMJ-TAG, BMJ, London, UK. 3Population Health Research Institute, \\ St George's, University of London, London, UK. ${ }^{4}$ Thoracic Medicine, Hemel Hempstead Hospital, Hemel Hempstead, UK
}

Contact: Sally Spencer, Postgraduate Medical Institute, Edge Hill University, St Helens Road, Ormskirk, Lancashire, L39 4QP, UK. spencesa@edgehill.ac.uk.

Editorial group: Cochrane Airways Group.

Publication status and date: Edited (no change to conclusions), published in Issue 4, 2018.

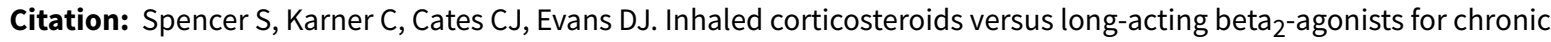
obstructive pulmonary disease. Cochrane Database of Systematic Reviews 2011, Issue 12. Art. No.: CD007033. DOI: 10.1002/14651858.CD007033.pub3.

Copyright $\odot 2018$ The Cochrane Collaboration. Published by John Wiley \& Sons, Ltd.

\section{A B S T R A C T}

\section{Background}

Long-acting beta ${ }_{2}$-agonists and inhaled corticosteroids can be used as maintenance therapy by patients with moderate to severe chronic obstructive pulmonary disease. These interventions are often taken together in a combination inhaler. However, the relative added value of the two individual components is unclear.

\section{Objectives}

To determine the relative effects of inhaled corticosteroids (ICS) compared to long-acting beta 2 -agonists (LABA) on clinical outcomes in patients with stable chronic obstructive pulmonary disease.

\section{Search methods}

We searched the Cochrane Airways Group Specialised Register of trials (latest search August 2011) and reference lists of articles.

\section{Selection criteria}

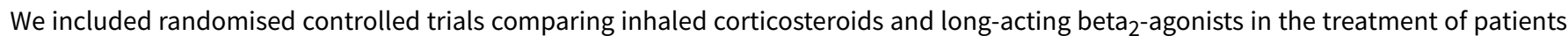
with stable chronic obstructive pulmonary disease.

\section{Data collection and analysis}

Three authors independently assessed trials for inclusion and then extracted data on trial quality, study outcomes and adverse events. We also contacted study authors for additional information.

\section{Main results}

We identified seven randomised trials (5997 participants) of good quality with a duration of six months to three years. All of the trials compared ICS/LABA combination inhalers with LABA and ICS as individual components. Four of these trials included fluticasone and salmeterol monocomponents and the remaining three included budesonide and formoterol monocomponents. There was no statistically significant difference in our primary outcome, the number of patients experiencing exacerbations (odds ratio $(\mathrm{OR}) 1.22 ; 95 \% \mathrm{Cl} 0.89$ to 1.67), or the rate of exacerbations per patient year (rate ratio (RR) $0.96 ; 95 \% \mathrm{Cl} 0.89$ to 1.02 ) between inhaled corticosteroids and long-acting beta $_{2}$-agonists. The incidence of pneumonia, our co-primary outcome, was significantly higher among patients on inhaled corticosteroids than on long-acting beta ${ }_{2}$-agonists whether classified as an adverse event (OR 1.38; $95 \% \mathrm{Cl} 1.10$ to 1.73 ) or serious adverse event (Peto 
OR $1.48 ; 95 \% \mathrm{Cl} 1.13$ to 1.93$)$. Results of the secondary outcomes analysis were as follows. Mortality was higher in patients on inhaled corticosteroids compared to patients on long-acting beta 2 -agonists (Peto OR 1.17; $95 \% \mathrm{Cl} 0.97$ to 1.42), although the difference was not

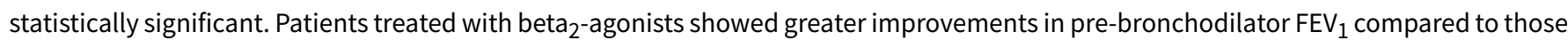
treated with inhaled corticosteroids (mean difference (MD) $18.99 \mathrm{~mL} ; 95 \% \mathrm{Cl} 0.52$ to 37.46), whilst greater improvements in health-related quality of life were observed in patients receiving inhaled corticosteroids compared to those receiving long-acting beta ${ }_{2}$-agonists (St George's Respiratory Questionnaire (SGRQ) MD - $0.74 ; 95 \% \mathrm{Cl}-1.42$ to -0.06). In both cases the differences were statistically significant but rather small in magnitude. There were no statistically significant differences between ICS and LABA in the number of hospitalisations due to exacerbations, number of mild exacerbations, peak expiratory flow, dyspnoea, symptoms scores, use of rescue medication, adverse events, all cause hospitalisations, or withdrawals from studies.

\section{Authors' conclusions}

Placebo-controlled trials have established the benefits of both long-acting beta-agonist and inhaled corticosteroid therapy for COPD patients as individual therapies. This review, which included trials allowing comparisons between LABA and ICS, has shown that the two therapies confer similar benefits across the majority of outcomes, including the frequency of exacerbations and mortality. Use of long-acting beta-agonists appears to confer a small additional benefit in terms of improvements in lung function compared to inhaled corticosteroids. On the other hand, inhaled corticosteroid therapy shows a small advantage over long-acting beta-agonist therapy in terms of health-related quality of life, but inhaled corticosteroids also increase the risk of pneumonia. This review supports current guidelines advocating long-acting beta-agonists as frontline therapy for COPD, with regular inhaled corticosteroid therapy as an adjunct in patients experiencing frequent exacerbations.

\section{PLAIN LANGUAGE SUMMARY}

\section{Comparing inhaled corticosteroids with long-acting beta ${ }_{2}$-agonists in treating chronic obstructive pulmonary disease (COPD)}

Inhalers containing corticosteroids, long-acting beta 2 -agonists or both can be used to treat severe chronic obstructive pulmonary disease (COPD). However, the benefits and harms of the two individual treatments are unclear when comparing one treatment with the other.

We looked at clinical trials that compared the two kinds of inhalers to find the effects of each on health and well-being in patients with COPD. We found seven studies (involving 5997 participants) comparing the long-term benefits and side effects of inhaled corticosteroids and longacting beta ${ }_{2}$-agonists for treating COPD. Overall, we found no significant difference between the two drugs in the number of people having an exacerbation (worsening of COPD symptoms). More people taking inhaled corticosteroids suffered episodes of pneumonia compared to

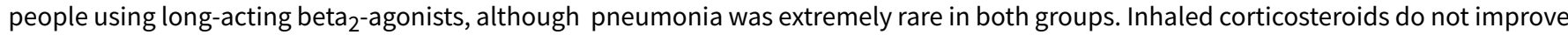
lung function as much as long-acting beta ${ }_{2}$-agonists but did improve patients' quality of life more than long-acting beta ${ }_{2}$-agonists. The differences in lung function and quality of life were rather small. 


\section{B A C K G R O U N D}

The Global Initiative for Chronic Obstructive Lung Disease (GOLD) guidelines for the treatment of patients with chronic obstructive pulmonary disease (COPD) state that beta 2 -agonists are a central therapy for the alleviation of symptoms (GOLD 2010). Inhaled long-acting beta $_{2}$-agonists (LABAs) improve lung function (Boyd 1997) and health-related quality of life (Jones 1997) and are recommended by current National Institute for Health and Clinical Excellence (NICE) guidelines in the treatment of COPD (NICE 2010). A Cochrane review of the efficacy of LABA in people with stable COPD reported significant benefits on a range of outcomes including improved lung function, improved health-related quality of life and fewer exacerbations of COPD, confirming LABA as an effective therapy in COPD (Appleton 2006).

Long-term treatment with inhaled corticosteroids (ICS) has not been found to modify the rate of decline in forced expiratory volume in one second $\left(\mathrm{FEV}_{1}\right.$ ) (Pauwels 1999; Vestbo 1999; Burge 2000; Lung Health 2000) but, in moderate or severe COPD, ICS has been shown to reduce the frequency and severity of exacerbations (Burge 2000). Both the GOLD and NICE guidelines recommend the addition of regular treatment with inhaled corticosteroids to bronchodilator treatment for patients with an $\mathrm{FEV}_{1}<50 \%$ predicted who are symptomatic or suffer repeated exacerbations of COPD (GOLD 2010; NICE 2010). Treatment with inhaled corticosteroids has also been shown to reduce the rate of deterioration in healthrelated quality of life (Spencer 2001) through a reduction in exacerbation frequency (Spencer 2003). A Cochrane review of ICS for stable COPD reported a range of therapeutic benefits including improved lung function, improved health-related quality of life and fewer exacerbations of COPD, with no associated impact on mortality rates compared to placebo (Yang 2007).

This evidence for the effectiveness of LABA and ICS for COPD has led to the development of combination therapies that contain both an inhaled corticosteroid and a long-acting beta 2 -agonist (Calverley 2003 a). However, the relative benefits of LABA and ICS in the treatment of COPD has not been fully explored. Recent findings from clinical trials suggest that the impact of combination therapies on a range of outcomes may not be a simple additive effect, for example in the comparisons of combination versus monocomponents (ICS or LABA) for exacerbation rates (Calverley 2003 a; Calverley 2007). This makes an investigation of the relative added value of LABAs compared to ICS even more important. Of particular concern is the relative impact of the treatments on adverse outcomes such as mortality.

The aim of this review is to evaluate the relative added value of inhaled corticosteroids compared to long-acting beta ${ }_{2}$-agonists on clinical endpoints.

\section{O B J E C T IVES}

To determine the relative effects of inhaled corticosteroids and long-acting beta ${ }_{2}$-agonists on clinical endpoints in patients with stable COPD.

\section{METHODS}

\section{Criteria for considering studies for this review}

Types of studies

We included published and unpublished randomised trials (RCTs) that included comparisons between inhaled corticosteroids and long-acting beta ${ }_{2}$-agonists in the treatment of patients with stable COPD.

\section{Types of participants}

We included patients with a clinical diagnosis of COPD, and not asthma, that fulfilled any of the following internationally recognised diagnostic guidelines: American Thoracic Society (ATS), European Respiratory Society (ERS) and Global Initiative for Chronic Obstructive Lung Disease (GOLD). We only included studies with patients who were clinically stable at study entry, as defined by an exacerbation-free study run-in period, and that had excluded patients with significant comorbidity.

\section{Types of interventions}

We included regular inhaled corticosteroids compared with regular inhaled long-acting beta 2 -agonists administered by any inhalation device. We included the following inhaled corticosteroid versus inhaled long-acting beta ${ }_{2}$-agonist comparisons.

\subsection{Formoterol versus beclomethasone \\ 1.2. Formoterol versus budesonide \\ 1.3. Formoterol versus ciclesonide \\ 1.4. Formoterol versus fluticasone \\ 1.5. Formoterol versus mometasone \\ 1.6. Formoterol versus triamcinolone}

2.1. Salmeterol versus beclomethasone

2.2. Salmeterol versus budesonide

2.3. Salmeterol versus ciclesonide

2.4. Salmeterol versus fluticasone

2.5. Salmeterol versus mometasone

2.6. Salmeterol versus triamcinolone

We allowed long-acting anticholinergics, for example tiotropium, as co-interventions.

\section{Types of outcome measures}

\section{Primary outcomes}

1. Moderate or severe exacerbations: defined as those requiring treatment with antibiotics or oral corticosteroids, or both, expressed as the total number of exacerbations

2. Hospitalisations due to exacerbations

3. Pneumonia

\section{Secondary outcomes}

1. All cause mortality

2. Mild exacerbations: defined as a worsening of symptoms not necessitating treatment with antibiotics or oral corticosteroids, expressed as the total number of exacerbations

3. Change in forced expiratory volume in 1 second $\left(\mathrm{FEV}_{1}\right)$ and other measures of pulmonary function

4. Quality of life scales 
5. Symptom scores of breathlessness and other symptom scores

6. Inhaled rescue medication use during the treatment period

7. Adverse events

8. All cause hospitalisations

9. Withdrawal from study

\section{Search methods for identification of studies}

\section{Electronic searches}

We searched the Cochrane Airways Group Specialised Register for randomised controlled trials. The Register is derived from systematic searches of bibliographic databases including the Cochrane Central Register of Controlled Trials (CENTRAL) (The Cochrane Library), MEDLINE, EMBASE and CINAHL, and handsearching of respiratory journals and meeting abstracts (please see the Airways Group search methods for further details). All records in the Register coded as 'COPD' were searched using the following strategy:

((bronchodilator ${ }^{\star}$ AND long*) OR ((beta* AND agonist*) AND longacting OR "long acting") OR ((beta* AND adrenergic*) AND longacting OR "long acting") OR salmeterol OR Serevent OR formoterol OR Foradil OR Oxis OR eformoterol OR fenoterol OR bambuterol OR Bambec) AND ((“steroid OR steroid* OR corticosteroid* OR corticoid $^{\star}$ OR glucocorticoid* OR "adrenal cortex hormones") OR (fluticasone OR Flixotide OR beclomethasone OR beclometasone OR QVAR OR budesonide OR Pulmicort OR mometasone OR Asmanex OR triamcinolone OR Kenalog OR ciclesonide OR Alvesco OR CIC OR flunisolide OR Aerobid)).

\section{Searching other resources}

We checked the reference lists of all included randomised controlled trials and review articles for additional references. We contacted authors of identified randomised trials about other published and unpublished studies.

\section{Data collection and analysis}

\section{Selection of studies}

Two of us (SS and DJE) independently assessed the titles and abstracts of all retrieved trials. Using the full text of each study, we independently selected trials for inclusion in the review. We resolved disagreements about relevance by consensus.

\section{Data extraction and management}

Three of us (SS, DJE and CK) independently extracted data from the included studies and the data were then aggregated. We sought data missing from the publications through correspondence with the study authors. We extracted variance data from all arms of the included studies to enable calculation of the variance of the ICS versus LABA difference, where this was not reported. We combined data from all trials using RevMan 5.

\section{Assessment of risk of bias in included studies}

We assessed the risk of bias for all included studies according to recommendations outlined in the Cochrane Handbook of Systematic Reviews of Interventions (Higgins 2008) for the following items.

1. Allocation sequence generation.
2. Concealment of allocation.

3. Blinding of participants and investigators.

4. Incomplete outcome data.

5. Selective outcome reporting.

We graded each potential source of bias as either low, high or unclear. We noted other sources of bias.

\section{Measures of treatment effect}

We summarised proportional outcomes, such as the proportion who improved, using an odds ratio (OR) with a fixed-effect MantelHaenszel model, unless zero cells were present in which case we used Peto odds ratios. We analysed continuous data as weighted mean difference (MD) with a fixed-effect model. In trials where individual group data were not reported and treatment effects were only given as differences between treatment groups, we analysed data using the generic inverse variance (GIV) function with a fixedeffect model. A number of trials reported the difference between ICS and LABA arms but did not report the appropriate variance around this difference. In this case, we calculated the variance of the difference between ICS and LABA using the variances of all the trial arms, see Appendix 1. We did not impute variances from other studies in any of the analyses in this review.

\section{Dealing with missing data}

We contacted investigators and manufacturers of the preparations for missing data, where necessary.

\section{Assessment of heterogeneity}

We performed tests for heterogeneity using the $1^{2}$ statistic in RevMan 5. Where 12 was greater than $20 \%$ we also conducted a sensitivity analysis by pooling data with a random-effects model and comparing this to the results of the fixed-effect model.

\section{Assessment of reporting biases}

We planned to inspect funnel plots for signs of publication bias.

\section{Subgroup analysis and investigation of heterogeneity}

We pooled the analysis across studies but performed subgroup analyses for each corticosteroid versus beta b $_{2}$-agonist comparison. The treatment periods were stratified into less than one year, and more than one year. We pooled studies with different doses of the same inhaled corticosteroid and planned to carry out subgroup testing to compare different doses, when the data allowed this.

\section{Sensitivity analysis}

We planned to carry out sensitivity analysis based on study quality.

\section{RE S U L T S}

\section{Description of studies}

\section{Results of the search}

The electronic search returned 431 references. From these, we identified 115 as potentially relevant. After further assessment we found that 99 references belonging to seven studies were eligible and 16 references were excluded with reasons given. The latest search was run in August 2011. 


\section{Included studies}

Full details of all included studies can be found in the Characteristics of included studies table.

\section{Study design}

All the included studies were multi-centre, randomised, doubleblind, placebo-controlled with a parallel-group design. TORCH 2007 was the longest trial with a treatment duration of three years. Calverley 2003, Szafranski 2003 and TRISTAN 2003 were one-year studies, and Hanania 2003, Mahler 2002 and Tashkin 2008 had a duration of six months.

\section{Sample size}

The studies included 5997 participants of which 2991 were randomised to LABA treatment and 3006 to ICS treatment. TORCH 2007 was the largest study with 3093 participants. The other studies had between 300 to 800 participants each.

\section{Participants}

The mean age of participants was 64 years. The average gender distribution varied from 62\% males in Hanania 2003 to $78 \%$ in Szafranski 2003. All participants were diagnosed with COPD according to GOLD 2010, ATS or ERS classifications. Disease severity in the included studies ranged from moderate to very severe COPD. The average baseline lung function varied from 1.0 to $1.3 \mathrm{~L}_{\text {for }} \mathrm{FEV}_{1}$, and from $36 \%$ to $45 \%$ for $\mathrm{FEV}_{1}$ predicted, across the studies.

\section{Interventions}

In Calverley 2003, Szafranski 2003, and Tashkin 2008 the LABA used was formoterol at $4.5 \mu \mathrm{g}$, two inhalations twice daily; and the ICS was budesonide, two inhalations twice daily at 200, 200 and $160 \mu$ g, respectively. Hanania 2003, Mahler 2002, TORCH 2007 and TRISTAN 2003 looked at the LABA salmeterol and the ICS fluticasone. Salmeterol was used at a dose of $50 \mu \mathrm{g}$ twice daily and the ICS fluticasone at $500 \mu \mathrm{g}$ twice daily. The exception was Hanania 2003, which used fluticasone at a dose of $250 \mu \mathrm{g}$ twice daily.

\section{Permitted co-treatment}

All included studies allowed reliever medication, such as terbutaline or salbutamol, when necessary to relieve symptoms. In the majority of studies tiotropium was not a permitted co-treatment. Calverley 2003 also allowed courses of oral corticosteroids (maximum three weeks per course) and antibiotics in the event of exacerbations, and parenteral steroids or nebulised treatment (single injections or inhalations), or both, at emergency visits. Tashkin 2008 allowed oral and parenteral corticosteroids (not depot formulations), acute use of xanthines, increased use of inhaled beta-adrenoceptor agonists and ipratropium bromide, nebulized beta-adrenoceptor agonists and ipratropium bromide. TORCH 2007 allowed patients to continue any medication for COPD other than corticosteroids and inhaled long-acting bronchodilators. TRISTAN 2003 allowed regular treatment with anticholinergics, mucolytics and theophylline. All non-COPD medications could be continued if the dose remained constant, whenever possible, and if their use would not be expected to affect lung function.

\section{Outcomes}

All the included studies looked at COPD exacerbations, $\mathrm{FEV}_{1}$, health-related quality of life and adverse events. Most of the studies also recorded symptoms, use of reliever medication, dyspnoea and peak expiratory flow (PEF).

\section{Excluded studies}

Fourteen references from 11 studies were excluded as they failed to meet the eligibility criteria for the review (see Characteristics of excluded studies). Nine of these did not include trial arms of monotreatment with inhaled corticosteroid and long-acting beta $2^{-}$ agonist (Della Cioppa 2001; Cazzola 2003; Barnes 2005; Gosman 2006; Jiang 2009; Nungtjik 2009; Worth 2009; Mittmann 2010). The remaining two references were reviews (Lyseng-Williamson 2002; Reynolds 2004).

\section{Risk of bias in included studies}

An assessment of the risk of bias for each study is presented in the Characteristics of included studies, and an overview of the findings is shown in Figure 1. 
Figure 1. Risk of bias summary: review authors' judgements about each 'Risk of bias' item for each included study.

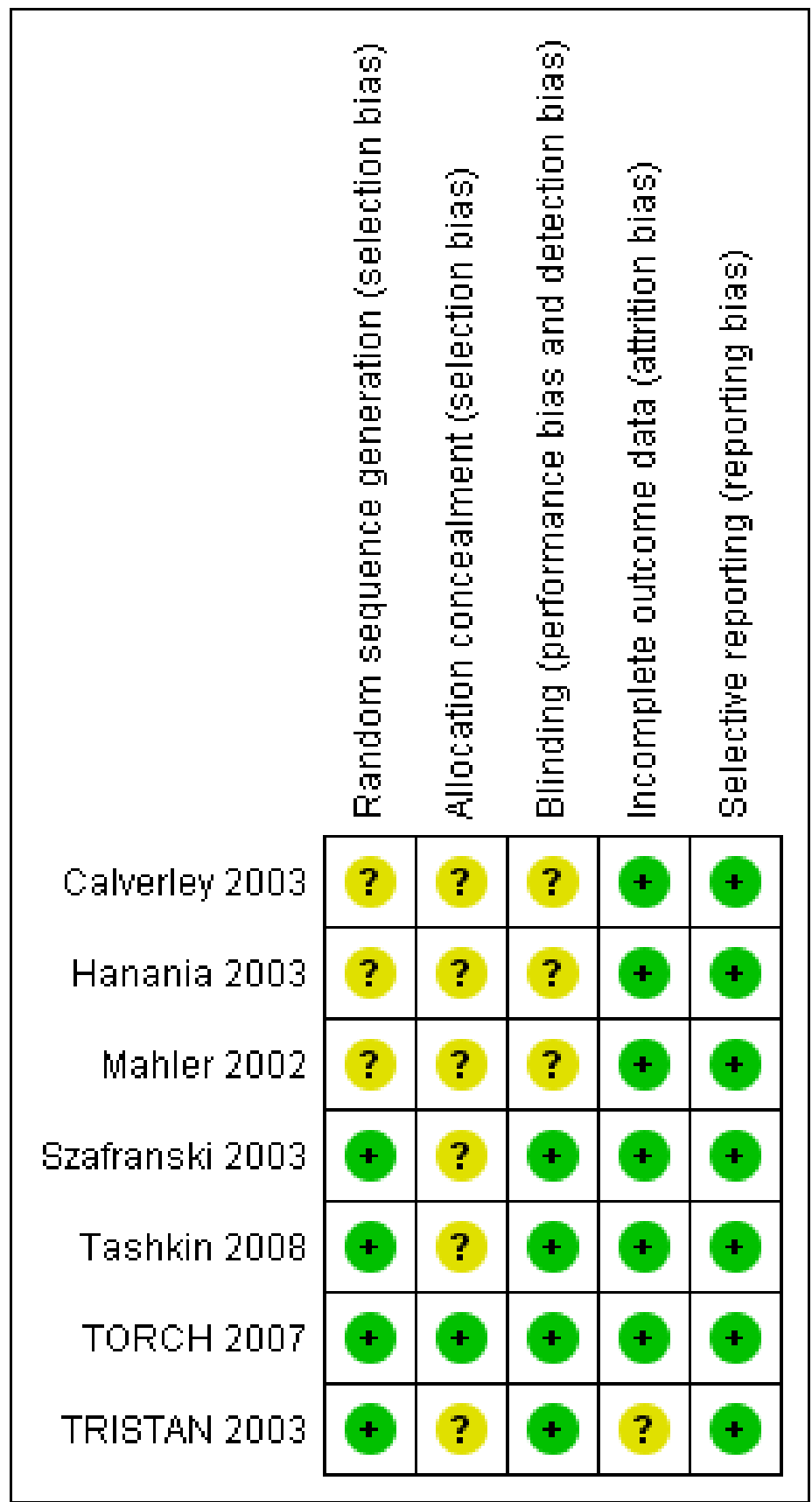

\section{Allocation}

Szafranski 2003, Tashkin 2008, TORCH 2007 and TRISTAN 2003 reported using computer-generated randomisation schedules for list generation and were therefore judged to be at low risk of bias. Patients who met the inclusion criteria were assigned the next consecutive treatment number from the generated list. Information regarding sequence generation for the other included studies, and details of allocation concealment procedures for all included studies (except TORCH 2007), were not reported and these were judged to be at unclear risk of bias. In TORCH 2007 the principal investigators were provided with the participant's treatment number as well as a treatment pack number through an automated 24-hour telephone number. For all other studies there were insufficient descriptions of allocation concealment methods to allow judgement of anything other than unclear risk of bias against this criterion.

\section{Blinding}

All the included studies were double-blind, though only Szafranski 2003, Tashkin 2008, TORCH 2007 and TRISTAN 2003 gave details of the blinding of participants and clinicians, permitting a judgement of low risk of bias. In Szafranski 2003 all the inhalers were identical to ensure that the patients, pharmacists and the investigators were blinded to the allocated treatment. In Tashkin 2008 patients received both a pressurized metered-dose inhaler and a dry powder inhaler containing either active treatment or placebo, or

Inhaled corticosteroids versus long-acting beta ${ }_{2}$-agonists for chronic obstructive pulmonary disease (Review) 
combinations of active treatment and placebo, as appropriate. In TORCH 2007 and TRISTAN 2003 study drugs were packaged in identical inhaler devices to ensure that both the patients and investigators were unaware of treatment allocation.

\section{Incomplete outcome data}

All included studies had substantial withdrawal rates $(20 \%$ to $40 \%$ ). However, the rates were broadly comparable in the ICS and LABA treatment groups with the exception of Mahler 2002, where there was a notable difference between ICS (40\%) and LABA (28\%) dropout rates. Most of the studies, including Mahler 2002, described intention-to-treat data analyses, though TRISTAN 2003 did not state whether follow-up data were collected for discontinued patients.

\section{Selective reporting}

All included trials adequately reported the outcome data specified in the published methods and were therefore judged to be at low risk of bias for this criterion.

\section{Effects of interventions}

Please note that a number of trials reported the difference between ICS and LABA arms but did not report the appropriate variance around this difference. In these cases we calculated the variance of the difference between ICS and LABA using the variances of all the trial arms, see Appendix 1. Variances were not imputed from other studies in any of the analyses in this review.

\section{Inhaled corticosteroid versus long-acting beta $_{2}$-agonist}

\section{Primary outcome: exacerbations}

Four studies (4750 participants) reported exacerbation rate ratios between ICS or LABA and placebo or a ICS/LABA combination (Calverley 2003; Szafranski 2003; TRISTAN 2003; TORCH 2007). Analysis of the rate ratio (RR) between ICS and LABA was not statistically significant (RR 0.96; 95\% confidence interval (CI) 0.89 to 1.02) (Analysis 1.1), and the $\mathrm{Cl}$ was narrow enough to exclude large differences between the two treatments, see Figure 2. There was no evidence of a class effect when comparing the fluticasone/ salmeterol trials to the budesonide/formoterol trials in a subgroup analysis $\left(\mathrm{Chi}^{2}=1.57, \mathrm{df}=1, \mathrm{P}=0.21\right)$. There was no statistically significant difference in exacerbation RR between studies of $\leq 1$ year and $>1$ year of treatment $\left(\mathrm{Chi}^{2}=0.11, \mathrm{df}=1, \mathrm{P}=0.75\right)$, see Figure 3 . Tashkin 2008 was excluded from the analysis because $\mathrm{Cls}$, $P$ values or standard deviations were not reported for any of the rate ratio comparisons. Two studies comparing fluticasone versus salmeterol reported the number of patients experiencing exacerbations requiring either treatment with antibiotics or corticosteroids, or both, or hospitalisation during the treatment period (Mahler 2002; Hanania 2003) (688 participants, Analysis 1.2). In these studies, although more patients on ICS (136/351) suffered exacerbations than on LABA (115/337), the Cls were wide and there was no statistically significant difference between the groups (OR 1.22;95\% $\mathrm{Cl} 0.89$ to 1.67$)$.

\section{Figure 2. Forest plot of comparison: 1 Inhaled corticosteroids versus long-acting beta 2 -agonists by ICS and LABA,} outcome: 1.1 Exacerbation rate ratios.

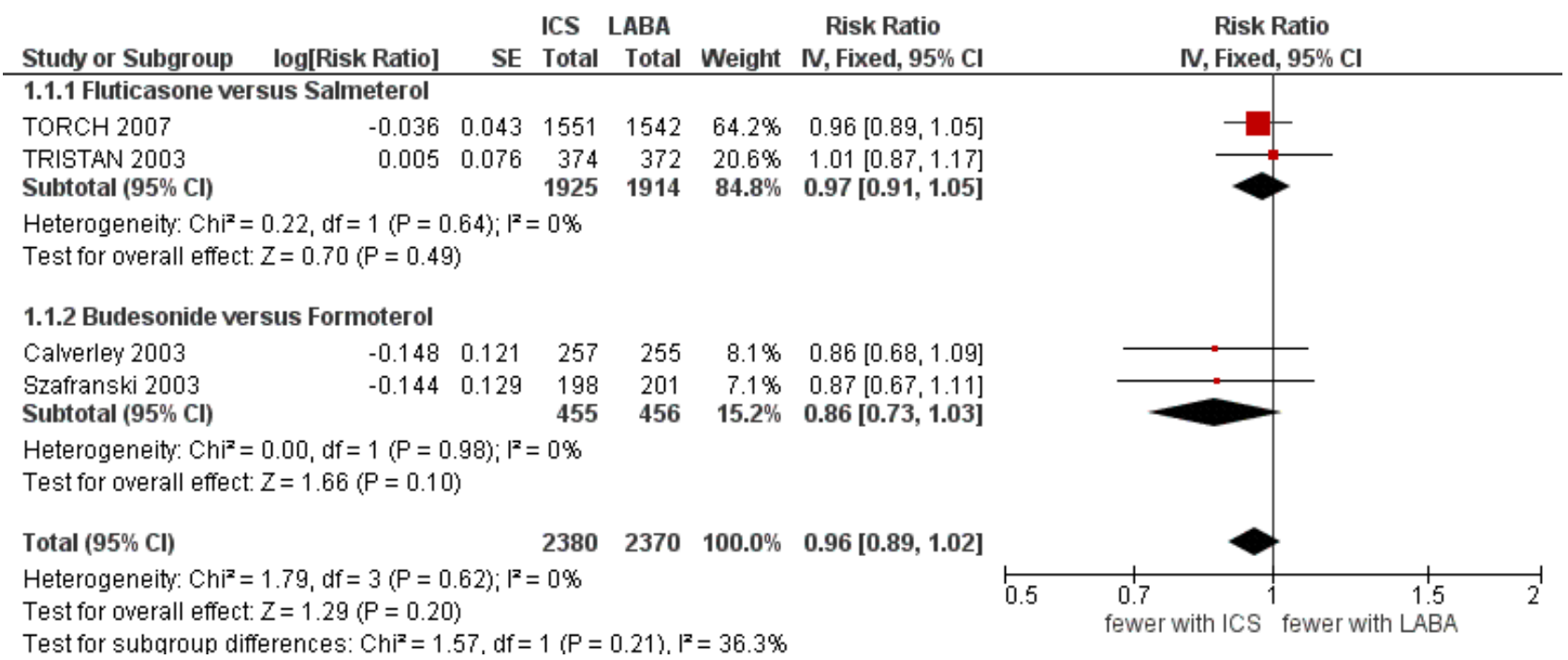


Figure 3. Forest plot of comparison: 2 Inhaled corticosteroids versus long-acting beta 2 -agonists by length of study, outcome: 2.1 Exacerbation rate ratios.

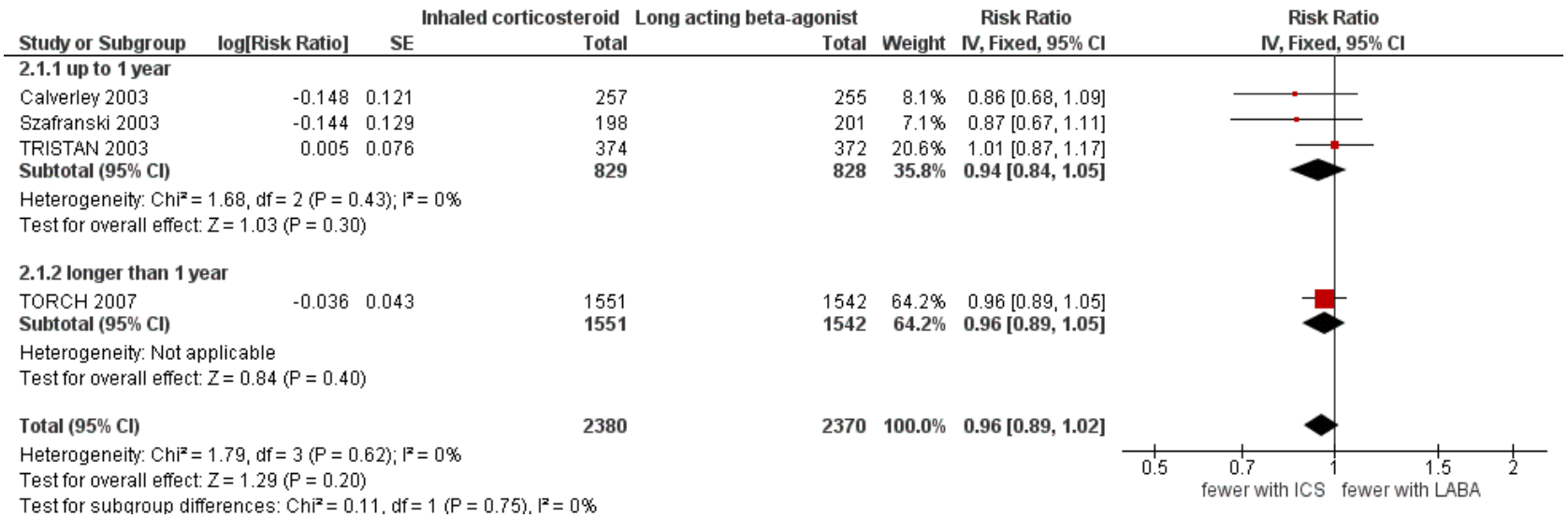

\section{Primary outcome: hospitalisations due to exacerbations}

Exacerbations leading to hospitalisations were only reported in a single trial (TORCH 2007) with 3093 participants. A comparison of rate ratios showed there was no significant difference in the risk of hospitalisation due to exacerbation between fluticasone and salmeterol (RR 1.07; 95\% Cl 0.91 to 1.26) (Analysis 1.3).

\section{Primary outcome: pneumonia}

Three studies (4164 participants) reported the number of patients suffering from episodes of pneumonia as adverse events (Calverley 2003; TORCH 2007; Tashkin 2008). The three-year study, TORCH 2007 (3093 participants), showed a significantly higher incidence of pneumonia in patients on fluticasone compared to patients on salmeterol (OR $1.43 ; 95 \% \mathrm{Cl} 1.13$ to 1.81 ). The other two shorter studies (Tashkin 2008: six months, Calverley 2003: 1 year), comparing budesonide/formoterol, had few events and wide Cls and showed no statistically significant difference between the treatment groups (OR $0.84 ; 95 \% \mathrm{Cl} 0.36$ to 1.96 ), see Figure 4. There was no significant difference between the results of TORCH 2007 and the other two studies $\left(\mathrm{Chi}^{2}=1.43, \mathrm{df}=1, \mathrm{P}=0.23\right)$. Overall there was an increased risk of pneumonia on ICS compared to LABA (OR 1.38; $95 \% \mathrm{Cl} 1.10$ to 1.73 ) as shown in Figure 4. This result is also shown as a Cates plot in Figure 5, which demonstrates that for every 100 people treated over 2.4 years, there would be seven pneumonia cases if they were all given LABA and nine pneumonia cases if they were all given ICS. These calculations are based on the assumption that, in such a hypothetical situation, the patients were not also receiving the other treatment.

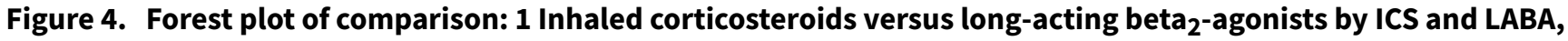
outcome: 1.4 Pneumonia adverse event.

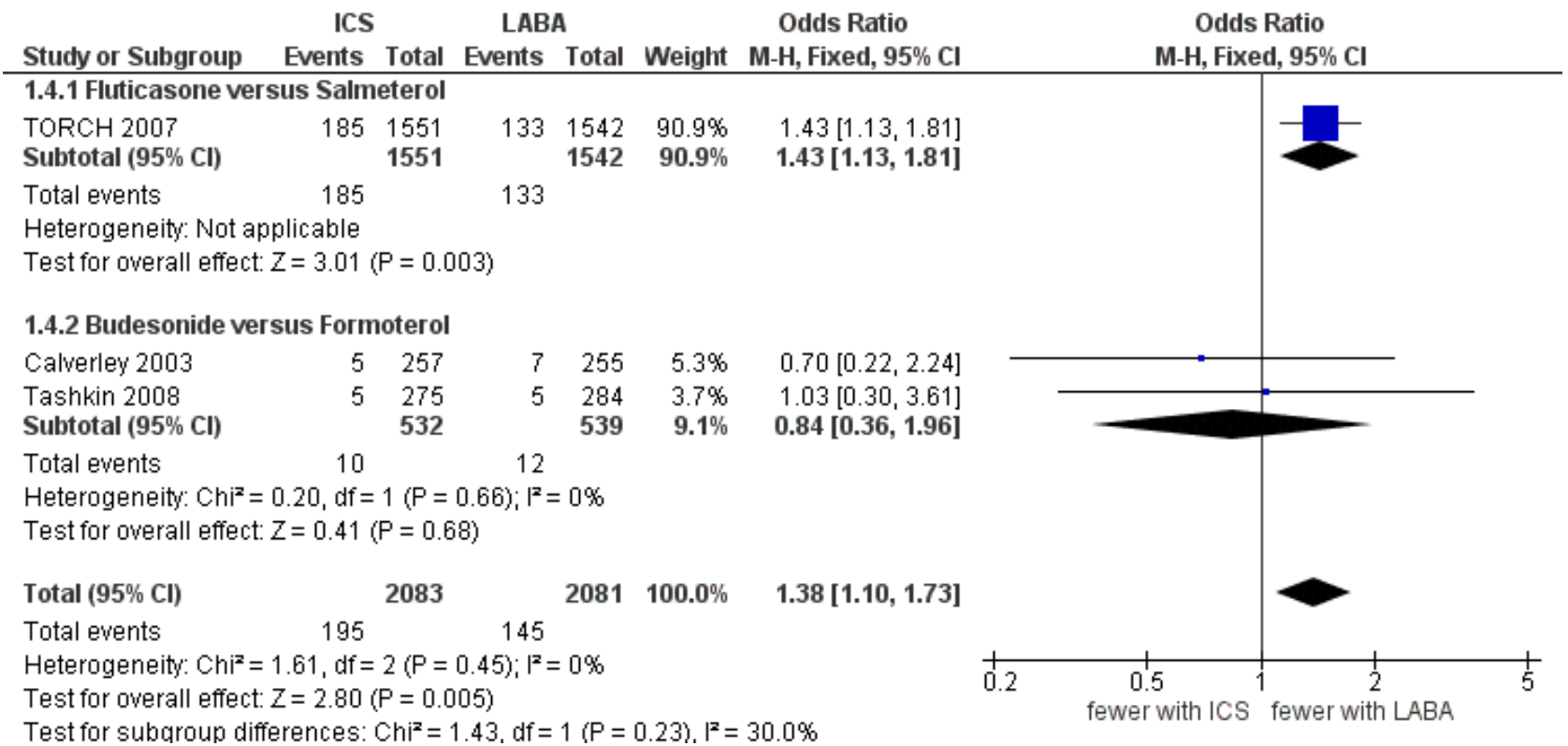


Figure 5. On LABA 7 people out of 100 had pneumonia (adverse event) over 2.4 years, compared to 9 (95\% Cl 8 to 12 ) out of 100 for the ICS group. The NNT(H) for one extra person to suffer pneumonia on ICS was 42 (95\% Cl: 155 to 23 ).

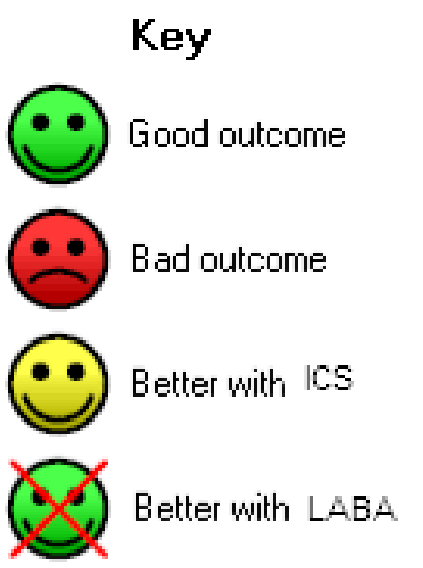

Five of the included studies (5086 participants) classified pneumonia as a serious adverse event (Mahler 2002; Hanania 2003; TRISTAN 2003; TORCH 2007; Tashkin 2008). A separate analysis was conducted for these studies as the distinction between adverse event and serious adverse event classification of pneumonia was unclear. Of these studies, four compared fluticasone versus salmeterol and one compared budesonide versus formoterol. The pooled result was again dominated by TORCH 2007 and showed
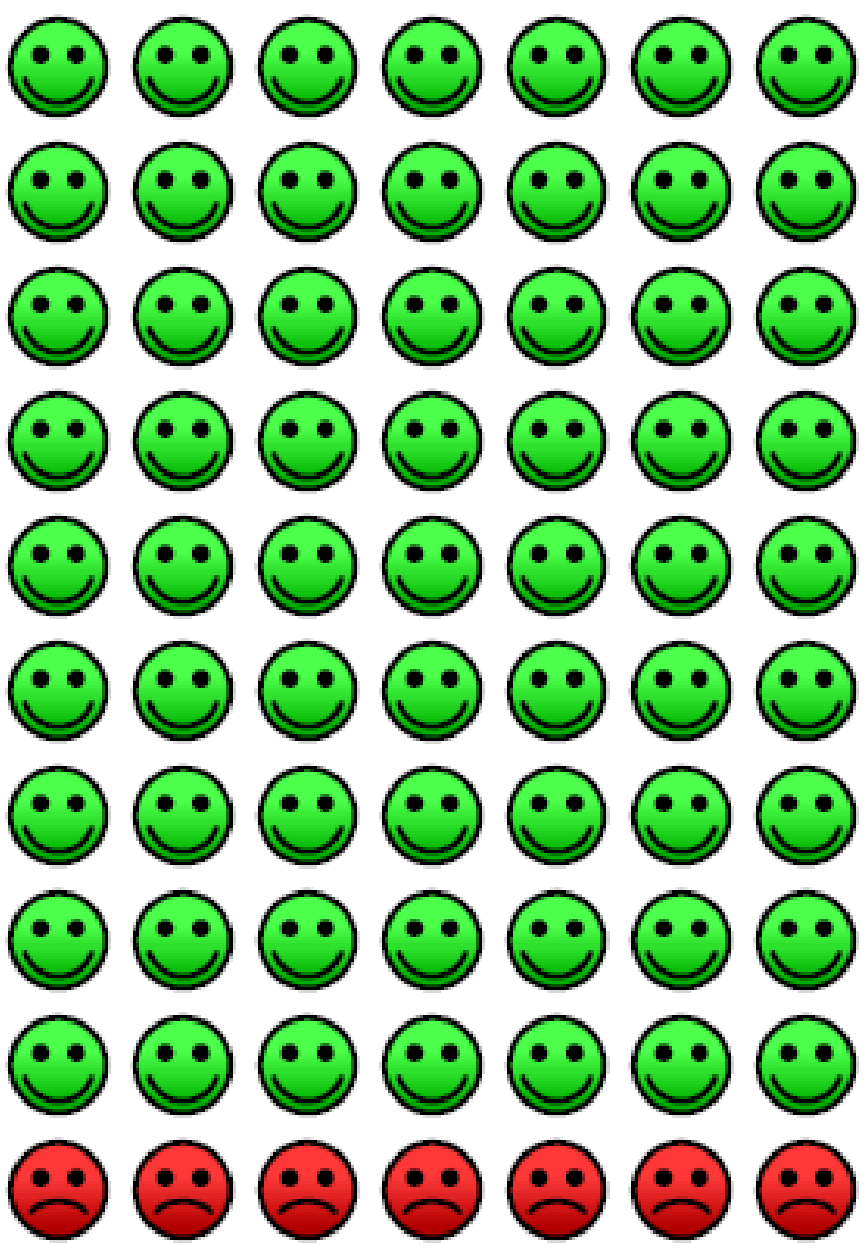

a significantly greater risk of pneumonia for patients on ICS compared to patients on LABA (Peto OR 1.48; 95\% Cl 1.13 to 1.93), see Figure 6 . There was no statistically significant difference in pneumonia, classified as a serious adverse event, between studies of $\leq 1$ year and $>1$ year of treatment $\left(\mathrm{Chi}^{2}=0.71, \mathrm{df}=1, \mathrm{P}=0.40\right)$, or between the studies using fluticasone/salmeterol and budesonide/ formoterol $\left(\mathrm{Chi}^{2}=0.42, \mathrm{df}=1, \mathrm{P}=0.51\right)$. 
Figure 6. Forest plot of comparison: 1 Inhaled corticosteroids versus long-acting beta ${ }_{2}$-agonists by ICS and LABA, outcome: 1.5 Pneumonia serious adverse event.

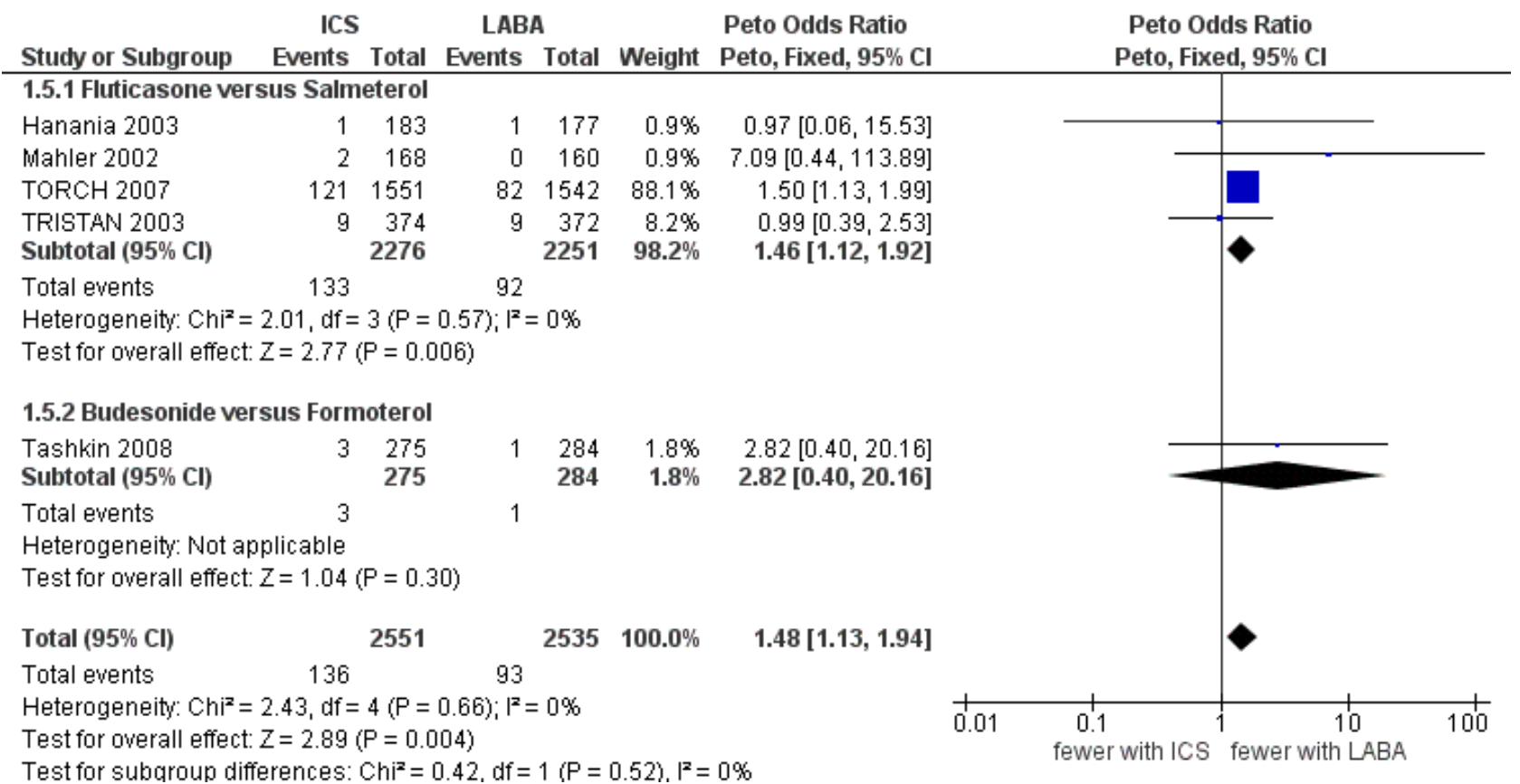

\section{Secondary outcome: mortality}

All the included studies (5997 participants in seven studies) reported the number of deaths from any cause during the treatment period. The three-year TORCH 2007 study was the only one to report mortality status for all randomised participants, including study withdrawals. The number of events was generally low except for TORCH 2007, which reported significantly more deaths among patients treated with fluticasone compared to salmeterol (Peto OR 1.23; 95\% Cl 1.01 to 1.50). The pooled result showed that there was no statistically significant difference between ICS and LABA on mortality (Peto OR 1.17; 95\% Cl 0.97 to $1.42 ; I^{2}=37 \%$ ), see Analysis 1.9 . Since $\mathrm{I}^{2}$ was greater than $20 \%$ we performed sensitivity analysis using the random-effects model (OR 0.98; $95 \% \mathrm{Cl} 0.59$ to 1.64); this model gives much less weight to TORCH 2007, which explains the reversal of direction of the treatment effect. There was heterogeneity between the two subgroups of fluticasone versus salmeterol and budesonide versus formoterol $\left(1^{2}=73 \%\right)$ but the difference was not statistically significant $\left(\mathrm{Chi}^{2}=3.64, \mathrm{df}=1, \mathrm{P}=0.06\right)$.

\section{Secondary outcome: mild exacerbations}

Data on mild exacerbations not necessitating treatment with antibiotics or oral corticosteroids were only reported by Hanania 2003 and Mahler 2002 (688 participants). There was no statistically significant difference between the fluticasone and salmeterol treatment groups, though the number of occurrences was low, leading to wide $\mathrm{Cls}$ (OR $1.51 ; 95 \% \mathrm{Cl} 0.74$ to $3.08 ; \mathrm{I}^{2}=57 \%$ ). Because of heterogeneity between the studies we performed sensitivity analysis using the random-effects model (OR 1.63; $95 \% \mathrm{Cl} 0.49$ to 5.39).

\section{Secondary outcome: measures of pulmonary function}

\section{Forced expiratory volume in one second $\left(\mathrm{FEV}_{1}\right)$}

Four studies including 1993 participants reported changes in predose FEV 1 (Mahler 2002; Hanania 2003; TRISTAN 2003; Tashkin 2008). TORCH 2007 was excluded from this analysis as the prebronchodilator $\mathrm{FEV}_{1}$ was not reported. The combined result showed a smaller increase in $\mathrm{FEV}_{1}$ for ICS than LABA when analysed with a fixed-effect model (MD -18.99; $95 \% \mathrm{Cl}-37.46$ to -0.52 ; $1^{2}$ $=24 \%)$. However, since $1^{2}$ was greater than $20 \%$ between the studies we performed a sensitivity analysis. When analysed with a random-effects model the difference in increase in $\mathrm{FEV}_{1}$ was not statistically significant (MD $-17.36 ; 95 \% \mathrm{Cl}-39.54$ to 4.82 ). There was moderate heterogeneity between the subgroups, fluticasone versus salmeterol and budesonide versus formoterol $(12=48 \%)$, but this was not statistically significant $\left(\mathrm{Chi}^{2}=1.92, \mathrm{df}=1, \mathrm{P}=0.17\right)$, see Analysis 1.6.

There were also two studies (3652 participants) which reported changes in post-dose $\mathrm{FEV}_{1}$ (TORCH 2007; Tashkin 2008). There was substantial heterogeneity between the results of the two studies (12 $=98 \%$ ). TORCH 2007 showed no statistically significant difference in mean change in 30 minute post-bronchodilator $\mathrm{FEV}_{1}$ between fluticasone and salmeterol after three years of treatment (MD 5 $\mathrm{mL} ; 95 \% \mathrm{Cl}-11.46$ to 21.46). Tashkin 2008 on the other hand showed a significantly smaller improvement in 60 minute postbronchodilator $\mathrm{FEV}_{1}$ with budesonide than with formoterol after six months of treatment (MD $-140 \mathrm{~mL} ; 95 \% \mathrm{Cl}-177.24$ to -102.76 ). Because of the many substantial differences between the two studies, the results were not pooled. 


\section{Peak expiratory flow (PEF)}

Tashkin 2008 (559 participants) reported the difference in change in morning PEF between formoterol and budesonide that was not statistically significant (MD $-4.26 \mathrm{~L} / \mathrm{min} ; 95 \% \mathrm{Cl}-9.26$ to 0.74 ).

\section{Secondary outcome: quality of life}

We could extract data on changes in health-related quality of life from three studies involving 4398 participants that used the St George's Respiratory Questionnaire (SGRQ) (TRISTAN 2003; TORCH 2007; Tashkin 2008). Patients treated with ICS showed greater improvements in quality of life compared to those treated with LABA (MD - $0.74 ; 95 \% \mathrm{Cl}-1.42$ to -0.06 ). This difference was small in relation to the threshold of four units for a clinically significant difference. There was no heterogeneity between the subgroups, see Analysis 1.10.

\section{Secondary outcome: symptom scores of breathlessness and other symptom scores}

\section{Dyspnoea}

Data on changes in dyspnoea could be extracted from five of the included studies. Changes in dyspnoea over the treatment period were measured using either a 0 to 4 point validated dyspnoea scale (Calverley 2003; TRISTAN 2003; Tashkin 2008) in 2505 participants or the validated Transition Dyspnoea Index (TDI) (Mahler 2002; Hanania 2003) in 688 participants. On the TDI scale a higher score represents an improvement in perceived breathlessness, and on the 0 to 4 dyspnoea scale a higher score represents more breathlessness. There was no statistically significant difference (MD 0.03; $95 \% \mathrm{Cl}-0.02$ to 0.08 ) between ICS and LABA using the 0 to 4 point dyspnoea scale and although there was heterogeneity between the two subgroups (fluticasone versus salmeterol and budesonide versus formoterol) $(12=57 \%)$, this was not statistically significant $\left(\mathrm{Chi}^{2}=2.31, \mathrm{df}=1, \mathrm{P}=0.13\right)$ see Analysis 1.11. However, there was also moderate heterogeneity among the studies comparing budesonide and formoterol $\left(1^{2}\right.$ $=30 \%)$ and among all the included studies $(12=47 \%)$. There was no statistically significant difference between fluticasone and salmeterol treatment in studies using the TDI (Mahler 2002; Hanania 2003) in 688 participants (MD 0.26 ; $95 \% \mathrm{Cl}-0.21$ to 0.74 ). $\mathrm{Cls}$ for the comparisons were wide using either dyspnoea scale.

\section{Symptoms}

Symptom score data could be extracted from three studies including 1470 participants (Calverley 2003; Szafranski 2003; Tashkin 2008). The mean improvement in symptom score was greater with LABA than ICS (MD $0.21 ; 95 \% \mathrm{Cl} 0.06$ to 0.37 ) although there was no coherent pattern between the studies resulting in considerable heterogeneity $\left(1^{2}=62 \%\right)$. When analysed with a random-effects model there was no statistically significant difference between ICS and LABA treatment (MD 0.22; 95\% Cl -0.03 to 0.47 ).

\section{Secondary outcome: rescue medication}

Tashkin 2008 (559 participants) reported a statistically significant difference in the use of rescue medication during the treatment period that favoured formoterol (MD 0.56 puffs $/ 24 \mathrm{~h} ; 95 \% \mathrm{Cl} 0.10$ to 1.02).

\section{Secondary outcome: adverse events}

\section{All adverse events}

The number of patients suffering adverse events could be extracted from five studies including 5086 participants (Mahler 2002; Hanania 2003; TRISTAN 2003; TORCH 2007; Tashkin 2008). Patients receiving ICS had more adverse events (2122/2552) compared to those receiving LABA (2070/2537), but the difference was not statistically significant (OR $1.12 ; 95 \% \mathrm{Cl} 0.96$ to 1.30 ). There was no heterogeneity between the subgroups.

\section{Serious adverse events (non-fatal)}

Data on the number of non-fatal, serious adverse events could be obtained from three of the included studies (Calverley 2003; Szafranski 2003; Tashkin 2008) (1470 participants). These three studies all compared the risk of serious adverse events associated with budesonide treatment versus formoterol, which was not statistically significant (OR $1.01 ; 95 \% \mathrm{Cl} 0.77$ to 1.31 ). Data on the number of participants experiencing one or more non-fatal, serious adverse events were obtained from a further three of the included studies (Mahler 2002; Hanania 2003; TRISTAN 2003) (1434 participants). These studies all compared fluticasone versus salmeterol. There was considerable heterogeneity among the studies $(12=54 \%)$, and there was no statistically significant difference between the treatments (OR $0.93 ; 95 \% \mathrm{Cl} 0.67$ to 1.31 ). This was consistent when analysed with a random-effects model (OR 1.17; $95 \% \mathrm{Cl} 0.60$ to 2.28) (Analysis 1.15).

\section{Secondary outcome: all cause hospitalisations}

None of the included studies reported the number of patients admitted to hospital for any cause.

\section{Secondary outcome: withdrawals}

All seven of the included studies reported the number of participant withdrawals from each treatment arm. Overall there was no statistically significant difference in the number of withdrawals between patients on ICS and LABA (OR 1.02; 95\% Cl 0.92 to $1.14 ; 1^{2}=29 \%$ ) (Analysis 1.16). Subgroup analysis showed no statistically significant differences between fluticasone versus salmeterol (OR $1.05 ; 95 \% \mathrm{Cl} 0.92$ to 1.18 ) and budesonide versus formoterol (OR $0.96 ; 95 \% \mathrm{Cl} 0.76$ to 1.20 ). However, there was moderate heterogeneity among the studies comparing fluticasone and salmeterol $\left(I^{2}=58 \%\right)$.

\section{DISCUSSION}

\section{Summary of main results}

This systematic review set out to investigate the relative effects of inhaled corticosteroids and long-acting beta ${ }_{2}$-agonists on clinical endpoints in patients with stable COPD using direct comparisons from randomised trials. Seven randomised, active-control, doubleblind trials involving 5997 participants were identified. The results of the review were dominated by the largest study, TORCH 2007, for many outcomes (exacerbations, pneumonia, mortality, healthrelated quality of life and withdrawals).

The review showed no statistically significant differences between ICS and LABA in the number of patients experiencing exacerbations or the number of exacerbation per patient year (rate ratio). This result was accompanied by narrow confidence intervals, which 
suggests that there may not be a big difference in exacerbation rates between ICS and LABA. Given the pharmacological differences between the drugs, it seems reasonable to conclude that they are exerting different benefits (albeit of seemingly equal clinical importance) and this endorses the assumption that exacerbations are complex in terms of their pathophysiology. Data on exacerbations leading to hospitalisation were only reported by TORCH 2007 and also showed no statistically significant difference between ICS and LABA. Exacerbation rates are often higher in patients who withdraw from a study before completion (Keene 2008) and this could suggest that the rates used in this review underestimate population exacerbation frequencies. However, this would only represent potential analytical bias in the presence of differential dropout rates, and this study has shown parity between ICS and LABA withdrawals.

The risk of pneumonia was significantly greater for patients on ICS than patients on LABA, whether classified as an adverse event (OR $1.38 ; 95 \% \mathrm{Cl} 1.10$ to 1.73 ) or a serious adverse event (Peto OR 1.48; $95 \% \mathrm{Cl} 1.13$ to 1.94). The increased incidence of pneumonia with ICS compared to LABA appears independent of study length. However, it should be noted that event rates were very low (3\% or less) in all studies with the exception of TORCH 2007, the largest and longest of all the included studies.

Differences in mortality between ICS and LABA were not statistically significant (Peto OR 1.17; 95\% Cl 0.97 to 1.42). However, TORCH 2007 was the only study to record mortality status for all randomised participants, including withdrawals, and it recorded significantly more deaths on the ICS fluticasone compared to the LABA salmeterol (OR $1.23 ; 95 \% \mathrm{Cl} 1.01$ to 1.50 ). It should be noted that very low event rates in the majority of studies may be due, in part, to follow-up limited to patients remaining in the study, and the study duration. Conversely, interpretation of mortality data is complicated by the tendency for patients who withdraw to then be given the other active study therapies, for example patients withdrawing from the LABA arm are prescribed ICS, though this is likely to reduce differences between groups rather than to enhance them.

Treatment with ICS led to a smaller improvement in lung function (pre-bronchodilator $\mathrm{FEV}_{1}$ ) compared to LABA, although the difference was relatively small (MD $-18.99 \mathrm{~mL} ; 95 \% \mathrm{Cl}-37.46$ to -0.52). Post-dose FEV1 was reported in two studies and gave very different results with high heterogeneity, and there were too many differences between the studies to be able to pool the outcome. The change in health-related quality of life was also significantly different between the treatment arms but with this outcome improvements were greater with ICS treatment than with LABA (SGRQ MD $-0.74 ; 95 \% \mathrm{Cl}-1.42$ to -0.06 ). However, the differences in health-related quality of life were small in comparison to the threshold for a clinically important difference (defined as a change of four units). Improvements in quality of life in favour of ICS may support the idea that the drug exerts its benefits not just in terms of alleviating or abrogating lung function impairment (noting that LABA also improves lung function). Given the possibility that COPD is a systemic disease, it may be that drug effects on airways inflammation have wider consequences, that is reductions in systemic consequences of airways inflammation. There were no significant differences for hospitalisations due to exacerbations, mild exacerbations, peak expiratory flow, dyspnoea, symptoms scores, rescue medication, adverse events, all cause hospitalisations, and withdrawals from studies.

\section{Overall completeness and applicability of evidence}

- This review has provided evidence to suggest that differences in exacerbation rates between COPD patients treated with ICS and those treated with LABA are unlikely.

- High withdrawal rates compared to low mortality rates introduces considerable uncertainty in the analysis of mortality from the smaller, shorter studies. However, TORCH 2007, which was the only study with complete mortality data, reported higher mortality with ICS therapy compared to LABA therapy.

- The size and length of TORCH 2007 lends substantial weight to evidence for an increased risk of pneumonia with ICS treatment compared to LABA treatment. However, event rates across the remaining studies were low and the results should therefore be interpreted with caution.

- The indirect comparisons between the trials comparing budesonide with formoterol and fluticasone with salmeterol do not allow any conclusions to be drawn about the relative efficacy and safety of budesonide and fluticasone or formoterol and salmeterol.

- Data synthesis was limited by the lack of common data for several outcomes. The definition of change and impact differed substantially with studies using: a) different outcome measures, e.g. pre-bronchodilator or post-bronchodilator FEV1, b) different units of analysis, e.g. $\mathrm{mL}$ or $\%$ change from baseline, c) no exact measures of variability for differences between treatments, e.g. no $\mathrm{Cl}$, no exact $\mathrm{P}$ value.

\section{Quality of the evidence}

The included studies were generally of good quality, free from selective reporting of results, and all but one of the studies used intention-to-treat data analysis to control for the relatively high withdrawal rates, which are common in long ( $\geq$ six-month) COPD trials. However, because of the high number of withdrawals in the included studies, the results for the dichotomous outcomes with relatively few events (such as mortality, pneumonia and serious adverse events) are less reliable when the withdrawals have not been followed up, and must be interpreted with caution.

\section{Potential biases in the review process}

Several of the studies did not report on the statistical variance of the difference between the ICS and LABA arms as these were not the primary issues in those studies. We were able to calculate these variances from exact $P$ values or confidence intervals (see Appendix 1). However, for some of the outcomes several studies only provided approximate $P$ values (see Table 1 ) and as we were not able to obtain further information from the authors data for these outcomes could not be used in this review.

\section{Agreements and disagreements with other studies or reviews}

Several systematic reviews have tried to clarify the contribution of ICS and LABA to the benefits and risks of the combination inhalers in COPD. Treatment with ICS and LABA combination inhalers has been shown to significantly reduce exacerbation rates in COPD patients compared to placebo (rate ratio $0.74 ; 95 \% \mathrm{Cl} 0.7$ to 0.8 ) (Nannini 2007a). In comparison to placebo, combination therapy 
also significantly reduced all cause mortality (primarily based on TORCH 2007) (OR 0.79; $95 \% \mathrm{Cl}, 0.65$ to 0.96 ); improved healthrelated quality of life, symptoms and lung function; but increased the risk of pneumonia (OR 1.83; 95\% Cl 1.51 to 2.21) (Nannini 2007a). Systematic reviews comparing ICS treatment with placebo have shown that ICS reduced the occurrence of exacerbations (risk ratio (RR) 0.82; 95\% Cl 0.73 to 0.92) (Agarwal 2010), slowed the decline in health-related quality of life (MD -1.22 units/year; 95\% $\mathrm{Cl}-1.83$ to -0.60$)$ and improved $\mathrm{FEV}_{1}$ after two to six months of treatment (Yang 2007). Although long-term use of ICS (longer than six months) did not reduce the rate of decline in FEV 1 (MD 5.80 $\mathrm{mL} /$ year with ICS; $95 \% \mathrm{Cl}-0.28$ to 11.88 ), it was not associated with a higher mortality rate compared to placebo (OR $0.98 ; 95 \%$ $\mathrm{Cl} 0.83$ to 1.16) (Yang 2007). Neither of these reviews looked at adverse events, including pneumonia. Compared to placebo, LABA treatment has also been shown to reduce exacerbations (RR 0.78 ; $95 \% \mathrm{Cl} 0.67$ to 0.91 ) and improve health-related quality of life (MD $-3.26 ; 95 \% \mathrm{Cl}-4.57$ to -1.96$)$ without a significant effect on mortality (RR 0.95; 95\% Cl 0.80 to 1.14) (Appleton 2006; Rodrigo 2008). The reviews of placebo-controlled studies have shown benefits for both monotherapies without an increased risk of mortality. Comparing the effects of combination inhaler to those of its components has shown that all cause mortality is lower with combined treatment than with ICS alone (OR $0.77 ; 95 \% \mathrm{Cl} 0.63$ to 0.94) (Nannini 2007), whereas there was no significant difference in mortality between combined inhalers and LABA alone (RR 0.90; 95\% Cl 0.76 to 1.06) (Nannini 2007b; Rodrigo 2009). Quality of life and lung function favour combination treatment over both monotherapies (Nannini 2007; Nannini 2007b; Rodrigo 2009). Combination therapy also significantly reduced exacerbation rates compared to the individual monotherapies: ICS/LABA versus ICS (rate ratio 0.91; $95 \% \mathrm{Cl} 0.85$ to 0.97 ) (Nannini 2007), ICS/LABA versus LABA (rate ratio $0.82 ; 95 \% \mathrm{Cl} 0.78$ to 0.88 ) (Nannini 2007b). A recent review found that combination inhalers did not significantly decrease the number of severe exacerbations (RR $0.91 ; 95 \% \mathrm{Cl} 0.82$ to 1.01 ) but did decrease the number of moderate exacerbations (RR 0.84; $95 \% \mathrm{Cl} 0.74$ to 0.96 ) (Rodrigo 2009). No statistically significant difference in the odds of pneumonia has been shown between combination inhaler and ICS alone (OR 1.13; $95 \% \mathrm{Cl} 0.92$ to 1.38) (Nannini 2007), whereas pneumonia occurs more commonly with combined inhalers than with LABA alone (OR 1.58; 95\% Cl 1.32 to 1.88 (Nannini 2007b); RR $1.63 ; 95 \% \mathrm{Cl} 1.35$ to 1.98 (Rodrigo 2009)). A recent meta analysis including 24 randomised trials (16 fluticasone trials, seven budesonide trials and one mometasone trial) showed a significantly increased risk of pneumonia with ICS (RR 1.56; 95\% Cl 1.40 to 1.74; $P=0.0001$ ) (Singh 2010). The elevated risk remained consistent irrespective of whether the ICS/ LABA combination inhaler was compared to LABA or ICS to placebo (Singh 2010).

In summary:

- both ICS and LABA may contribute to a decrease in exacerbation rates but according to the results from this review there is not a large difference between them;

- although ICS therapy benefits COPD patients, it also increases the risk of pneumonia;
- the effect of ICS and LABA on mortality is more complicated. According to Yang 2007 and Rodrigo 2008 there is not enough evidence to say that ICS or LABA influences all cause mortality on its own. However, in combination they seem to cause a reduction in mortality both compared to placebo (Nannini 2007a) and to ICS alone (Nannini 2007) but not compared to LABA (Nannini 2007b; Rodrigo 2009). This review supports the view that there is insufficient evidence for the impact of LABA and ICS on mortality and the differential impact of ICS and LABA on mortality remains unclear. Our review showed no overall difference in mortality rates between the monotherapies but the study with the most reliable mortality data (TORCH 2007) showed lower rates for patients receiving LABA therapy;

- according to this review LABA therapy is associated with small improvements in $\mathrm{FEV}_{1}$ compared to ICS, which is consistent with the results from the above reviews; and

- both ICS and LABA increase the patient's quality of life but ICS therapy is associated with slightly larger improvements.

\section{AUTHORS' CONCLUSIONS}

\section{Implications for practice}

The benefits of ICS therapy for COPD patients may be similar to those of LABA, but there is potentially an increased incidence of pneumonia. These data support both national and international guidelines stating that the choice of drugs should take into account the person's symptomatic response, the drug's potential to reduce exacerbations and side effects (GOLD 2010; NICE 2010).

\section{Implications for research}

Additional work is required in assessing the risks and benefits of budesonide/formoterol combination inhalers. Potential class effects between fluticasone and budesonide are still unknown as are the influence of high and low doses on benefits and risks for both drugs. The lack of key standardised outcomes is an impediment to the synthesis of trial data for systematic reviews. We strongly recommend international consensus on the identification and definition of key common outcomes, for example change from baseline in pre-bronchodilator $\mathrm{FEV}_{1}(\mathrm{~mL})$, change from baseline in health-related quality of life, and complete mortality data for all randomised participants including study withdrawals.

\section{ACKNOWLEDGEMENTS}

We would like to thank staff at the Cochrane Airways Group for their excellent support and encouragement during the preparation of this review. We would also like to thank Toby Lasserson for his support during his time as managing editor of the Airways group. We would also like thank our partners for their tolerance, endurance and support during the production of this review.

CRG Funding Acknowledgement: The National Institute for Health Research (NIHR) is the largest single funder of the Cochrane Airways Group.

Disclaimer: The views and opinions expressed therein are those of the authors and do not necessarily reflect those of the NIHR, NHS or the Department of Health. 


\section{REFERE N CES}

\section{References to studies included in this review}

\section{Calverley 2003 \{published and unpublished data\}}

Borgstrom L, Asking L, Olsson H, Peterson S. Lack of interaction between disease severity and therapeutic response with budesonide/formoterol in a single inhaler [Abstract]. American Thoracic Society 100th International Conference, May 21-26. 2004:C22 [Poster 505].

* Calverley PM, Bonsawat W, Cseke Z, Zhong N, Peterson S, Olsson $\mathrm{H}$. Maintenance therapy with budesonide and formoterol in chronic obstructive pulmonary disease. European Respiratory Journal 2003;22(6):912-9.

Calverley PMA. Effect of budesonide/formoterol on severe exacerbations and lung function in moderate to severe COPD. Thorax 2002;57 Suppl III:iii44.

Calverley PMA, Cseke Z, Peterson S. Budesonide/formoterol reduces the use of oral corticosteroids in the treatment of COPD [Abstract]. European Respiratory Journal 2003;22 Suppl 45:P436.

Calverley PMA, Kuna P, Olsson H. COPD exacerbations are reduced by budesonide/formoterol in a single inhaler [Abstract]. European Respiratory Journal 2003;22 Suppl 45:P1587.

Calverley PMA, Olsson H, Symbicort International COPD Study Group. Budesonide/formoterol ina single inhaler sustains improvements in lung function over 12 months compared with monocomponents and placebo in patients with COPD [abstract]. American Thoracic Society 99th International Conference. 2003:B024 [Poster 418].

Calverley PMA, Peterson S. Combining budesonide/formoterol in a single inhale reduces exacerbation frequency in COPD [abstract]. American Thoracic Society 99th International Conference. 2003:D092 [Poster 211].

Calverley PMA, Stahl E, Jones PW. Budesonide/formoterol improves the general health status of patients with COPD [Abstract]. American Thoracic Society 2005 International Conference; May 20-25; San Diego, California. 2005:B93 [Poster 303].

Calverley PMA, Szafranski W, Andersson A. Budesonide/ formoterol is a well-tolerated long term maintenance therapy for COPD. European Respiratory Journal 2005;26 Suppl 49:Poster 1917.

Calverley PMA, Thompson NC, Olsson H. Budesonide/ formoterol in a single inhaler sustains lung function improvements in COPD [Abstract]. European Respiratory Journal 2003;22 Suppl 45:P435

Halpin D, Stahl E, Lundback B, Anderson F, Peterson S. Treatment costs and number needed to treat (NNT) with budesonide/formoterol to avoid one exacerbation of COPD [Abstract]. American Thoracic Society 100th International Conference, May 21-26. 2004:D22 [Poster 525].
Halpin DMG, Larsson T, Calverley PMA. How many patients with COPD must be treated with budesonide/formoterol compared with formoterol alone to avoid 1 day of oral steroid use? [Abstract]. American Thoracic Society 2005 International Conference; May 20-25; San Diego, California. 2005:B93 [Poster 314].

Jones PW, Stahl E. Budesonide/formoterol in a single inhaler improves health status in patients with COPD [abstract]. American Thoracic Society 99th International Conference. 2003:B024 [Poster 419].

Jones PW, Ståhl E. Budesonide /formoterol sustains clinically relevant improvements in health status in COPD [Abstract]. European Respiratory Journal 2005;26 Suppl 49:Abstract 1352.

Jones PW, Ståhl E. Reducing exacerbations leads to a better health-related quality of life in patients with COPD. 13th ERS Annual Congress, 27th September, 2003, Vienna. 2003:P1586.

Lofdahl CG. Reducing the impact of COPD exacerbations: Clinical efficacy of budesonide/formoterol. European Respiratory Review 2004;13(88):14-21.

Lofdahl CG, Andreasson E, Svensson K, Ericsson A. Budesonide/ formoterol in a single inhaler improves health status in patients with COPD without increasing healthcare costs [Abstract]. European Respiratory Journal 2003;22 Suppl 45:P433.

Lofdahl CG, Ericsson A, Svensson K, Andreasson E. Cost effectiveness of budesonide/formoterol in a single inhaler for COPD compared with each monocomponent used alone. Pharmacoeconomics 2005;23(4):365-75.

\section{Hanania 2003 \{published and unpublished data\}}

* Hanania NA, Darken P, Horstman D, Reisner C, Lee B, Davis S, et al. The efficacy and safety of fluticasone propionate (250 micro g)/salmeterol (50 micro g) combined in the diskus inhaler for the treatment of COPD. Chest 2003;124(3):834-43.

Hanania NA, Knobil K, Watkins M, Wire P, Yates J, Darken P. Salmeterol and fluticasone propionate therapy administered by a single diskus in patients with COPD. Chest. 2002:S129.

Hanania NA, Ramsdell J, Payne K, Davis S, Horstman D, Lee B, et al. Improvements in airflow and dyspnea in COPD patients following 24 weeks treatment with salmeterol $50 \mathrm{mcg}$ and fluticasone propionate $250 \mathrm{mcg}$ alone or in combination via the diskus. American Journal of Respiratory and Critical Care Medicine 2001;163 Suppl(5):A279.

Horstman D, Darken P, Davis S, Lee B. Improvements in FEV1 and symptoms in poorly reversible COPD patients following treatment with salmeterol $50 \mathrm{mcg} /$ fluticasone propionate $250 \mathrm{mcg}$ combination [Abstract]. European Respiratory Journal 2003;22 Suppl 45:P434.

Mahler DA, Darken P, Brown CP, Knobil K. Predicting lung function responses to combination therapy in chronic obstructive pulmonary disease (COPD) [Abstract]. National COPD Conference; Arlington, Virginia. 2003:Abstract 1081. 
Mahler DA, Darken P, Brown CP, Knobil K. Predicting lung function responses to salmeterol/fluticasone propionate combination therapy in COPD [Abstract]. European Respiratory Journal 2003;22 Suppl 45:P429.

SFCA3007. A randomized, double-blind, placebo-controlled, parallel-group trial evaluating the safety and efficacy of the DISKUS formulations of Salmeterol (SAL) 50mcg BID and Fluticasone Propionate (FP) $250 \mathrm{mcg}$ BID individually and in combination as Salmeterol $50 \mathrm{mcg} /$ Fluticasone Propionate $250 \mathrm{mcg}$ BID (SFC 50/250) compared to placebo in COPD subjects. GlaxoSmithKline Clinical Trials Register (http:ctr.gsk.co.uk) 2005.

Spencer M, Wire P, Lee B, Chang CN, Darken P, Horstman D. Patients with COPD using salmeterol/fluticasone propionate combination therapy experience improved quality of life. European Respiratory Journal 2003;22 Suppl 45:51s.

Spencer MD, Karia N, Anderson J. The clinical significance of treatment benefits with the salmeterol/fluticasone propionate $50 / 500 \mathrm{mcg}$ combination in COPD. European Respiratory Journal 2004;24 Suppl 48:290s.

\section{Mahler 2002 \{published and unpublished data\}}

Mahler DA, Darken P, Brown CP, Knobil K. Predicting lung function responses to combination therapy in chronic obstructive pulmonary disease (COPD). http:// www.abstracts2view.com 2003.

* Mahler DA, Wire P, Horstman D, Chang CN, Yates J, Fischer T, et al. Effectiveness of fluticasone propionate and salmeterol combination delivered via the diskus device in the treatment of chronic obstructive pulmonary disease. American Journal of Respiratory Critical Care Medicine 2002;166(8):1084-91.

SFCA3006. A randomized, double-blind, placebo-controlled, parallel-group trial evaluating the safety and efficacy of the DISKUS formulations of Salmeterol (SAL) $50 \mathrm{mcg}$ BID and Fluticasone Propionate (FP) $500 \mathrm{mcg}$ BID individually and in combination as Salmeterol $50 \mathrm{mcg} /$ Fluticasone Propionate 500mcg BID (SFC 50/500) compared to placebo in COPD subjects. GlaxoSmithKline Clinical Trials Register (http:ctr.gsk.co.uk) 2005.

Spencer M, Wire P, Lee B, Chang CN, Darken P, Horstman D. Patients with COPD using salmeterol/fluticasone propionate combination therapy experience improved quality of life. European Respiratory Journal 2003;22 Suppl 45:51.

Spencer MD, Anderson JA. Salmeterol/fluticasone combination produces clinically important benefits in dyspnea and fatigue [Abstract]. American Thoracic Society 2005 International Conference; May 20-25; San Diego, California; 2005. 2005:B93 [Poster 308].

Spencer MD, Karia N, Anderson J. The clinical significance of treatment benefits with the salmeterol/fluticasone propionate $50 / 500 \mathrm{mcg}$ combination in COPD. European Respiratory Journal 2004;24 Suppl 48:290.

\section{Szafranski 2003 \{published and unpublished data\}}

Anderson P. Budesonide/formoterol in a single inhaler (Symbicort) provides early and sustained improvement in lung function in moderate to severe COPD [Abstract]. Thorax 2002;57 Suppl iii:43.

Borgstrom L, Asking L, Olsson H, Peterson S. Lack of interaction between disease severity and therapeutic response with budesonide/formoterol in a single inhaler [Abstract]. American Thoracic Society 100th International Conference, May 21-26. 2004:C22 [Poster 505].

Calverley P, Pauwels R, Lofdahl CG, Svensson K, Higenbottam T, et al. Relationship between respiratory symptoms and medical treatment in exacerbations of COPD. European Respiratory Journal 2005;26(3):406-13.

Calverley PMA. Effect of budesonide/formoterol on severe exacerbations and lung function in moderate to severe COPD. Thorax. BTS Winter meeting 2002:S145.

Calverley PMA, Szafranski W, Andersson A. Budesonide/ formoterol is a well-tolerated long term maintenance therapy for COPD. European Respiratory Journal 2005;26 Suppl 49:Poster 1917.

Calverley PMA, Thompson NC, Olsson H. Budesonide/ formoterol in a single inhaler sustains lung function improvements in COPD [Abstract]. European Respiratory Journal 2003;22 Suppl 45:P435.

Campbell LM, Szafranski W. Budesonide/formoterol in a single inhaler (Symbicort) provides sustained relief from symptoms in moderate to severe COPD. Thorax. BTS Winter meeting 2002:S143.

Campell LW, Szafranski W. Budesonide/formoterol in a single inhaler (Symbicort) reduces severe exacerbations in patients with moderate-severe COPD. Thorax. BTS Winter meeting 2002:S141.

Dahl R, Cukier A, Olsson H. Budesonide/formoterol in a single inhaler reduces severe and mild exacerbations in patients with moderate to severe COPD. European Respiratory Journal 2002;20 Suppl 38:242 [P1575].

Egede F, Menga G. Budesonide/formoterol in a single inhaler provides sustained relief from symptoms and night-time awakenings in moderate-severe COPD: results from symptoms and night-time awakenings in moderate to severe COPD: results from a 1-year study. European Respiratory Journal 2002;20 Suppl 38:242 [P1574].

Halpin D, Stahl E, Lundback B, Anderson F, Peterson S. Treatment costs and number needed to treat (NNT) with budesonide/formoterol to avoid one exacerbation of COPD [Abstract]. American Thoracic Society 100th International Conference, May 21-26. 2004:D22 [Poster 525].

Jones PW, Stahl E, Svensson K. Improvement in health status in patients with moderate to severe COPD after treatment with budesonide/formoterol in a single inhaler. European Respiratory Journal 2002;20 Suppl 38:250 [P1613]. 
Korsgaard J, Sansores R. Budesonide/formoterol (single inhaler) provides sustained relief from shortness of breath and chest tightness in a 1-year study of patients with moderate to severe COPD. European Respiratory Journal 2002;20 Suppl 38:242 [P1577].

Lange P, Saenz C. Budesonide/formoterol in a single inhaler is well tolerated in patients with moderate to severe COPD: results of a 1 year study. European Respiratory Journal 2002;20 Suppl 38:242 [P1573].

Lofdahl CG. Reducing the impact of COPD exacerbations: Clinical efficacy of budesonide/formoterol. European Respiratory Review 2004;13(88):14-21.

Milanowski J, Nahabedian S. Budesonide/formoterol in a single inhaler acts rapidly to improve lung function and relieve symptoms in patients with moderate to severe COPD. European Respiratory Journal 2002;20 Suppl 38:242 [P1576].

* Szafranski W, Cukier A, Ramirez A, Menga G, Sansores R, Nahabedian S, et al. Efficacy and safety of budesonide/ formoterol in the management of chronic obstructive pulmonary disease. European Respiratory Journal 2003;21(1):74-81.

\section{Tashkin 2008 \{unpublished data only\}}

AstraZeneca. A 6-month double-blind, double-dummy, randomized, parallel group, multicenter efficacy \& safety study of SYMBICORT ${ }^{\circledR}$ pMDI 2 x 160/4.5 $\mu \mathrm{g} \& 80 / 4.5 \mu \mathrm{g}$ bid compared to formoterol TBH, budesonide pMDI (\& the combination) \& placebo in COPD Patients (SHINE) (study number D589900002). www.astrazenecaclinicaltrials.com 2007.

Bleecker ER, Meyers DA, Bailey WC, Sims AM, Bujac SR, Goldman M, et al. Effect Of ß2-Adrenergic Receptor Gene Polymorphism Gly16Arg On Response To Budesonide/ Formoterol Pressurized Metered-Dose Inhaler In Chronic Obstructive Pulmonary Disease [Abstract]. American Journal of Respiratory and Critical Care Medicine 2011; Vol. 183, issue Meeting Abstracts:A4086.

* Tashkin DP, Rennard SI, Martin P, Ramachandran S, Martin UJ, Silkoff PE, et al. Efficacy and safety of budesonide and formoterol in one pressurized metered-dose inhaler in patients with moderate to very severe chronic obstructive pulmonary disease: results of a 6-month randomized clinical trial. Drugs. 2008/09/10 2008; Vol. 68, issue 14:1975-2000. [0012-6667: (Print)]

\section{TORCH 2007 \{published and unpublished data\}}

Briggs AH, GHA, L-OG, SM, CPMA, JPW, et al. Is treatment with ICS and LABA cost-effective for COPD? Multinational economic analysis of the TORCH study. European Respiratory Journal 2010; Vol. 35, issue 3:532-9.

Calverley P, Celli B, Anderson JA, Ferguson GT, Jenkins C, Jones PW, et al. The TOwards a Revolution in COPD Health (TORCH) study: salmeterol/fluticasone propionate improves survival in COPD over three years. Respirology 2006;11 Suppl 5:A149.
Calverley PM, AJA, CB, FGT, JC, JPW, et al. Cardiovascular events in patients with COPD: TORCH study results. Thorax 2010; Vol. 65 , issue 8:719-25.

Calverley PM, Celli B, Anderson JA, Ferguson GT, Jenkins C, Jones PW, et al. The towards a revolution in COPD health (TORCH) study: fluticasone propionate/salmeterol improves survival in COPD over three years. Chest 2006;130(4):122s.

* Calverley PMA, Anderson JA, Celli B, Ferguson GT, Jenkins C, Jones PW, et al. Salmeterol and fluticasone propionate and survival in chronic obstructive pulmonary disease. New England Journal of Medicine 2007;356(8):775-89.

Calverley PMA, Celli B, Andersen JA, Ferguson GT, Jenkins C, Jones PW, et al. The TORCH (towards a revolution in COPD health) study salmeterol/fluticasone propionate (SFC) improves survival in COPD over three years. European Respiratory Journal 2006;28 Suppl 50:34.

Calverley PMA, Celli B, Ferguson G, Jenkins C, Jones PW, Pride NB, et al. Baseline characteristics of the first 5,000 COPD patients enrolled in the TORCH survival study. European Respiratory Journal 2003;22 Suppl 45:578s.

Celli B, Calverley PM, Anderson JA, Ferguson GT, Jenkins C, Jones $\mathrm{P}$, et al. The TOwards a Revolution in COPD HEalth (TORCH) Study: salmeterol/fluticasone propionate reduces the rate of exacerbations over three years. Respirology 2006;11 Suppl 5:A140.

Celli B, Calverley PMA, Anderson JA, Ferguson GT, Jenkins C, Jones PW, et al. The TORCH (TOwards a Revolution in COPD Health) study: salmeterol/fluticasone propionate (SFC) improves health status, reduces exacerbations and improves lung function over three years. European Respiratory Journal 2006;28 Suppl 50:34s.

Celli B, Emmett A, Crater G, Kalberg C. Fluticasone propionate/ salmeterol (FSC) improves the inspiratory to total lung capacity ratio (IC/TLC) and exercise endurance time in patients with COPD.. Proceeedings of the American Thoracic Society. 2006:A320 (Poster 323).

Celli B, Vestbo J, Jenkins CR, Jones PW, Ferguson GT, Calverley PMA, et al. Sex differences in mortality and clinical expressions of patients with chronic obstructive pulmonary disease: The TORCH experience. American Journal of Respiratory and Critical Care Medicine 2011; Vol. 183, issue 3:317-22.

Celli D, Emmett A, Crater G, Kalberg C. Salmeterol/fluticasone propionate (SFC) improves the inspiratory to total lung capacity ratio (IC/TLC) and exercise endurance time in patients with COPD. European Respiratory Journal 2006;28 Suppl 50:764 [4395].

Corhay JL, Louis R. Clinical study of the month: the TORCH study (TOwards a Revolution in COPD Health) [L'étude clinique du mois. L'étude TORCH (TOwards a Revolution in COPD Health): vers une revolution de la santé des patients souffrant de BPCO]. Revue Medicale de Liege 2007;62(4):230-4. 
Ferguson GT, CPM, AJA, JCR, CB, et al. Prevalence and progression of osteoporosis in patients with COPD results from the Towards a Revolution in COPD Health Study. Chest 2009; Vol. 136, issue 6:1456-65. [0012-3692]

Ferguson GT, Calverley PM, Anderson JA, Celli B, Jenkins C, Jones PW, et al. The towards a revolution in COPD health (TORCH) study: fluticasone propionate/salmeterol is well tolerated in patients with COPD over 3 years. Chest 2006;130(4):178s.

Ferguson GT, Calverley PMA, Anderson JA, et al. The TORCH (TOwards a Revolution in COPD Health) study: salmeterol/ fluticasone propionate (SFC) improves survival in COPD over three years. European Respiratory Journal 2006;28 Suppl 50:34s.

Jenkins CR, Calverley PMA, Celli B, Ferguson G, Jones PW, Pride $\mathrm{N}$, et al. Seasonal patterns of exacerbation rates in the TORCH survival study. http://www.abstracts2view.com 2007:A839.

Jones PW, Calverley P, Celli B, Ferguson G, Jenkins C, Pride N. Trans-Regional Validity of the SGRQ in the TORCH Survival Study. http://www.abstracts2view.com 2007:A122.

Jones PW, Calverley PM, Celli B, Anderson JA, Ferguson GT, Jenkins $C$, et al. The towards study a revolution in COPD health (TORCH) study: fluticasone propionate/salmeterol improves and sustains health status in COPD over 3 years. Chest 2006;130(4):177s.

Keene ON, VJ, AJA, CPMA, CB, FGT, et al. Methods for therapeutic trials in COPD: Lessons from the TORCH trial. European Respiratory Journal 2009; Vol. 34, issue 5:1018-23.

McDonough C, BAR. TORCH study results: pharmacotherapy reduces lung function decline in patients with chronic obstructive pulmonary disease. Hospital Practice 2010; Vol. 38, issue 2:92-3.

McGarvey LP, John M, Anderson JA, Zvarich MT, Wise RA. Ascertainment of cause-specific mortality in COPD: operations of the TORCH Clinical Endpoint Committee. Thorax 2007;62:411-5

SCO30003. A multicentre, randomised, double-blind, parallel group, placebo-controlled study to investigate the long-term effects of salmeterol/fluticasone propionate (SERETIDE ${ }^{\circledR}$ / VIANI $^{\circledR} /$ ADVAIR $^{\circledR}$ ) $50 / 500 \mathrm{mcg}$ bd, salmeterol $50 \mathrm{mcg}$ bd and fluticasone propionate $500 \mathrm{mcg}$ bd, all delivered via the DISKUS $^{\circledR} /$ ACCUHALER $^{\circledR}$ inhaler, on the survival of subjects with chronic obstructive pulmonary disease (COPD) over 3 years of treatment. www.ctr.gsk.co.uk 2006.

Vestbo J, AJA, CPMA, CB, FGT, JC, et al. Bias due to withdrawal in long-term randomised trials in COPD: Evidence from the TORCH study. Clinical Respiratory Journal 2011; Vol. 5, issue 1:44-9.

Vestbo J, Calverley P, Celli B, Ferguson G, Jenkins C, Jones P, et al. The TORCH (TOwards a Revolution in COPD Health) survival study protocol. European Respiratory Journal 2004;24(2):206-10.
Wise RA, McGarvey LP, John M, Anderson JA, Zvarich MT. Reliability of cause-specific mortality adjudication in a COPD clinical trial. http://www.abstracts2view.com 2007:A120.

TRISTAN 2003 \{published and unpublished data\}

* Calverley P, Pauwels R, Vestbo J, Jones P, Pride N, Gulsvik A, et al. Combined salmeterol and fluticasone in the treatment of chronic obstructive pulmonary disease: a randomised controlled trial. Lancet 2003;361(9356):449-56.

Calverley PMA, Pauwels RA, Vestbo J, Jones PW, Pride NB, Gulsvik A, et al. Clinical improvements with salmeterol / fluticasone propionate combination in differing severities of COPD. http://www.abstracts2view.com 2003:A035 [Poster D50].

Calverley PMA, Pauwels RA, Vestbo J, Jones PW, Pride NB, Gulsvik A, et al. Salmeterol/fluticasone propionate combination for one year provides greater clinical benefit than its individual components. Proceedings of the 98th International American Thoracic Society Conference http://www.abstracts-on-line.com/ abstracts/ATS. 2002:A98 [Poster 306].

Calverly PMA, Pauwels R, Vestbo J, Jones P, Pride N, Gulsvik A, et al. Safety of salmeterol/fluticasone propionate combination in the treatment of chronic obstructive pulmonary disease. European Respiratory Journal 2002;20 Suppl 38:242 [P1572].

Hunjan MK, Chandler F. Numbers needed to treat (NNT) to avoid an exacerbation in patients with chronic obstructive pulmonary disease (COPD) using salmeterol/fluticasone propionate combination (SFC) and associated costs [Abstract]. American Thoracic Society 100th International Conference, May 21-26. 2004:D22 [Poster 503].

Hunjan MK, Williams DT. Costs of avoiding exacerbations in patients with chronic obstructive pulmonary disease (COPD) treated with salmeterol/ fluticasone propionate combination (Seretide) and salmeterol. European Respiratory Journal 2004;24 Suppl 48:291.

Hunjan MK, Williams DT. Salmeterol/ fluticasone propionate combination is clinically effective in avoiding exacerbations in patients with moderate/severe COPD. European Respiratory Journal 2004;24 Suppl 48:513s.

Jones PW, Edin HM, Anderson J. Salmeterol/fluticasone propionate combination improves health status in COPD patients. Proceedings of the 98th International American Thoracic Society Conference http://www.abstracts-on-line.com/ abstracts/ATS. 2002:A39 [Poster K39].

Jones PW, Ståhl E. Budesonide /formoterol sustains clinically relevant improvements in health status in COPD [Abstract]. European Respiratory Journal 2005;26 Suppl 49:Abstract 1352.

Jones PW, Vestbo J, Pauwels RA, Calverley PMA, Anderson JA, Spencer MD. Informative drop out in COPD studies. Investigation of health status of withdrawals in the TRISTAN study. 13th ERS Annual Congress, 27 Spetember 2003, Vienna. 2003:P1593.

Nitschmann S. Inhalational combination therapy in chronic obstructive lung disease. Tristan study. German Internist 2004;45(6):727-8. 
Pauwels R, Vestbo J, Calverley PMA, Jones PW, Pride NB, Gulsvik A. Characterization of exacerbations in the TRISTAN study of salmeterol / fluticasone propionate (SFC) combination in moderate to severe COPD. http://www.abstracts2view.com 2003.

Pauwels RA, Calverly PMA, Vestbo J, Jones PW, Pride N, Gulsvik A, et al. Reduction of exacerbations with salmeterol/ fluticasone combination $50 / 500 \mathrm{mcg}$ bd in the treatment of chronic obstructive pulmonary disease. European Respiratory Journal 2002;20 Suppl 38:240 [P1569].

SFCB3024. A multicentre, randomised, double-blind, parallel group, placebo-controlled study to compare the efficacy and safety of the salmeterol/FP combination product at a strength of $50 / 500 \mathrm{mcg}$ bd with salmeterol $50 \mathrm{mcg}$ bd alone and FP $500 \mathrm{mcg}$ bd alone, delivered via the DISKUS ${ }^{\mathrm{TM}} /$ ACCUHALER $^{\mathrm{TM}}$, in the treatment of subjects with chronic obstructive pulmonary disease (COPD) for 12 months. GlaxoSmithKline Clinical Trials Register (http:ctr.gsk.co.uk) 2005.

Spencer M, Briggs AH, Grossman RF, Rance L. Development of an economic model to assess the cost effectiveness of treatment interventions for chronic obstructive pulmonary disease. Pharmacoeconomics 2005;23(6):619-37.

Spencer MD, Karia N, Anderson J. The clinical significance of treatment benefits with the salmeterol/fluticasone propionate $50 / 500 \mathrm{mcg}$ combination in COPD. European Respiratory Journal 2004;24 Suppl 48:290.

Vestbo J, Calverley PMA, Pauwels R, Jones P, Pride N, Gulsvik A, et al. Absence of gender susceptibility to the combination of salmeterol and fluticasone in the treatment of chronic obstructive pulmonary disease. European Respiratory Journal 2002;20 Suppl 38:240 [P1570].

Vestbo J, Pauwels R, Anderson JA, Jones P, Calverley P. Early onset of effect of salmeterol and fluticasone propionate in chronic obstructive pulmonary disease. Thorax 2005;60(4):301-4.

Vestbo J, Pauwels RS, Calverley PMA, Jones PW, Pride NB, Gulsvik A. Salmeterol / fluticasone propionate combination produces improvement in lung function detectable within 24 Hours in moderate to severe COPD. http:// www.abstracts2view.com 2003.

Vestbo J, Soriano JB, Anderson JA, Calverley P, Pauwels R, Jones $\mathrm{P}$. Gender does not influence the response to the combination of salmeterol and fluticasone propionate in COPD. Respiratory Medicine 2004;98(11):1045-50.

\section{References to studies excluded from this review}

\section{Barnes 2005 \{published data only\}}

Barnes NC, Qui Y, Pavord I, Parker D, Johnson M, Jeffery PK. Salmeterol/fluticasone propionate (SFC) anti-inflammatory effects in COPD. American Thoracic Society International Conference. 2005:B93 [Poster 320].

\section{Cazzola 2003 \{published data only\}}

Cazzola M, Salzillo A, De Giglio C, Noschee P, D'Amato G. Formoterol/budesonide (FBC) in the treatment of acute exacerbations of COPD. European Respiratory Journal 2003;22 Suppl 45:P1859.

Cazzola M, Salzillo A, Noschese P, De Giglio C, Amato GD. Efficacy of a combination therapy with single inhaler budesonide/formoterol in the treatment of acute exacerbations of COPD. European Respiratory Journal 2004;24 Suppl 48:252.

Della Cioppa 2001 \{published data only\}

Della Cioppa G, Byrne A, Till D, Wood R. Formoterol demonstrates bronchodilator efficacy in patients with reversible or poorly reversible chronic obstructive pulmonary disease. European Respiratory Journal 2001;18 Suppl 33:177.

Greefhorst APM, Thomson MH, Byrne A, Till D. The efficacy of formoterol in patients with chronic obstructive pulmonary disease (COPD) is not influenced by concomitant corticosteroid use. European Respiratory Journal 2001;18 Suppl 33:515.

Kristufek P, Levine B, Della Cioppa G, Byrne A, Till D. Bronchodilatory effects of formoterol in patients with chronic obstructive pulmonary disease (COPD) are not influenced by concomitant corticosteroid use. European Respiratory Journal 2001;18 Suppl 33:514.

\section{Gosman 2006 \{published data only\}}

Gosman MME, Lapperre TS, Snoeck-Stroband JB, Jansen DF, Kerstjens HAM, Hiemstra PS, et al. Effect of 6 months therapy with inhaled fluticasone propionate (FP) with or without salmeterol (S) on bronchial inflammation in COPD. Proceedings of the American Thoracic Society 2006;A111:Poster J15.

\section{Jiang 2009 \{published data only\}}

Jiang Y, XW, WH, ZH, ZY, XX. Effects of salmeterol/fluticasone propionate on inflammation and innate immunity in COPD [Abstract]. Respirology 2009; Vol. 14 Suppl 3:A159 [OS 25-03].

\section{Lyseng-Williamson 2002 \{published data only\}}

Lyseng-Williamson KA, Keating GM. Inhaled salmeterol/ fluticasone propionate combination in chronic obstructive pulmonary disease. American Journal of Respiratory Medicine 2002;1(4):273-82.

\section{Mittmann 2010 \{published data only\}}

Mittmann N, HP, MC, BL, WT. Cost-effectiveness of budesonide/ formoterol added to tiotropium in COPD patients in Canada, Australia and Sweden [Abstract]. European Respiratory Society Annual Congress, Barcelona, Spain, September 18-22 2010: [5183].

\section{Nungtjik 2009 \{published data only\}}

Nungtjik AK, MH, YF, AB. Efficacy of combination of fluticasone propionate/salmeterol in a single inhaler (Diskus) on chronic obstructive pulmonary disease [Abstract]. Respirology 2009; Vol. 14 Suppl 3:A268 [PO 033]. 
Reynolds 2004 \{published data only\}

Reynolds NA, Perry CM, Keating GM. Budesonide/ formoterol in chronic obstructive pulmonary disease. Drugs 2004;64(4):431-41.

\section{Tzani 2010 \{published data only\}}

Tzani P, CE, NG, CE, AM, CA, et al. Reduction in air trapping and dyspnea with an extrafine combination of beclomethasone and formoterol in COPD [Abstract]. European Respiratory Society Annual Congress, Barcelona, Spain, September 18-22 2010: [P1204].

\section{Worth 2009 \{published data only\}}

Worth H, FK, PS, NU, MH. Budesonide/formoterol improves exercise tolerance compared with placebo and formoterol in COPD patients [Abstract]. European Respiratory Society Annual Congress, Vienna, Austria, September 12-16 2009:[201].

\section{Additional references}

\section{Agarwal 2010}

Agarwal R, Aggarwal AN, Gupta D, Jindal SK. Inhaled corticosteroids vs placebo for preventing COPD exacerbations. Chest 2010;137(2):318-25.

\section{Appleton 2006}

Appleton S, Poole P, Smith B, Veale A, Lasserson TJ, Chan MMK, Cates CJ. Long-acting beta2-agonists for poorly reversible chronic obstructive pulmonary disease. Cochrane Database of Systematic Reviews 2006, Issue 3. [DOI: 10.1002/14651858.CD001104.pub2]

\section{ATS}

Standards for the diagnosis and care of patients with chronic obstructive pulmonary disease. American Thoracic Society. American Journal of Respiratory and Critical Care Medicine. 1995/11/01 1995; Vol. 152, issue 5 Pt 2:S77-121. [1073-449X: (Print)]

\section{Boyd 1997}

Boyd G, Morice A, Pounsford J, Sibert M, Peslis N, Crawford C. An evaluation of salmeterol in the treatment of chronic obstructive pulmonary disease (COPD). European Respiratory Journal 1997; 10:815-21.

\section{Burge 2000}

Burge PS, Calverley PM, Jones PW, Spencer S, Anderson JA, Maslen TK. Randomised, double blind, placebo controlled study of fluticasone propionate in patients with moderate to severe chronic obstructive pulmonary disease: the ISOLDE trial. BMJ 2000;320:1297-303.

\section{Calverley 2003 a}

Calverley PMA, Pauwels R, Vestbo J, Jones P, Pride N, Gulsvik A, et al. Combined salmeterol and fluticasone in the treatment of chronic obstructive pulmonary disease: a randomised controlled trial. Lancet 2003;361:449-56.

\section{Calverley 2007}

Calverley PM, Anderson JA, Bartolome C, Ferguson GT, Jenkins C, Jones PW, et al. Salmeterol and fluticasone propionate and survival in chronic obstructive pulmonary disease. New England Journal of Medicine 2007;356(8):775-89.

\section{ERS}

Quanjer PH, Tammeling GJ, Cotes JE, Pedersen OF, Peslin R, Yernault JC. Lung volumes and forced ventilatory flows. Report Working Party Standardization of Lung Function Tests, European Community for Steel and Coal. Official Statement of the European Respiratory Society. European Respiratory Journal. 1993/03/01 1993; Vol. 16 Suppl:5-40. [0904-1850: (Print)]

\section{GOLD 2010}

Global Strategy for the Diagnosis, Management, and Prevention of COPD, Global Initiative for Chronic Obstructive Lung Disease (GOLD). Available from http://www.goldcopd.com 2010.

\section{Higgins 2008}

Higgins JPT, Green S, editors. Cochrane Handbook for Systematic Reviews of Interventions Version 5.0.1 [updated September 2008]. The Cochrane Collaboration, Available from www.cochrane-handbook.org, 2008.

\section{Jones 1997}

Jones PW, Bosh TK. Quality of life changes in COPD patients treated with salmeterol. American Journal of Respiratory and Critical Care Medicine 1997;155:1283-9.

\section{Keene 2008}

Keene ON, CPM, JPW, VJ, AJA. Statistical analysis of exacerbation rates in COPD: TRISTAN and ISOLDE revisited. European Respiratory Journal 2008;32(1):17-24. [1399-3003: (Electronic)]

\section{Lung Health 2000}

The Lung Health Study Research Group. Effect of inhaled triamcinolone on the decline in pulmonary function in chronic obstructive pulmonary disease. New England Journal of Medicine 2000;343:1902-9.

\section{Nannini 2007}

Nannini LJ, Cates CJ, Lasserson TJ, Poole P. Combined corticosteroid and long-acting beta-agonist in one inhaler versus inhaled steroids for chronic obstructive pulmonary disease. Cochrane Database of Systematic Reviews 2007, Issue 4. [DOI: 10.1002/14651858.CD006826]

\section{Nannini 2007a}

Nannini L, Cates CJ, Lasserson TJ, Poole P. Combined corticosteroid and long-acting beta-agonist in one inhaler versus placebo for chronic obstructive pulmonary disease. Cochrane Database of Systematic Reviews 2007, Issue 4. [DOI: 10.1002/14651858.CD003794.pub3]

\section{Nannini 2007b}

Nannini Luis J, Cates Christopher J, Lasserson Toby J, Poole P. Combined corticosteroid and long-acting beta-agonist in one inhaler versus long-acting beta-agonists for chronic obstructive 
pulmonary disease. Cochrane Database of Systematic Reviews 2007, Issue 4. [DOI: 10.1002/14651858.CD006829]

\section{NICE 2010}

National Clinical Guideline Centre. Chronic obstructive pulmonary disease: Management of chronic obstructive pulmonary disease in adults in primary and secondary care. Chronic obstructive pulmonary disease: management of chronic obstructive pulmonary disease in adults in primary and secondary care. London: National Clinical Guideline Centre, 2010. [URL: http://guidance.nice.org.uk/CG101/Guidance/pdf/ English]

\section{Pauwels 1999}

Pauwels RA, Lofdahl CG, Laitinen LA, Schouten JP, Postma DS, Pride NB, et al. Long-term treatment with inhaled budesonide in persons with mild chronic obstructive pulmonary disease who continue smoking. European Respiratory Society Study on Chronic Obstructive Pulmonary Disease. New England Journal of Medicine 1999;340(25):1948-53.

\section{RevMan 5 [Computer program]}

Copenhagen, The Nordic Cochrane Centre: The Cochrane Collaboration. Review Manager (RevMan) Version 5.1. Copenhagen, The Nordic Cochrane Centre: The Cochrane Collaboration, 2008.

\section{Rodrigo 2008}

Rodrigo GJ, Nannini LJ, Rodríguez-Roisin R. Safety of longacting $\beta$-agonists in stable COPD*. Chest 2008;133(5):1079-87.

\section{Rodrigo 2009}

Rodrigo GJ, Castro-Rodriguez JA, Plaza V. Safety and Efficacy of Combined Long-Acting $\beta$-Agonists and Inhaled Corticosteroids vs Long-Acting $\beta$-Agonists Monotherapy for Stable COPD. Chest 2009;136(4):1029-38.

\section{Singh 2010}

Singh S, LYK. An overview of the benefits and drawbacks of inhaled corticosteroids in chronic obstructive pulmonary disease. International Journal of Chronic Obstructive Pulmonary Disease. 2010/08/18 2010; Vol. 5:189-95. [1178-2005: (Electronic)]

\section{Spencer 2001}

Spencer S, Calverley PMA, Burge PS, Jones PW. Health status deterioration in patients with COPD. American Journal of Respiratory and Critical Care Medicine 2001;163:122-8.

\section{Spencer 2003}

Spencer S, Jones PW. Time course of recovery of health status following an infective exacerbation of chronic bronchitis. Thorax 2003;58:589-93.

\section{Vestbo 1999}

Vestbo J, Sorensen T, Lange P, Brix A, Torre P, Viskum K. Longterm effect of inhaled budesonide in mild and moderate chronic obstructive pulmonary disease: a randomised controlled trial. The Lancet 1999;353:1819-23.

\section{Yang 2007}

Yang IA, Fong K, Sim EHA, Black PN, Lasserson TJ. Inhaled corticosteroids for stable chronic obstructive pulmonary disease. Cochrane Database of Systematic Reviews 2007, Issue 2. [DOI: 10.1002/14651858.CD002991.pub2]

* Indicates the major publication for the study

\section{CHARACTERISTICS OF STUDIES}

\section{Characteristics of included studies [ordered by study ID]}

Calverley 2003

Methods Design: a multi-centre, randomised, double-blind, parallel-group, placebo-controlled study. Trial duration was 2 week run-in period followed by 52 weeks treatment. The trial included 109 centres in 15 countries

Participants: 512 patients were randomised (budesonide 257; formoterol 255)

Baseline characteristics: mean age 64 years; $74 \%$ male; mean $\mathrm{FEV}_{1} 1.0 \mathrm{~L}$; mean $\mathrm{FEV}_{1}$ predicted $36 \%$; mean SGRQ 48

Inclusion criteria: GOLD defined COPD (stages III and IV); $\geq 40$ years; COPD symptoms $>2$ years; smoking history $\geq 10$ pack years; $\mathrm{FEV}_{1} / \mathrm{FVC} \leq 70 \%$ pre-bronchodilator; $\mathrm{FEV}_{1} \leq 50 \%$ predicted; use of short acting beta ${ }_{2}$-agonists as reliever medication; $\geq 1$ COPD exacerbation requiring oral corticosteroids/antibiotics 2 to 12 months before first clinic visit

Exclusion criteria: history of asthma/rhinitis before 40 years of age; any relevant cardiovascular disorders; exacerbation of COPD requiring medical intervention within 4 weeks of run-in/during run-in phase; non-allowed medications: oxygen therapy; ICS (aside from study medication), disodium cromoglycate, leukotriene-antagonists, 5-lipoxygenase inhibitors, bronchodilators (other than study medication and terbutaline $0.5 \mathrm{mg}$ as needed), antihistamines, medication containing ephedrine, $\beta$-blocking agents daily (2 weeks) 
1. budesonide $800 \mu \mathrm{g}$ per day: 2 x $200 \mu \mathrm{g}$ twice daily

2. formoterol $18 \mu \mathrm{g}$ per day: 2 x $4.5 \mu \mathrm{g}$ twice daily

Inhaler device: Turbuhaler

Co-treatment: terbutaline $0.5 \mathrm{mg}$ as needed, courses of oral corticosteroids (maximum 3 weeks per course) and antibiotics in the event of exacerbations, parenteral steroids and/or nebulised treatment (single injections/inhalations) at emergency visits

The following medications were disallowed from recruitment: inhaled steroids (except the study medication), disodium cromoglycate, leukotriene antagonists or 5-lipoxygenase (5-LO) inhibitors, bronchodilators (other than study medication and terbutaline $0.5 \mathrm{mg}$ as needed), antihistamines, any medication containing ephedrine, and $\beta$-blockers, including eye-drops.

The following medications were withheld prior to recruitment: short-acting inhaled or oral $\beta_{2}$-agonists ( $6 \mathrm{~h}$ before), inhaled or oral long-acting $\beta_{2}$-agonists ( $48 \mathrm{~h}$ ), inhaled short-acting anticholinergics ( $8 \mathrm{~h}$ ), inhaled long-acting anticholinergics (7 days), xanthine-containing derivatives ( $48 \mathrm{~h}$ ), xanthine-containing derivatives $(24 \mathrm{~h}$ ), leukotriene antagonists or 5-LO inhibitors (48 h)

Outcomes

Number of exacerbations; time to first exacerbation; time to and number of oral corticosteroid-treated episodes; change in post-dose $\mathrm{FEV}_{1}$; slow VC; morning and evening PEF; quality of life (SGRQ), symptoms, use of reliever medication, adverse events

Notes P values used to calculate pooled SEMs for the following outcomes: Health-related quality of life; FEV ; $_{1}$ rescue medication

Exacerbations defined as requiring medical intervention (oral antibiotics and/or corticosteroids or hospitalisation)

\begin{tabular}{|c|c|c|}
\hline \multicolumn{3}{|l|}{ Risk of bias } \\
\hline Bias & Authors' judgement & Support for judgement \\
\hline $\begin{array}{l}\text { Random sequence genera- } \\
\text { tion (selection bias) }\end{array}$ & Unclear risk & Not described \\
\hline $\begin{array}{l}\text { Allocation concealment } \\
\text { (selection bias) }\end{array}$ & Unclear risk & Not described \\
\hline $\begin{array}{l}\text { Blinding (performance } \\
\text { bias and detection bias) } \\
\text { All outcomes }\end{array}$ & Unclear risk & Not described \\
\hline $\begin{array}{l}\text { Incomplete outcome data } \\
\text { (attrition bias) } \\
\text { All outcomes }\end{array}$ & Low risk & $\begin{array}{l}\text { The withdrawal rates were } 40 \% \text { in the inhaled corticosteroid (budesonide) } \\
\text { group and } 44 \% \text { in the long-acting beta }{ }_{2} \text {-agonist (formoterol) group. However } \\
\text { an intention-to-treat analysis was used }\end{array}$ \\
\hline $\begin{array}{l}\text { Selective reporting (re- } \\
\text { porting bias) }\end{array}$ & Low risk & All collected data reported \\
\hline
\end{tabular}

Hanania 2003

\section{Methods}

Design: a multi-centre, randomised, double-blind, placebo-controlled, parallel-group study from November 1998 to August 2000. Trial duration was 2 week run-in period followed by 24 weeks treatment. The trial included 76 hospitals in the USA. Randomization was stratified by reversibility and investigative site 
Hanania 2003 (Continued)

Participants

Participants: 360 patients were randomised (salmeterol 177; fluticasone 183)

Baseline characteristics: mean age 64 years; $62 \%$ male; mean $\mathrm{FEV}_{1} 1.3 \mathrm{~L}$; mean $\mathrm{FEV}_{1}$ predicted $42 \%$; mean reversibility ( $\mathrm{FEV}_{1} \%$ predicted) was $8.8 \%$ increase in non-reversible patients

Inclusion criteria: stable COPD, $\mathrm{FEV}_{1} 40$ to $65 \%$ predicted, $\mathrm{FEV}_{1} / \mathrm{FVC}<70 \%$ predicted, symptoms of chronic bronchitis and moderate dyspnoea

Exclusion criteria: current diagnosis of asthma, use of oral steroids in past 6 weeks, abnormal ECG, long-term oxygen therapy, moderate - severe exacerbation in run-in, other significant medical disorder

Interventions

Run-in: 2 weeks treatment with placebo inhaler and short acting beta ${ }_{2}$-agonist as needed

1. salmeterol $100 \mu \mathrm{g}$ per day: $50 \mu \mathrm{g}$ twice daily

2. fluticasone propionate $500 \mu \mathrm{g}$ per day: $250 \mu \mathrm{g}$ twice daily

Inhaler device: Diskus

Co-treatment: Patients were given as-needed albuterol

\begin{tabular}{|c|c|}
\hline Outcomes & $\begin{array}{l}\text { Exacerbations; change in pre-dose and } 2 \mathrm{~h} \text { post-dose } \mathrm{FEV}_{1} \text { from baseline to end of study. PEF data not } \\
\text { stratified by reversibility; morning PEF; Quality of life: (CRDQ, CBSQ not stratified by reversibility); dys } \\
\text { noea (BDI, TDI); symptoms; use of reliever medication (salbutamol); adverse events }\end{array}$ \\
\hline \multirow[t]{3}{*}{ Notes } & $\begin{array}{l}\text { Reversibility was defined as } \mathrm{a} \geq 12 \% \text { and } 200 \mathrm{~mL} \text { increase in } \mathrm{FEV}_{1} \text { from baseline following the adminis- } \\
\text { tration of } 400 \mu \mathrm{g} \text { albuterol. }\end{array}$ \\
\hline & Change in $\mathrm{FEV}_{1}$ : mean group SE estimated from reversibility stratified SEs, then used to calculate SD \\
\hline & $\begin{array}{l}\text { Exacerbations were defined by treatment: moderate exacerbations requiring treatment with antibi- } \\
\text { otics and/or corticosteroids, and severe exacerbations requiring hospitalisation }\end{array}$ \\
\hline
\end{tabular}

Risk of bias

\begin{tabular}{|c|c|c|}
\hline Bias & Authors' judgement & Support for judgement \\
\hline $\begin{array}{l}\text { Random sequence genera- } \\
\text { tion (selection bias) }\end{array}$ & Unclear risk & Not described \\
\hline $\begin{array}{l}\text { Allocation concealment } \\
\text { (selection bias) }\end{array}$ & Unclear risk & Not described \\
\hline $\begin{array}{l}\text { Blinding (performance } \\
\text { bias and detection bias) } \\
\text { All outcomes }\end{array}$ & Unclear risk & Not described \\
\hline $\begin{array}{l}\text { Incomplete outcome data } \\
\text { (attrition bias) } \\
\text { All outcomes }\end{array}$ & Low risk & $\begin{array}{l}\text { In order to account for patient withdrawals, endpoint was used as the primary } \\
\text { time point and was defined as the last on-treatment post-baseline assessment } \\
\text { excluding any data from the discontinuation visit. }\end{array}$ \\
\hline $\begin{array}{l}\text { Selective reporting (re- } \\
\text { porting bias) }\end{array}$ & Low risk & All collected data reported \\
\hline
\end{tabular}

Inhaled corticosteroids versus long-acting beta ${ }_{2}$-agonists for chronic obstructive pulmonary disease (Review) 
Mahler 2002

\begin{tabular}{|c|c|}
\hline Methods & $\begin{array}{l}\text { Design: a randomised, double-blind, placebo-controlled, parallel-group study. Trial duration was } 2 \\
\text { week run-in period followed by } 24 \text { weeks treatment. The trial included } 65 \text { centres in the USA. Randomi- } \\
\text { sation was stratified by reversibility and investigative site }\end{array}$ \\
\hline \multirow[t]{6}{*}{ Participants } & Participants: 328 patients were randomised (salmeterol 160; fluticasone 168) \\
\hline & Baseline characteristics: mean age 63 years; $63 \%$ male; mean predose $\mathrm{FEV}_{1} 1.2 \mathrm{~L}$; mean FEV 1 predict- \\
\hline & ed $40 \%$ \\
\hline & $\mathrm{FEV}_{1}<65 \%$ predicted and $>0.70 \mathrm{~L}$. Baseline pre-bronchodilation $\mathrm{FEV}_{1} / \mathrm{FVC} \leq 70 \%$ predicted. Age $>40$ \\
\hline & $\begin{array}{l}20 \text { pack-year history smoking, day or night symptoms present on } 4 \text { out of last } 7 \text { days during run-in peri- } \\
\text { od }\end{array}$ \\
\hline & $\begin{array}{l}\text { Exclusion criteria: history of asthma, corticosteroid use in last } 6 \text { weeks, abnormal ECG, oxygen thera- } \\
\text { py, moderate or severe exacerbation during run-in, significant concurrent disease }\end{array}$ \\
\hline
\end{tabular}

Interventions

Run-in: 2 weeks treatment with placebo inhaler and SABA as needed

1. salmeterol $100 \mu \mathrm{g}$ per day: $50 \mu \mathrm{g}$ twice daily

2. fluticasone propionate $1000 \mu \mathrm{g}$ per day: $500 \mu \mathrm{g}$ twice daily

Inhaler device: Diskus

Co-treatment: Patients were given as-needed albuterol

\section{Outcomes}

Exacerbations, change in $\mathrm{FEV}_{1}$ from baseline to end of study; morning PEF; quality of life (CRDQ, CBSQ not stratified by reversibility); dyspnoea (BDI, TDI); symptoms; use of reliever medication (salbutamol); adverse events

\begin{tabular}{ll}
\hline Notes & Reversibility defined as an increase of $12 \%$ and $200 \mathrm{~mL}$ in $\mathrm{FEV}_{1}$ following albuterol $400 \mu \mathrm{g}$ \\
& Change in $\mathrm{FEV}_{1}$ : mean group SE estimated from reversibility stratified SEs, then used to calculate SD
\end{tabular}

\section{Risk of bias}

\begin{tabular}{lll}
\hline Bias & Authors' judgement & Support for judgement \\
\hline $\begin{array}{l}\text { Random sequence genera- } \\
\text { tion (selection bias) }\end{array}$ & Unclear risk & Not described \\
\hline $\begin{array}{l}\text { Allocation concealment } \\
\text { (selection bias) }\end{array}$ & Unclear risk & Not described \\
\hline $\begin{array}{l}\text { Blinding (performance } \\
\text { bias and detection bias) } \\
\text { All outcomes }\end{array}$ & Unclear risk & Not described \\
\hline
\end{tabular}

Incomplete outcome data Low risk (attrition bias)

All outcomes
Endpoint analysis for both predose and post-dose $\mathrm{FEV}_{1}$ was performed to ensure that the patients prematurely withdrawing from the trial did not impact the robustness of the $\mathrm{FEV}_{1}$ results. The endpoint was defined as the last ontreatment post-baseline assessment excluding any data from the discontinuation visit. The appropriateness of this analysis was supported by evaluating the data using alternative methods of handling dropouts, including multiple imputation, analysis of only completers, and recursive regression imputation

Selective reporting (re- Low risk $\quad$ All collected data reported
porting bias)




\section{Szafranski 2003}

Design: a multi-centre, randomised, double-blind, placebo-controlled, parallel-group study. Trial du-
ration was 2 week run-in period and 52 weeks treatment. The trial included 89 centres in 11 countries
from Central \& South America, Europe and South Africa

Participants

Participants: 399 patients were randomised (formoterol 201; budesonide 198).

Baseline characteristics: mean age 64 years; $78 \%$ male; mean predose $\mathrm{FEV}_{1} 1.0 \mathrm{~L}$; mean $\mathrm{FEV}_{1}$ predicted $36 \%$, mean reversibility $6 \%$ predicted normal

Inclusion criteria: age $\geq 40$ years; COPD for $\geq 2$ years; smoking history $\geq 10$ pack years; $\mathrm{FEV}_{1} \leq 50 \%$ predicted; $\mathrm{FEV}_{1} / \mathrm{FVC} \leq 70 \%$; Symptom score $\geq 2$ during at least 7 days of run-in; use of bronchodilators for reliever medication; $\geq 1$ severe COPD exacerbation within 2-12 months before study entry

Exclusion criteria: history of asthma/rhinitis before age of 40; using beta-blockers; current respiratory tract disease other than COPD

Run-in: 2 weeks. Treatment as-needed with short-acting bronchodilators only
Interventions $\quad$ budesonide $800 \mu \mathrm{g}$ per day: $2 \times 200 \mu \mathrm{g}$ twice daily
2. formoterol $18 \mu \mathrm{g}$ per day: $2 \times 4.5 \mu \mathrm{g}$ twice daily
Inhaler device: Turbuhaler
Co-treatment: Only study medication was allowed during the treatment period and terbutaline 0.5 m
when
needed as reliever medication
Number of mild and severe exacerbations; change in post-dose FEV 1 as \% from baseline; dyspnoea
(MMRC); symptoms; morning and evening PEF; quality of life (SGRQ); use of reliever medication; ad-
verse events
Cutcomes
Classified as 'poorly reversible' subgroup
Severe exacerbation defined as requirement of oral steroids and/or antibiotics and/or hospitalisation
for respiratory symptoms. Mild exacerbation defined as requirement of $\geq 4$ inhalations per day
P values used to calculate pooled SEMs for following outcomes: Symptoms; rescue medication usage

\section{Risk of bias}

\begin{tabular}{|c|c|c|}
\hline Bias & Authors' judgement & Support for judgement \\
\hline $\begin{array}{l}\text { Random sequence genera- } \\
\text { tion (selection bias) }\end{array}$ & Low risk & $\begin{array}{l}\text { Computer-generated scheme at AstraZeneca, Lund, Sweden. At each centre, } \\
\text { eligible patients received an enrolment code and then after run-in, partici- } \\
\text { pants were allocated the next consecutive patient number }\end{array}$ \\
\hline $\begin{array}{l}\text { Allocation concealment } \\
\text { (selection bias) }\end{array}$ & Unclear risk & Not described \\
\hline $\begin{array}{l}\text { Blinding (performance } \\
\text { bias and detection bias) } \\
\text { All outcomes }\end{array}$ & Low risk & $\begin{array}{l}\text { All the Turbuhaler inhalers were identical to ensure that the patient, pharma- } \\
\text { cist and the investigator were blinded to the allocated treatment }\end{array}$ \\
\hline $\begin{array}{l}\text { Incomplete outcome data } \\
\text { (attrition bias) } \\
\text { All outcomes }\end{array}$ & Low risk & $\begin{array}{l}\text { The withdrawal rates were relatively large but even between the inhaled cor- } \\
\text { ticosteroid (budesonide) group ( } 31 \% \text { ) and the long-acting beta } 2 \text {-agonist (for- } \\
\text { moterol) group (32\%). An intention-to-treat analysis was used }\end{array}$ \\
\hline $\begin{array}{l}\text { Selective reporting (re- } \\
\text { porting bias) }\end{array}$ & Low risk & All collected data reported \\
\hline
\end{tabular}


Tashkin 2008

Methods

Design: a multi-centre, randomised, double-blind, double-dummy, placebo-controlled, parallel-group study. Trial duration was 2 week run-in, 6 months treatment, and telephone follow-up 4 weeks after the last study visit. The trial included 194 centres in 5 countries ( $42 \%$ US)

Participants

Participants: 559 patients were randomised (budesonide 275; formoterol 284)

Baseline characteristics: mean age 63 years; $67 \%$ male; mean predose $\mathrm{FEV}_{1} 1.03 \mathrm{~L}$; mean predose

$\mathrm{FEV}_{1}$ predicted $40 \%$

Inclusion criteria: Current or ex-smokers aged $\geq 40$ years; clinical diagnosis of COPD with symptoms for $>2$ years; $\geq 1$ COPD exacerbation requiring oral corticosteroids/antibiotics 1 to 12 months before first clinic visit; use of SABAs as reliever medication; predose $\mathrm{FEV}_{1} \leq 50 \%$ predicted; predose $\mathrm{FEV}_{1} / \mathrm{FVC}$ $\leq 70 \%$; smoking history $\geq 10$ pack years; dyspnoea scale (MMRC) $\geq 2$; breathlessness, cough and sputum scale (BCSS) score $\geq 2$ per day for at least half of the 2-week run-in period

Exclusion criteria: history of asthma/rhinitis before 40 years of age; significant/unstable cardiovascular disorder; clinically significant respiratory tract disorder other than COPD; homozygous $\alpha-1$ antitrypsin deficiency; if the patient needed additions or alterations to their usual COPD maintenance therapy or an increment in rescue therapy due to worsening symptoms within 30 days before screening or during the run-in; oral or ophthalmic non-cardioselective beta-adrenoceptor antagonists, oral corticosteroids, pregnancy and breast-feeding

Interventions

Run-in: 2 weeks. Patients continued ICS mono-therapy if they had previously been receiving ICS alone or in combination with a LABA, and patients who had previously been receiving anticholinergic therapies were placed on stable doses of ipratropium bromide. A short-acting beta ${ }_{2}$-adrenoceptor agonist was allowed for rescue use

1. budesonide $640 \mu \mathrm{g}$ per day: 2 x $160 \mu \mathrm{g}$ twice daily (Turbuhaler)

2. formoterol $18 \mu$ g per day: 2 × $4.5 \mu$ g twice daily (pMDI)

\section{Co-treatment:}

Allowed: Ephedrine-free (or other bronchodilator-free) antitussives and mucolytics, nasal corticosteroids, stable-dose non-nebulized ipratropium bromide, oral or ophthalmic cardioselective beta-adrenoceptor antagonists, study-provided salbutamol (albuterol) as rescue medication, medications allowed for exacerbations after randomisation: oral and parenteral corticosteroids (not depot formulations), acute use of xanthines, increased use of inhaled beta-adrenoceptor agonists and ipratropium bromide, and nebulized beta-adrenoceptor agonists and ipratropium bromide

Disallowed: Long-acting anticholinergics, inhaled LABAs (other than study medication), inhaled SABAs (other than salbutamol [albuterol] for rescue), oral beta-adrenoceptor agonists, ephedrine-containing medication, leukotriene receptor antagonists and 5-lipoxygenase inhibitors, xanthine-containing derivatives (except in short-term treatment of exacerbations), disodium cromoglygates, non-cardioselective beta-adrenoceptor antagonists, ICSs (other than study medication)

Outcomes Pre- and post-dose $\mathrm{FEV}_{1}$; inspiratory capacity; FVC; morning and evening PEF; dyspnoea (BCSS); quality of life (SGRQ); exacerbations; use of reliever medication (beta-agonist); symptoms; adverse events

Notes Exacerbations were defined as respiratory symptoms requiring treatment with a course of oral steroids and/or hospitalisation

\section{Risk of bias}

\begin{tabular}{lll}
\hline Bias & Authors' judgement & Support for judgement \\
\hline $\begin{array}{l}\text { Random sequence genera- } \\
\text { tion (selection bias) }\end{array}$ & Low risk & $\begin{array}{l}\text { Eligible patients were randomised in balanced blocks according to a comput- } \\
\text { er-generated randomisation scheme at each site }\end{array}$ \\
\hline
\end{tabular}


Tashkin 2008 (Continued)

\begin{tabular}{l}
$\begin{array}{l}\text { Allocation concealment } \\
\text { (selection bias) }\end{array}$ \\
\hline
\end{tabular}

\begin{tabular}{|c|c|c|}
\hline $\begin{array}{l}\text { Blinding (performance } \\
\text { bias and detection bias) } \\
\text { All outcomes }\end{array}$ & Low risk & $\begin{array}{l}\text { To maintain blinding, patients received both a pressurized metered-dose in- } \\
\text { haler ( } \mathrm{pMDI} \text { ) and a dry powder inhaler (DPI) containing either active treatment } \\
\text { or placebo, or combinations of active treatment and placebo, as appropriate }\end{array}$ \\
\hline $\begin{array}{l}\text { Incomplete outcome data } \\
\text { (attrition bias) }\end{array}$ & Low risk & $\begin{array}{l}\text { The withdrawal rates were } 23 \% \text { in the inhaled corticosteroid (budesonide) } \\
\text { group and } 22 \% \text { in the long- acting beta } 2 \text {-agonist (formoterol) group. Howev- }\end{array}$ \\
\hline All outcomes & & $\begin{array}{l}\text { er the efficacy analysis set (i.e. intention-to-treat population) included all ran- } \\
\text { domised patients who received at least one dose of study medication and con- } \\
\text { tributed sufficient data for at least one co-primary or secondary efficacy end- } \\
\text { point during the randomised treatment period }\end{array}$ \\
\hline
\end{tabular}

Selective reporting (re- Low risk $\quad$ All collected data reported
porting bias)

\section{TORCH 2007}

Design: a multi-centre, randomised, double-blind, placebo-controlled, parallel-group study.
Trial duration was 2 week run-in period and 156 weeks treatment. The trial included 444 centres in 42
countries in North America, Central America and Asia Pacific

\begin{tabular}{|c|c|}
\hline \multirow[t]{4}{*}{ Participants } & $\begin{array}{l}\text { Participants: } 3093 \text { patients were randomised (salmeterol: } 1542 ; \text { fluticasone } 1551 \text { ) } \\
\text { Baseline characteristics: mean age } 65 \text { years; } 76 \% \text { male; mean } \mathrm{FEV}_{1} \text { predicted } 44 \% \text {, mean predose }\end{array}$ \\
\hline & $\mathrm{FEV}_{1} 1.1 \mathrm{~L}$, mean SGRQ score 50 \\
\hline & $\begin{array}{l}\text { Inclusion criteria: male/female } 40-80 \text { years of age; diagnosis of COPD (ERS); }<10 \% \text { reversibility of pre- } \\
\text { dicted } \mathrm{FEV}_{1} ; \mathrm{FEV} 1 / \mathrm{FVC} \text { ratio }<70 \% ; \mathrm{FEV}_{1}<60 \% \text { predicted; } \geq 10 \text { pack year smoking history }\end{array}$ \\
\hline & $\begin{array}{l}\text { Exclusion criteria: Asthma or respiratory diseases other than COPD; lung volume reduction surgery/ } \\
\text { lung transplant; requirement for }>12 \mathrm{~h} / \mathrm{day} \text { long term oxygen therapy; long term oral corticosteroid } \\
\text { therapy; serious uncontrolled disease likely to interfere with medication/cause death in next three } \\
\text { years }\end{array}$ \\
\hline
\end{tabular}

Interventions $\quad$ Run-in: 2 weeks. All maintenance treatment with ICS and LABA ceased, but patients could continue other medications for COPD

1. salmeterol $100 \mu \mathrm{g}$ per day: $50 \mu \mathrm{g}$ twice daily

2. fluticasone $1000 \mu \mathrm{g}$ per day: $500 \mu \mathrm{g}$ twice daily

Inhaler device: DPI (Diskus)

Co-treatment: Patients could continue medications for COPD other than corticosteroids and inhaled long-acting bronchodilators

$\begin{array}{ll}\text { Outcomes } & \text { All cause mortality; frequency of exacerbations; health status (SGRQ); change in post-dose FEV } \text { from } \\ \text { baseline to end of study; adverse events }\end{array}$

\section{Notes}

Exacerbation defined as symptomatic deterioration requiring treatment with antibiotics, systematic corticosteroids, hospitalisation or a combination of these

\section{Risk of bias}

Bias Authors' judgement Support for judgement


TORCH 2007 (Continued)

Random sequence genera- Low risk tion (selection bias)
Eligible patients were randomly assigned to study treatment in accordance with the randomisation schedule, which was generated using the GW computer program Patient Allocation for Clinical Trials (PACT). Patients were randomised in permuted blocks with stratification according to country and smoking status.

Allocation concealment Low risk
(selection bias)

\begin{abstract}
Medication was allocated by the use of three numbers as follows.
- Each subject who was screened was allocated a subject number. This number was unique to each subject and was assigned from a list provided to the site, in chronological order.

- Each subject who satisfied the randomisation criteria was assigned a unique treatment number from the Interactive Voice Response (IVR) system which is part of the System for Central Allocation of Drug (SCAD). Once a treatment number had been assigned to a subject, it could not be assigned to any other subject. Neither the subject nor the investigator knew to which treatment arm a subject had been allocated.

- At each treatment visit the subject was provided with a treatment pack. Every pack number was unique and corresponded to the study medication pack which was dispensed to the subject at the visit
\end{abstract}

A specialist IVR system company, ClinPhone, managed this system. At the randomisation visit (Visit 2) the principal investigator or designee contacted the IVR system through an automated 24-hour telephone number; upon providing their unique personal identification number (PIN) and answering a series of questions, the site was provided with the subject's treatment number as well as a pack number
Neither the subject nor the investigator knew to which treatment arm a subject had been allocated. At each treatment visit each subject was issued with a treatment pack containing DISKUS/ACCUHALER inhalers. The inhalers contained either of the four treatments (salmeterol/fluticasone propionate combination product, fluticasone propionate, salmeterol, or placebo) in accordance with the randomisation schedule. The inhalers were labelled in accordance with all applicable regulatory requirements. Each treatment pack and study treatment inhaler was labelled with the protocol number, storage and dosing instructions by GW Research and Development

$\begin{array}{ll}\begin{array}{l}\text { Incomplete outcome data } \\ \text { (attrition bias) }\end{array} & \text { Low risk } \\ \text { All outcomes } & \begin{array}{l}\text { For patients who withdrew from the study prematurely, all data on exacerba- } \\ \text { tions, health status, and lung function available at the time of a patient's with- } \\ \text { drawal from the study were included in the analysis. All efficacy analyses were } \\ \text { performed according to the intention-to-treat principle }\end{array}\end{array}$

$\begin{array}{lll}\text { Selective reporting (re- } \quad \text { Low risk } & \text { All collected data reported } \\ \text { porting bias) }\end{array}$

porting bias)

\section{TRISTAN 2003}

$\begin{array}{ll}\text { Methods } & \text { Design: a multi-centre, randomised, double-blind, placebo-controlled, parallel-group study. Trial du- } \\ \text { ration was } 2 \text { week run-in period, } 52 \text { weeks treatment, and 2-week follow-up. The trial included } 196 \text { cen- } \\ \text { tres in } 25 \text { countries }\end{array}$

Participants

Participants: 746 patients were randomised (salmeterol: 372; fluticasone 374)

Baseline characteristics: mean age 63 years; $70 \%$ male; mean reversibility ( $\mathrm{FEV}_{1} \%$ predicted) $3.7 \%$; mean $\mathrm{FEV}_{1}$ predicted $45 \%$, mean predose $\mathrm{FEV}_{1} 1.25 \mathrm{~L}$, mean SGRQ score 49

Inclusion criteria: male/female; poor reversibility $<10 \%$ increase of predicted $\mathrm{FEV}_{1} 30$ minutes after inhaling $400 \mu \mathrm{g}$ salbutamol; $\mathrm{FEV}_{1} / \mathrm{FVC}$ ratio $<70 \%$; baseline $\mathrm{FEV}_{1} 25-75 \%$ predicted; $\geq 10$ pack year 
TRISTAN 2003 (Continued)

smoking history, chronic bronchitis; history of exacerbations (at least 1 in the last year) requiring oral corticosteroids and/or antibiotics. At least one episode of acute COPD per year in the previous 3 years Exclusion criteria: respiratory disorders other than COPD, oxygen treatment, systemic corticosteroids, high doses of inhaled corticosteroids ( $>1000 \mu \mathrm{g}$ daily beclomethasone dipropionate, budesonide or flunisolide or $>500 \mu \mathrm{g}$ daily fluticasone) or antibiotics in the four weeks before the 2 week runin period

Outcomes Change in pre- and post-dose $\mathrm{FEV}_{1}$ from baseline to end of study; use of reliever medication (salbutamol); symptom scores; exacerbation rate; quality of life (SGRQ); FVC; adverse events

\section{Notes}

Exacerbations were defined a priori as a worsening of COPD symptoms that required treatment with antibiotics, oral corticosteroids, or both

\section{Risk of bias}

Bias Authors' judgement Support for judgement

Random sequence genera- Low risk tion (selection bias)
A randomisation schedule generated by the patient allocation for clinical trials (PACT) program was used to assign patients to study treatment groups. Every participating centre was supplied with a list of patient numbers (assigned to patients at their first visit) and a list of treatment numbers. Patients who satisfied the eligibility criteria were assigned the next sequential treatment number from the list

\begin{tabular}{lll}
$\begin{array}{l}\text { Allocation concealment } \\
\text { (selection bias) }\end{array}$ & Unclear risk & Not described \\
\hline $\begin{array}{l}\text { Blinding (performance } \\
\text { bias and detection bias) }\end{array}$ & Low risk & $\begin{array}{l}\text { Study drugs were labelled in a way to ensure that both the patient and the in- } \\
\text { vestigator were unaware of the allocated treatment. Salmeterol and fluticas- } \\
\text { oll outcomes combination ( } 50 / 500 \mu g \text { twice daily), salmeterol (50 } \mu \text { twice daily), fluti- } \\
\text { casone }(500 \mu g \text { twice daily) and placebo were packaged in identical inhaler de- } \\
\text { vices }\end{array}$
\end{tabular}

\section{Incomplete outcome data Unclear risk} (attrition bias)

All outcomes
The withdrawal rates were even between the inhaled corticosteroid (budesonide) group (29\%) and the long-acting beta 2 -agonist (formoterol) group $(32 \%)$ and the $\%$ of patients lost to follow-up were only $2.1 \%$ and $2.2 \%$ for the two groups respectively. However, it was unclear if patients discontinuing the allocated study treatment were analysed according to an intention-to-treat principle

Selective reporting (re- Low risk $\quad$ All collected data reported
porting bias)


Characteristics of excluded studies [ordered by study ID]

\begin{tabular}{ll}
\hline Study & Reason for exclusion \\
\hline Barnes 2005 & No ICS and LABA monocomponents \\
\hline Cazzola 2003 & No ICS and LABA monocomponents \\
\hline Della Cioppa 2001 & No ICS and LABA monocomponents \\
\hline Gosman 2006 & No ICS and LABA monocomponents \\
\hline Jiang 2009 & No ICS and LABA monocomponents \\
\hline Lyseng-Williamson 2002 & Review article \\
\hline Mittmann 2010 & No ICS and LABA monocomponents \\
\hline Nungtjik 2009 & No ICS and LABA monocomponents \\
\hline Reynolds 2004 & Review article \\
\hline Tzani 2010 & No ICS and LABA monocomponents \\
\hline Worth 2009 & No ICS monocomponent \\
\hline
\end{tabular}

DATA AND ANALYSES

Comparison 1. Inhaled corticosteroids (ICS) versus long-acting beta ${ }_{2}$-agonists (LABA) by ICS and LABA

\begin{tabular}{|c|c|c|c|c|}
\hline Outcome or subgroup title & No. of studies & $\begin{array}{l}\text { No. of partici- } \\
\text { pants }\end{array}$ & Statistical method & Effect size \\
\hline 1 Exacerbation rate ratios & 4 & 4750 & Risk Ratio (Fixed, 95\% Cl) & $0.96[0.89,1.02]$ \\
\hline $\begin{array}{l}\text { 1.1 Fluticasone versus Salme- } \\
\text { terol }\end{array}$ & 2 & 3839 & Risk Ratio (Fixed, 95\% Cl) & $0.97[0.91,1.05]$ \\
\hline $\begin{array}{l}1.2 \text { Budesonide versus For- } \\
\text { moterol }\end{array}$ & 2 & 911 & Risk Ratio (Fixed, 95\% Cl) & $0.86[0.73,1.03]$ \\
\hline 2 Exacerbations & 2 & & Odds Ratio (M-H, Fixed, 95\% Cl) & Subtotals only \\
\hline $\begin{array}{l}\text { 2.1 Fluticasone versus Salme- } \\
\text { terol }\end{array}$ & 2 & 688 & Odds Ratio (M-H, Fixed, 95\% Cl) & $1.22[0.89,1.67]$ \\
\hline $\begin{array}{l}3 \text { Hospitalisations due to exac- } \\
\text { erbations }\end{array}$ & 1 & & Risk Ratio (Fixed, 95\% Cl) & Totals not selected \\
\hline $\begin{array}{l}\text { 3.1 Fluticasone versus Salme- } \\
\text { terol }\end{array}$ & 1 & & Risk Ratio (Fixed, 95\% Cl) & $0.0[0.0,0.0]$ \\
\hline
\end{tabular}




\begin{tabular}{|c|c|c|c|c|}
\hline Outcome or subgroup title & No. of studies & $\begin{array}{l}\text { No. of partici- } \\
\text { pants }\end{array}$ & Statistical method & Effect size \\
\hline 4 Pneumonia adverse event & 3 & 4164 & Odds Ratio (M-H, Fixed, 95\% Cl) & $1.38[1.10,1.73]$ \\
\hline $\begin{array}{l}\text { 4.1 Fluticasone versus Salme- } \\
\text { terol }\end{array}$ & 1 & 3093 & Odds Ratio (M-H, Fixed, 95\% Cl) & $1.43[1.13,1.81]$ \\
\hline $\begin{array}{l}\text { 4.2 Budesonide versus For- } \\
\text { moterol }\end{array}$ & 2 & 1071 & Odds Ratio (M-H, Fixed, 95\% Cl) & $0.84[0.36,1.96]$ \\
\hline $\begin{array}{l}5 \text { Pneumonia serious adverse } \\
\text { event }\end{array}$ & 5 & 5086 & $\begin{array}{l}\text { Peto Odds Ratio (Peto, Fixed, 95\% } \\
\mathrm{Cl} \text { ) }\end{array}$ & $1.48[1.13,1.94]$ \\
\hline $\begin{array}{l}5.1 \text { Fluticasone versus Salme- } \\
\text { terol }\end{array}$ & 4 & 4527 & $\begin{array}{l}\text { Peto Odds Ratio (Peto, Fixed, 95\% } \\
\mathrm{Cl} \text { ) }\end{array}$ & $1.46[1.12,1.92]$ \\
\hline $\begin{array}{l}5.2 \text { Budesonide versus For- } \\
\text { moterol }\end{array}$ & 1 & 559 & $\begin{array}{l}\text { Peto Odds Ratio (Peto, Fixed, 95\% } \\
\mathrm{Cl} \text { ) }\end{array}$ & $2.82[0.40,20.16]$ \\
\hline 6 Pre-dose FEV1 & 4 & 1993 & Mean Difference (Fixed, 95\% Cl) & $-18.99[-37.46,-0.52]$ \\
\hline $\begin{array}{l}\text { 6.1 Fluticasone versus Salme- } \\
\text { terol }\end{array}$ & 3 & 1434 & Mean Difference (Fixed, 95\% Cl) & $-10.88[-32.62,10.87]$ \\
\hline $\begin{array}{l}\text { 6.2 Budesonide versus For- } \\
\text { moterol }\end{array}$ & 1 & 559 & Mean Difference (Fixed, 95\% Cl) & $-40.0[-73.00,-5.00]$ \\
\hline 7 Post-dose FEV1 & 2 & & Mean Difference (Fixed, 95\% Cl) & Totals not selected \\
\hline $\begin{array}{l}\text { 7.1 Fluticasone versus Salme- } \\
\text { terol }\end{array}$ & 1 & & Mean Difference (Fixed, 95\% Cl) & $0.0[0.0,0.0]$ \\
\hline $\begin{array}{l}7.2 \text { Budesonide versus For- } \\
\text { moterol }\end{array}$ & 1 & & Mean Difference (Fixed, 95\% Cl) & $0.0[0.0,0.0]$ \\
\hline 8 Mild exacerbations & 2 & & Odds Ratio (M-H, Fixed, 95\% Cl) & Subtotals only \\
\hline $\begin{array}{l}\text { 8.1 Fluticasone versus Salme- } \\
\text { terol }\end{array}$ & 2 & 688 & Odds Ratio (M-H, Fixed, 95\% Cl) & $1.51[0.74,3.08]$ \\
\hline 9 Mortality & 7 & 5997 & $\begin{array}{l}\text { Peto Odds Ratio (Peto, Fixed, 95\% } \\
\mathrm{Cl} \text { ) }\end{array}$ & $1.17[0.97,1.42]$ \\
\hline $\begin{array}{l}9.1 \text { Fluticasone versus Salme- } \\
\text { terol }\end{array}$ & 4 & 4527 & $\begin{array}{l}\text { Peto Odds Ratio (Peto, Fixed, 95\% } \\
\mathrm{Cl} \text { ) }\end{array}$ & $1.23[1.01,1.51]$ \\
\hline $\begin{array}{l}9.2 \text { Budesonide versus For- } \\
\text { moterol }\end{array}$ & 3 & 1470 & $\begin{array}{l}\text { Peto Odds Ratio (Peto, Fixed, 95\% } \\
\mathrm{Cl} \text { ) }\end{array}$ & $0.62[0.31,1.22]$ \\
\hline $\begin{array}{l}10 \text { Health-related quality of life } \\
\text { SGRQ }\end{array}$ & 3 & 4398 & Mean Difference (Fixed, 95\% Cl) & $-0.74[-1.42,-0.06]$ \\
\hline $\begin{array}{l}10.1 \text { Fluticasone versus Salme- } \\
\text { terol }\end{array}$ & 2 & 3839 & Mean Difference (Fixed, 95\% Cl) & $-0.77[-1.49,-0.04]$ \\
\hline $\begin{array}{l}\text { 10.2 Budesonide versus For- } \\
\text { moterol }\end{array}$ & 1 & 559 & Mean Difference (Fixed, 95\% Cl) & $-0.51[-2.63,1.61]$ \\
\hline
\end{tabular}




\begin{tabular}{|c|c|c|c|c|}
\hline Outcome or subgroup title & No. of studies & $\begin{array}{l}\text { No. of partici- } \\
\text { pants }\end{array}$ & Statistical method & Effect size \\
\hline $\begin{array}{l}11 \text { Dyspnoea symptom score } \\
0-4\end{array}$ & 3 & 1817 & Mean Difference (Fixed, 95\% Cl) & $0.03[-0.02,0.08]$ \\
\hline $\begin{array}{l}11.1 \text { Fluticasone versus Salme- } \\
\text { terol }\end{array}$ & 1 & 746 & Mean Difference (Fixed, 95\% Cl) & $-0.01[-0.08,0.06]$ \\
\hline $\begin{array}{l}\text { 11.2 Budesonide versus For- } \\
\text { moterol }\end{array}$ & 2 & 1071 & Mean Difference (Fixed, 95\% CI) & $0.07[-0.00,0.14]$ \\
\hline 12 Dyspnoea TDI & 2 & & Mean Difference (Fixed, 95\% CI) & Subtotals only \\
\hline $\begin{array}{l}\text { 12.1 Fluticasone versus Salme- } \\
\text { terol }\end{array}$ & 2 & 688 & Mean Difference (Fixed, 95\% CI) & $0.26[-0.21,0.74]$ \\
\hline 13 Symptoms & 3 & 1470 & $\begin{array}{l}\text { Mean Difference (Random, 95\% } \\
\mathrm{Cl} \text { ) }\end{array}$ & $0.22[-0.03,0.47]$ \\
\hline $\begin{array}{l}\text { 13.1 Budesonide versus For- } \\
\text { moterol }\end{array}$ & 3 & 1470 & $\begin{array}{l}\text { Mean Difference (Random, 95\% } \\
\mathrm{Cl} \text { ) }\end{array}$ & $0.22[-0.03,0.47]$ \\
\hline 14 Adverse events & 5 & 5089 & Odds Ratio (M-H, Fixed, 95\% Cl) & $1.12[0.96,1.30]$ \\
\hline $\begin{array}{l}\text { 14.1 Fluticasone versus Salme- } \\
\text { terol }\end{array}$ & 4 & 4530 & Odds Ratio (M-H, Fixed, 95\% Cl) & $1.14[0.96,1.35]$ \\
\hline $\begin{array}{l}\text { 14.2 Budesonide versus For- } \\
\text { moterol }\end{array}$ & 1 & 559 & Odds Ratio (M-H, Fixed, 95\% Cl) & $1.03[0.74,1.44]$ \\
\hline $\begin{array}{l}15 \text { Serious adverse events } \\
\text { (non-fatal) }\end{array}$ & 6 & & $\begin{array}{l}\text { Odds Ratio (M-H, Random, 95\% } \\
\mathrm{Cl} \text { ) }\end{array}$ & Subtotals only \\
\hline $\begin{array}{l}\text { 15.1 Budesonide versus For- } \\
\text { moterol number of SAEs }\end{array}$ & 3 & 1470 & $\begin{array}{l}\text { Odds Ratio (M-H, Random, 95\% } \\
\mathrm{Cl} \text { ) }\end{array}$ & $1.01[0.77,1.31]$ \\
\hline $\begin{array}{l}15.2 \text { Fluticasone versus Salme- } \\
\text { terol number of patients with } \\
1 \text { or more SAEs }\end{array}$ & 3 & 1436 & $\begin{array}{l}\text { Odds Ratio (M-H, Random, 95\% } \\
\mathrm{Cl} \text { ) }\end{array}$ & $1.17[0.60,2.28]$ \\
\hline 16 Withdrawals & 7 & 5961 & Odds Ratio (M-H, Fixed, 95\% Cl) & $1.02[0.92,1.14]$ \\
\hline $\begin{array}{l}\text { 16.1 Fluticasone versus Salme- } \\
\text { terol }\end{array}$ & 4 & 4491 & Odds Ratio (M-H, Fixed, 95\% Cl) & $1.05[0.92,1.18]$ \\
\hline $\begin{array}{l}\text { 16.2 Budesonide versus For- } \\
\text { moterol }\end{array}$ & 3 & 1470 & Odds Ratio (M-H, Fixed, 95\% Cl) & $0.96[0.76,1.20]$ \\
\hline
\end{tabular}


Analysis 1.1. Comparison 1 Inhaled corticosteroids (ICS) versus long-acting beta $_{2}$-agonists (LABA) by ICS and LABA, Outcome 1 Exacerbation rate ratios.

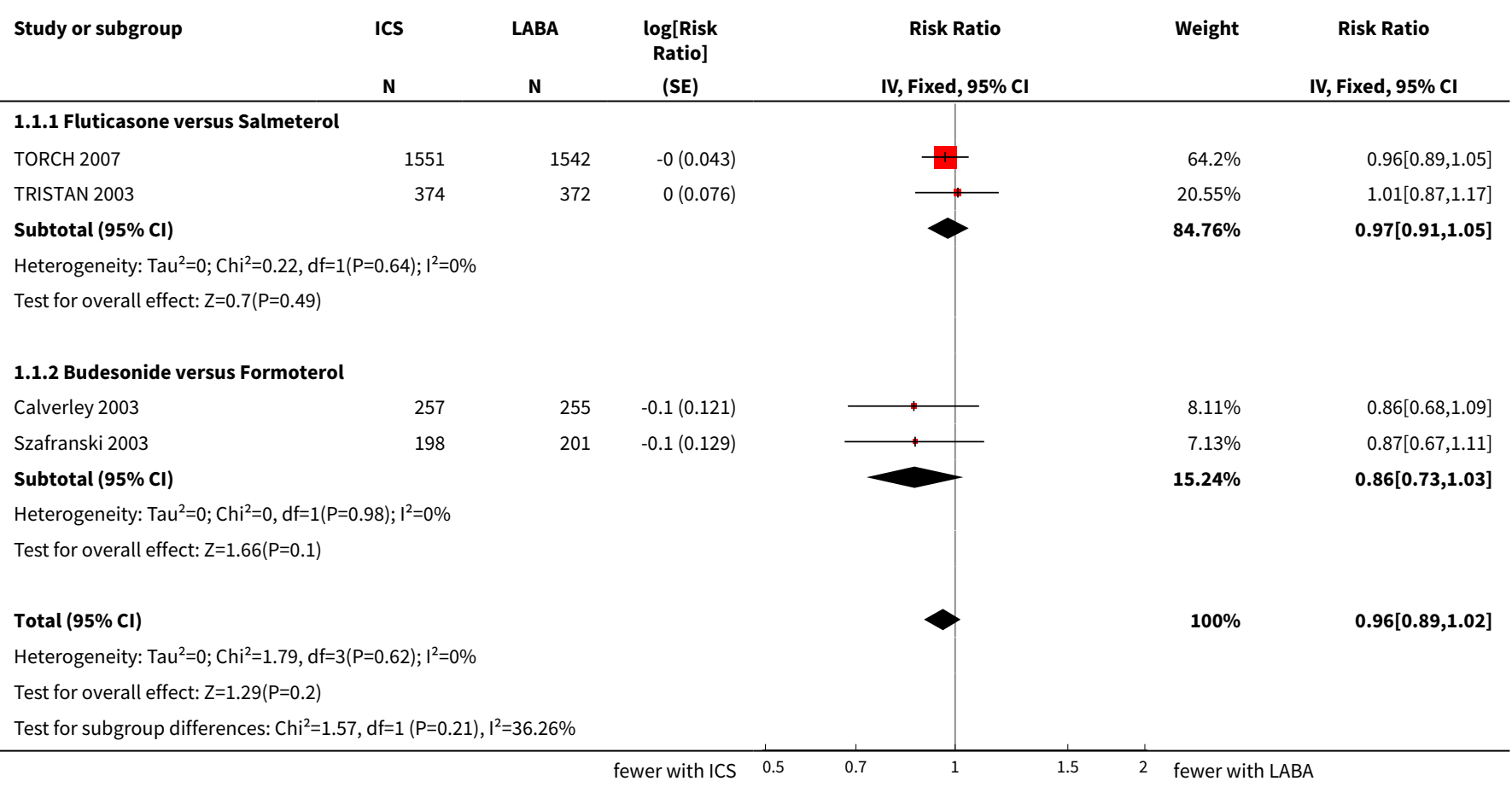

Analysis 1.2. Comparison 1 Inhaled corticosteroids (ICS) versus longacting beta 2 -agonists (LABA) by ICS and LABA, Outcome 2 Exacerbations.

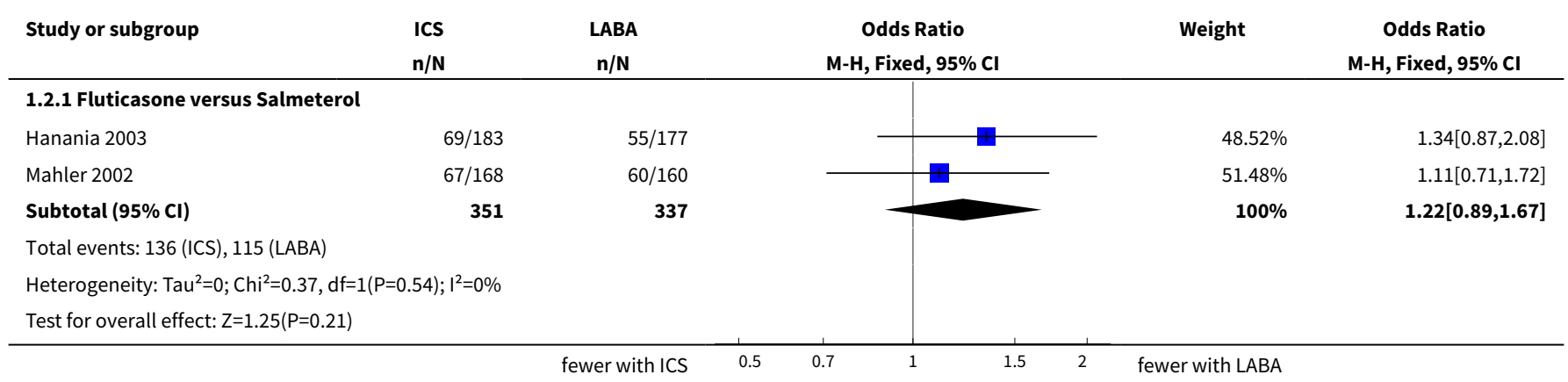

Analysis 1.3. Comparison 1 Inhaled corticosteroids (ICS) versus long-acting beta - $^{-}$ agonists (LABA) by ICS and LABA, Outcome 3 Hospitalisations due to exacerbations.

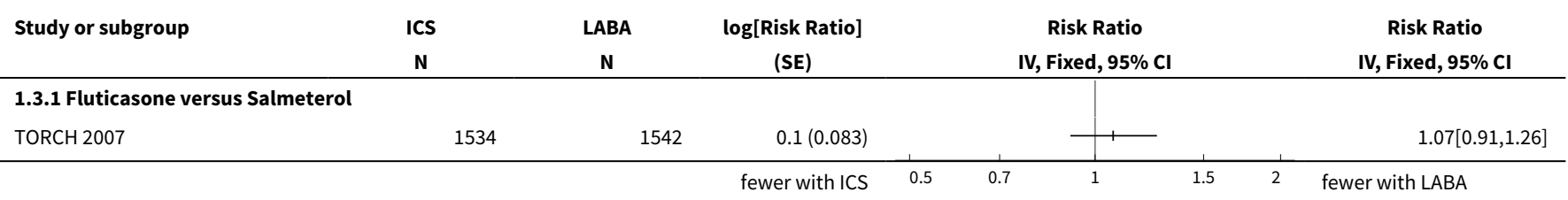


Analysis 1.4. Comparison 1 Inhaled corticosteroids (ICS) versus long-acting beta $_{2}$-agonists (LABA) by ICS and LABA, Outcome 4 Pneumonia adverse event.

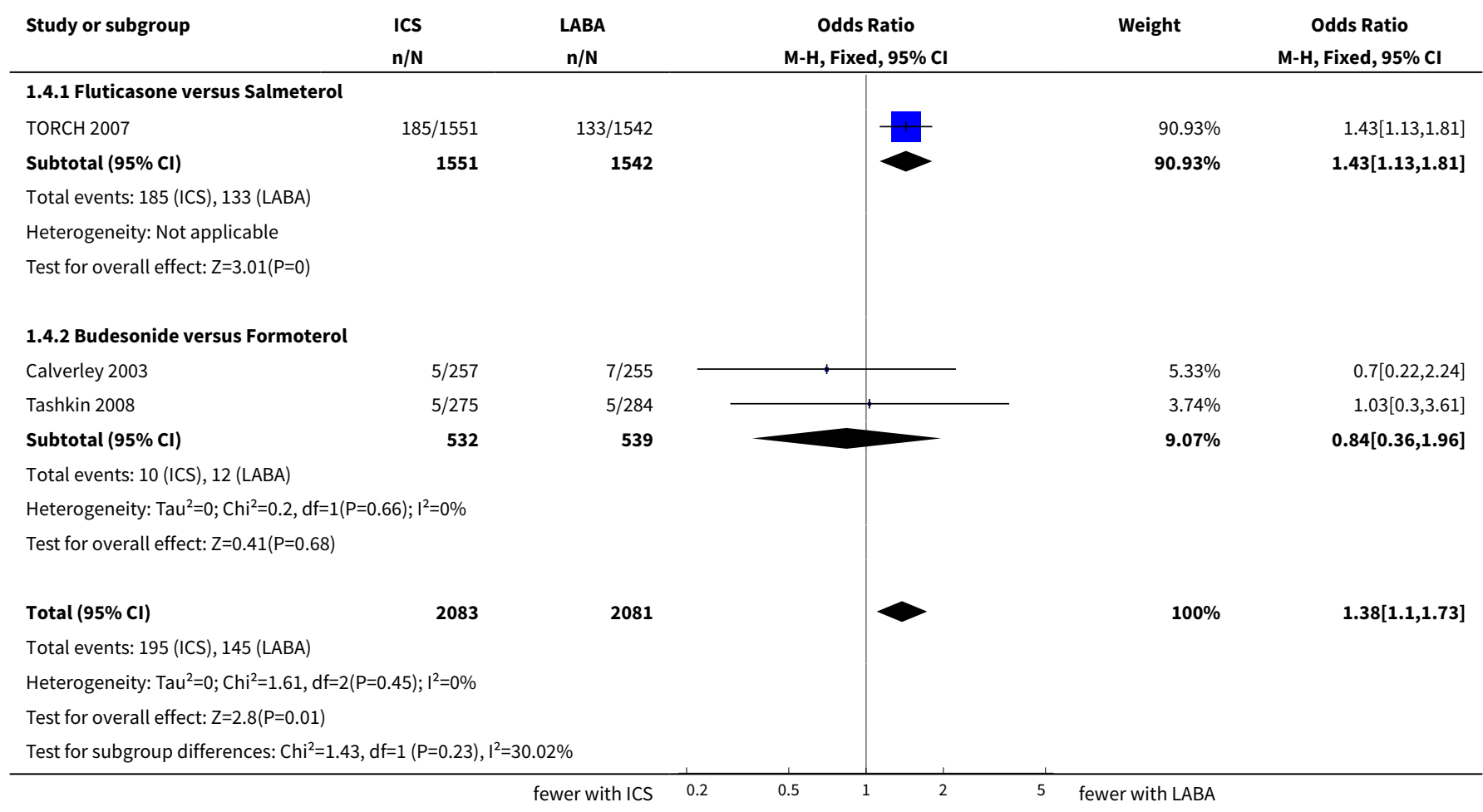

Analysis 1.5. Comparison 1 Inhaled corticosteroids (ICS) versus long-acting beta 2agonists (LABA) by ICS and LABA, Outcome 5 Pneumonia serious adverse event.

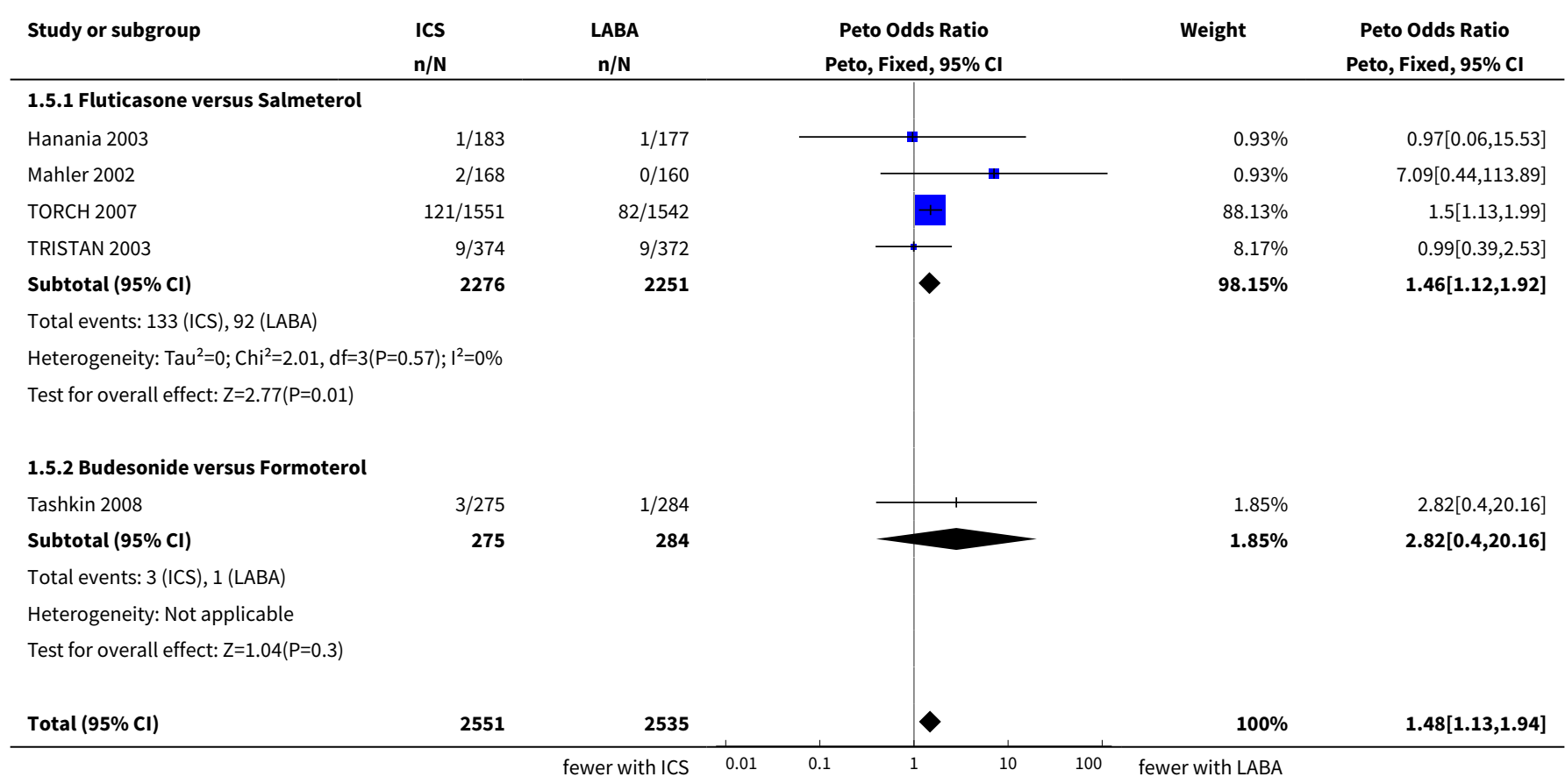




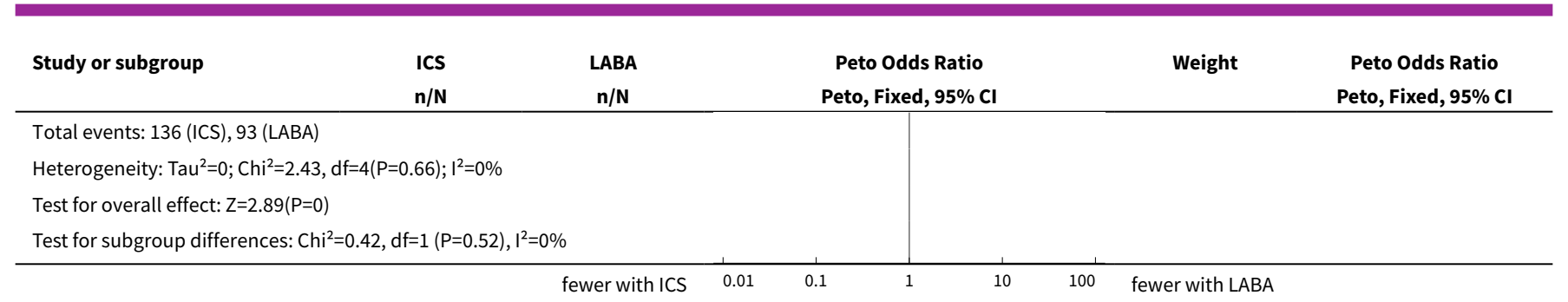

Analysis 1.6. Comparison 1 Inhaled corticosteroids (ICS) versus longacting beta ${ }_{2}$-agonists (LABA) by ICS and LABA, Outcome 6 Pre-dose FEV1.

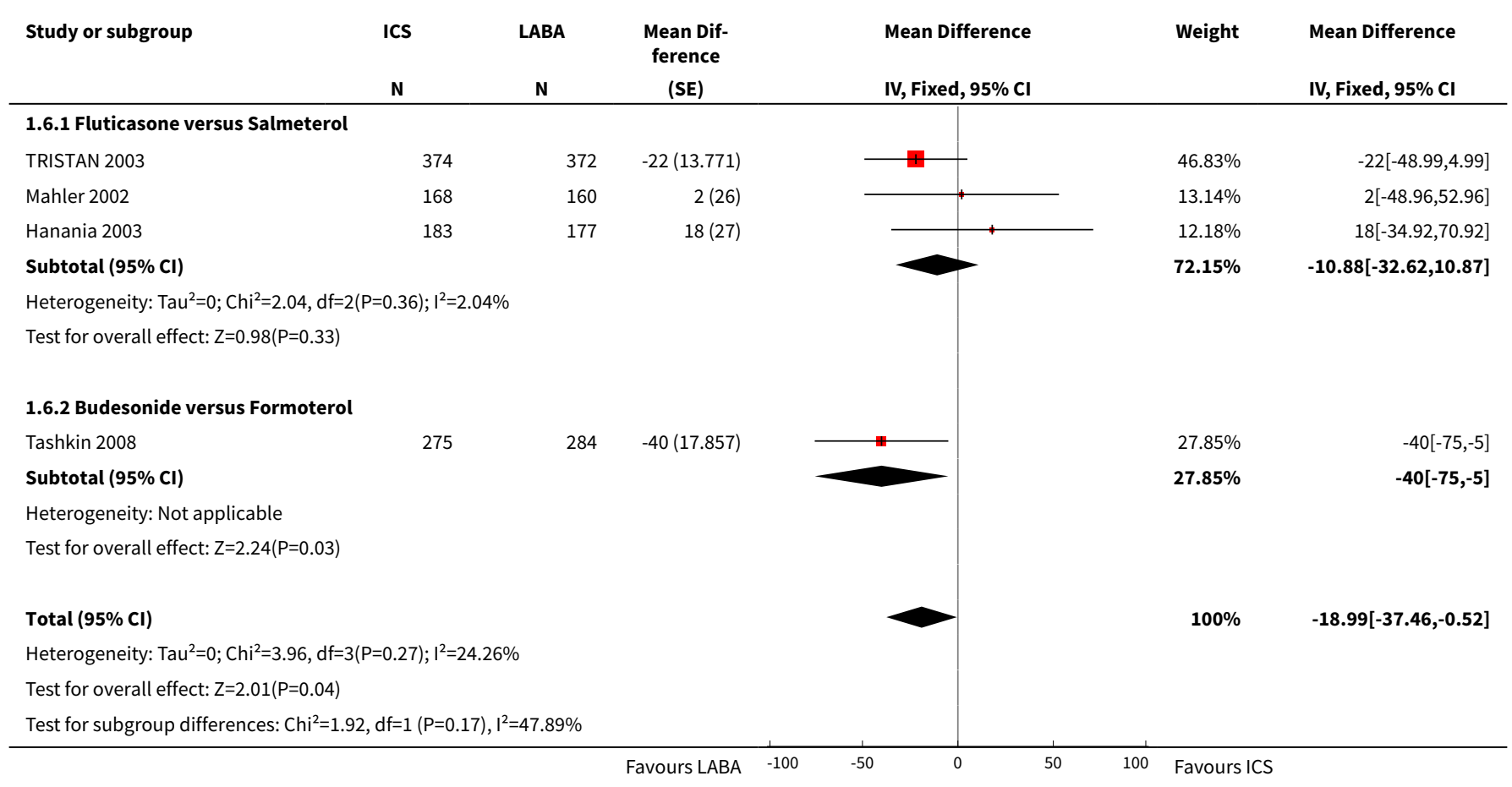

Analysis 1.7. Comparison 1 Inhaled corticosteroids (ICS) versus longacting beta ${ }_{2}$-agonists (LABA) by ICS and LABA, Outcome 7 Post-dose FEV1.

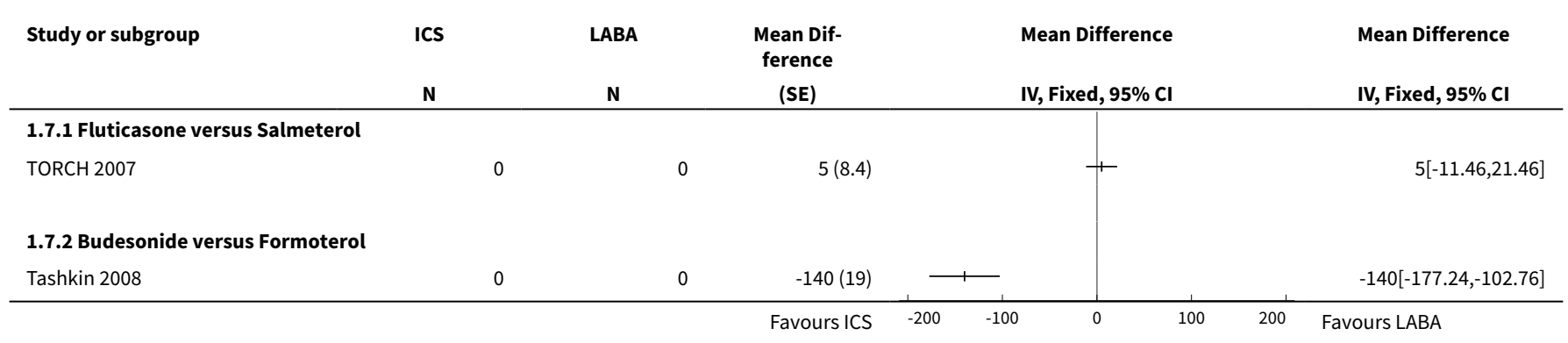


Analysis 1.8. Comparison 1 Inhaled corticosteroids (ICS) versus longacting beta ${ }_{2}$-agonists (LABA) by ICS and LABA, Outcome 8 Mild exacerbations.

\begin{tabular}{|c|c|c|c|c|c|}
\hline Study or subgroup & $\begin{array}{l}\text { ICS } \\
\mathrm{n} / \mathrm{N} \\
\end{array}$ & $\begin{array}{l}\text { LABA } \\
\mathrm{n} / \mathrm{N}\end{array}$ & $\begin{array}{c}\text { Odds Ratio } \\
\text { M-H, Fixed, } 95 \% \text { Cl }\end{array}$ & Weight & $\begin{array}{c}\text { Odds Ratio } \\
\text { M-H, Fixed, 95\% Cl }\end{array}$ \\
\hline \multicolumn{6}{|c|}{ 1.8.1 Fluticasone versus Salmeterol } \\
\hline Hanania 2003 & $10 / 183$ & $10 / 177$ & - & $76.88 \%$ & $0.97[0.39,2.38]$ \\
\hline Mahler 2002 & $10 / 168$ & $3 / 160$ & & $23.12 \%$ & $3.31[0.89,12.26]$ \\
\hline Subtotal $(95 \% \mathrm{CI})$ & 351 & 337 & & $100 \%$ & $1.51[0.74,3.08]$ \\
\hline \multicolumn{6}{|c|}{ Total events: 20 (ICS), 13 (LABA) } \\
\hline \multicolumn{6}{|c|}{ Test for overall effect: $Z=1.13(P=0.26)$} \\
\hline
\end{tabular}

Analysis 1.9. Comparison 1 Inhaled corticosteroids (ICS) versus longacting beta 2 -agonists (LABA) by ICS and LABA, Outcome 9 Mortality.

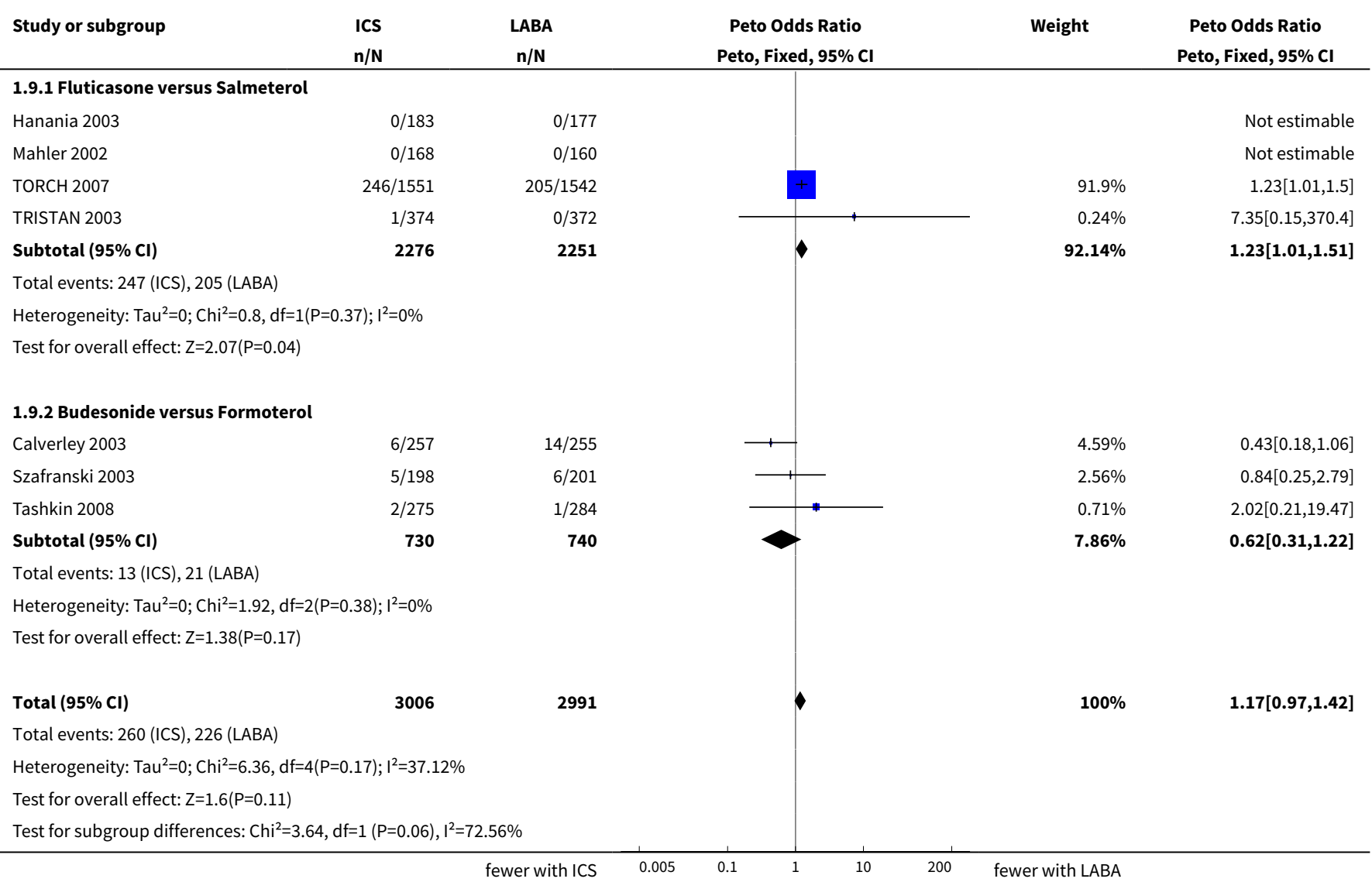




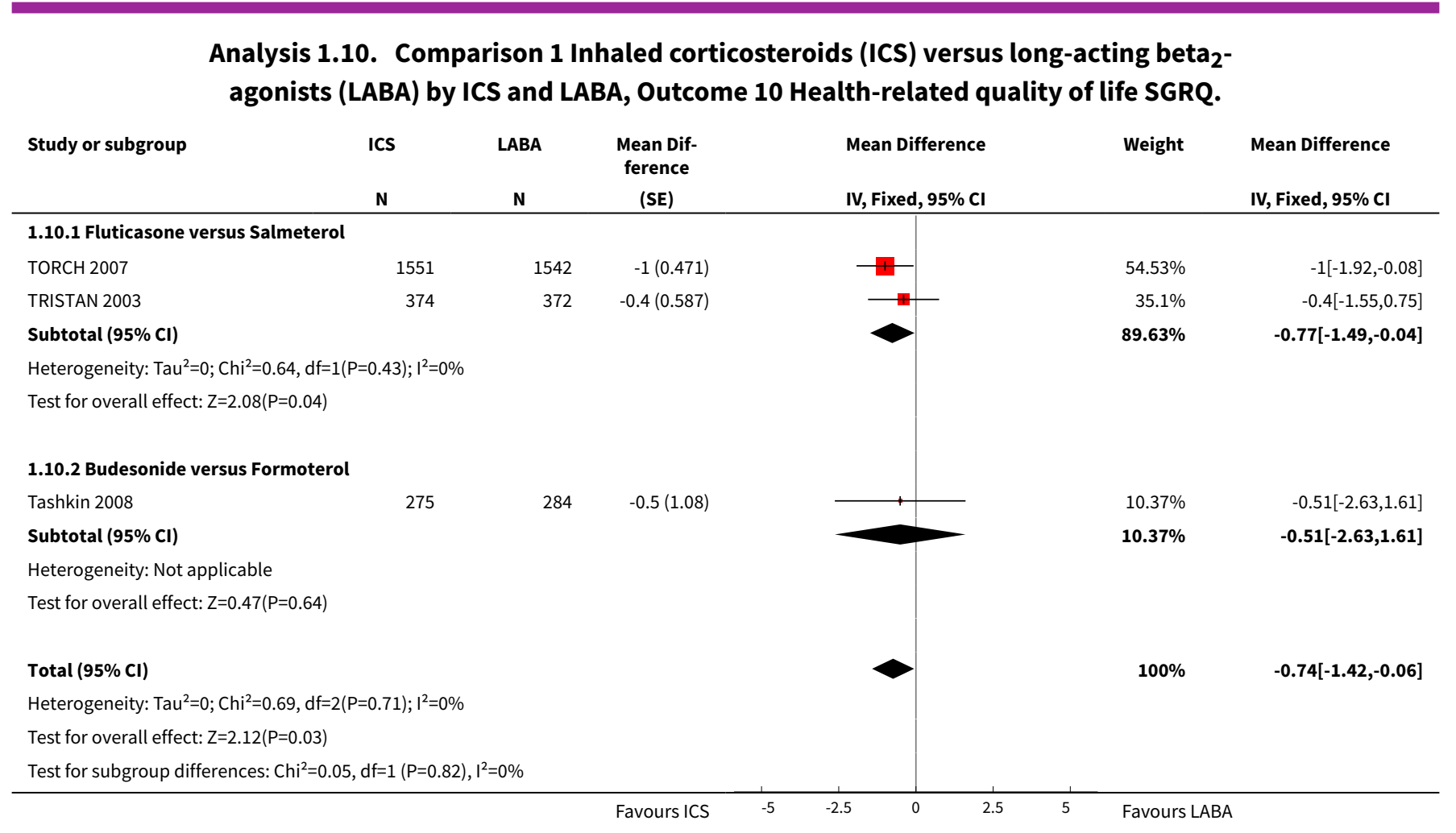

Analysis 1.11. Comparison 1 Inhaled corticosteroids (ICS) versus long-acting beta $_{2}$-agonists (LABA) by ICS and LABA, Outcome 11 Dyspnoea symptom score 0-4.

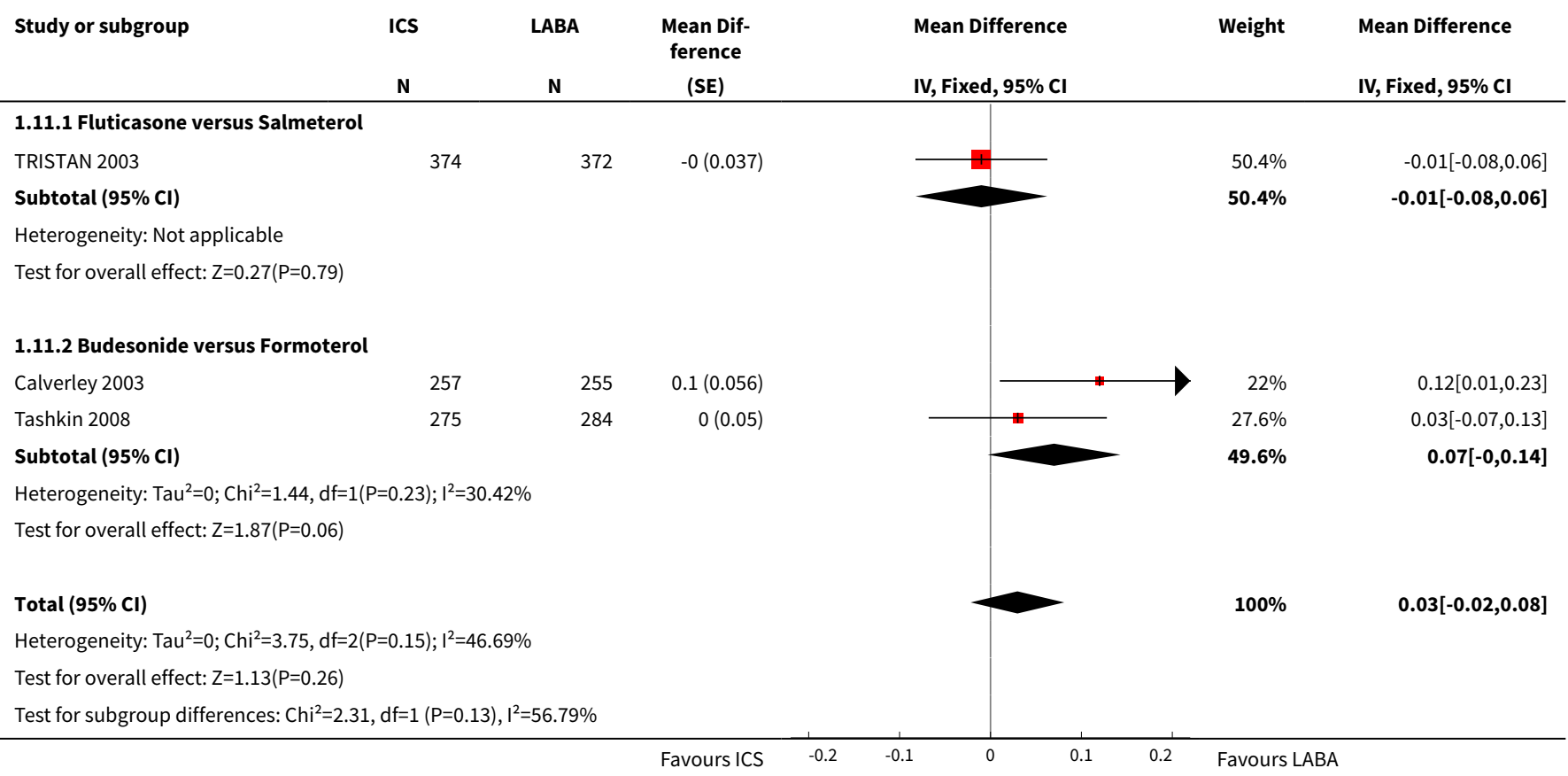


Analysis 1.12. Comparison 1 Inhaled corticosteroids (ICS) versus longacting beta ${ }_{2}$-agonists (LABA) by ICS and LABA, Outcome 12 Dyspnoea TDI.

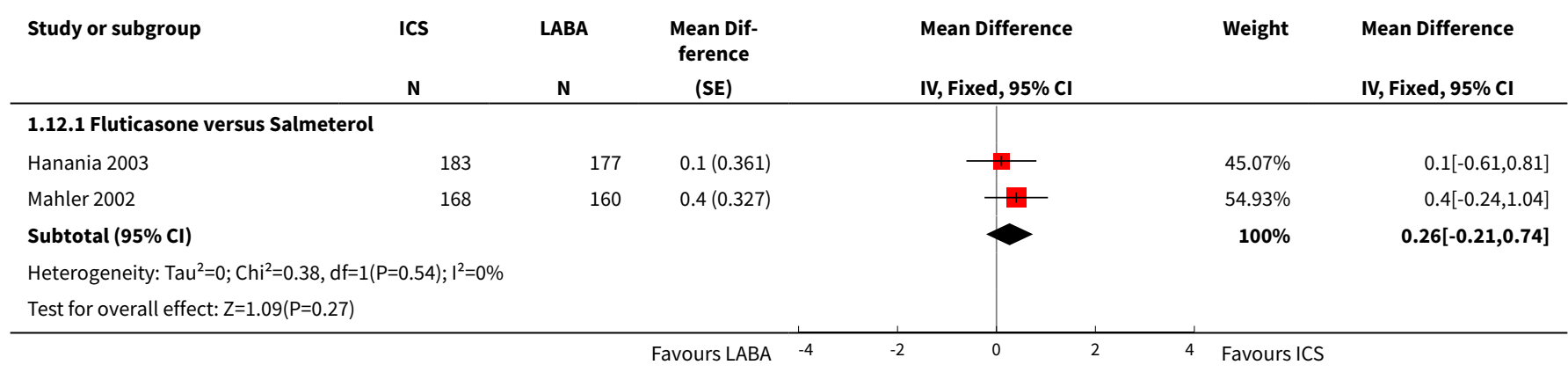

Analysis 1.13. Comparison 1 Inhaled corticosteroids (ICS) versus longacting beta ${ }_{2}$-agonists (LABA) by ICS and LABA, Outcome 13 Symptoms.

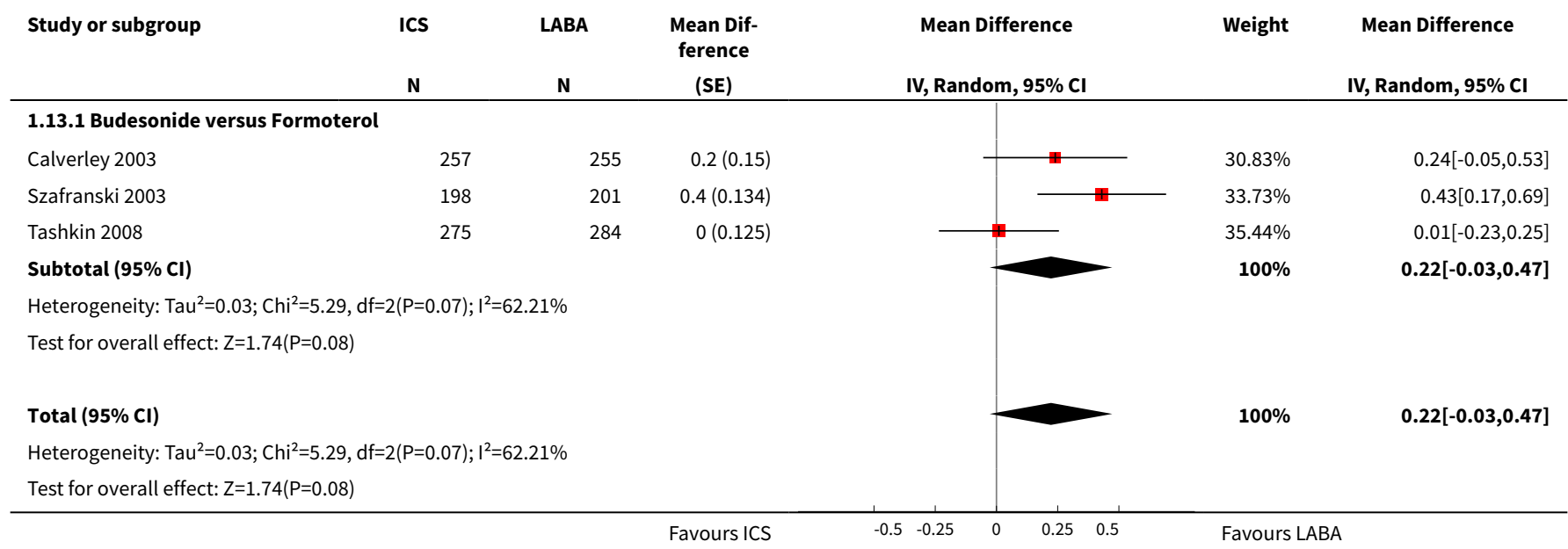

Analysis 1.14. Comparison 1 Inhaled corticosteroids (ICS) versus longacting beta ${ }_{2}$-agonists (LABA) by ICS and LABA, Outcome 14 Adverse events.

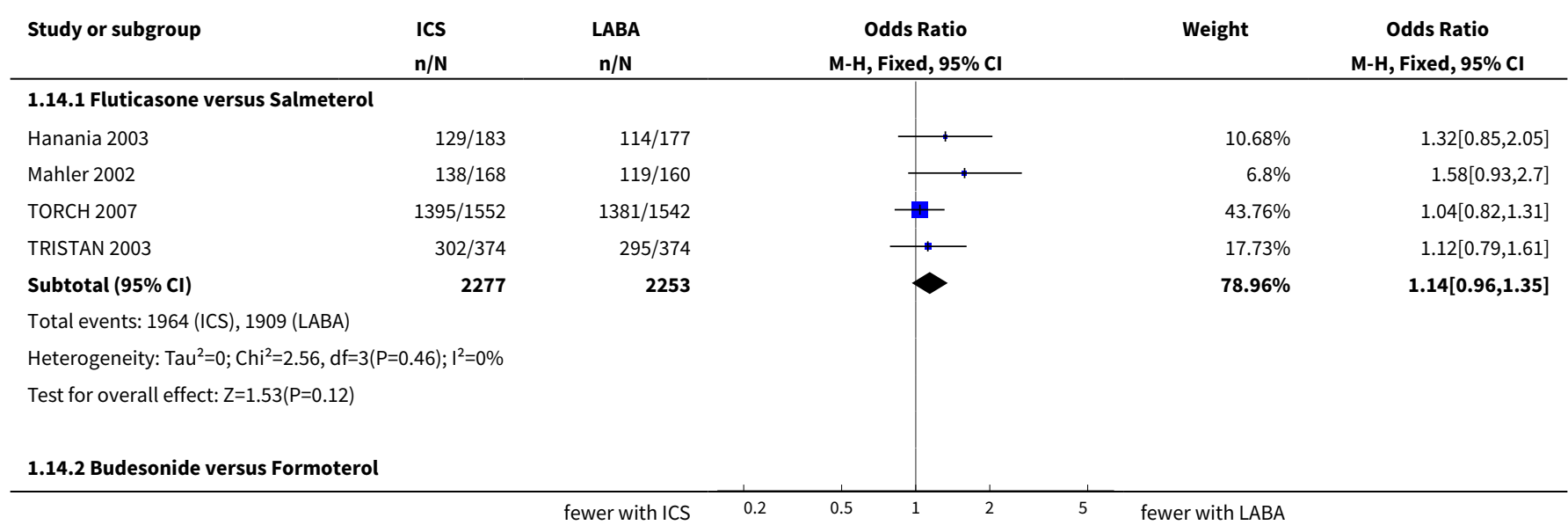




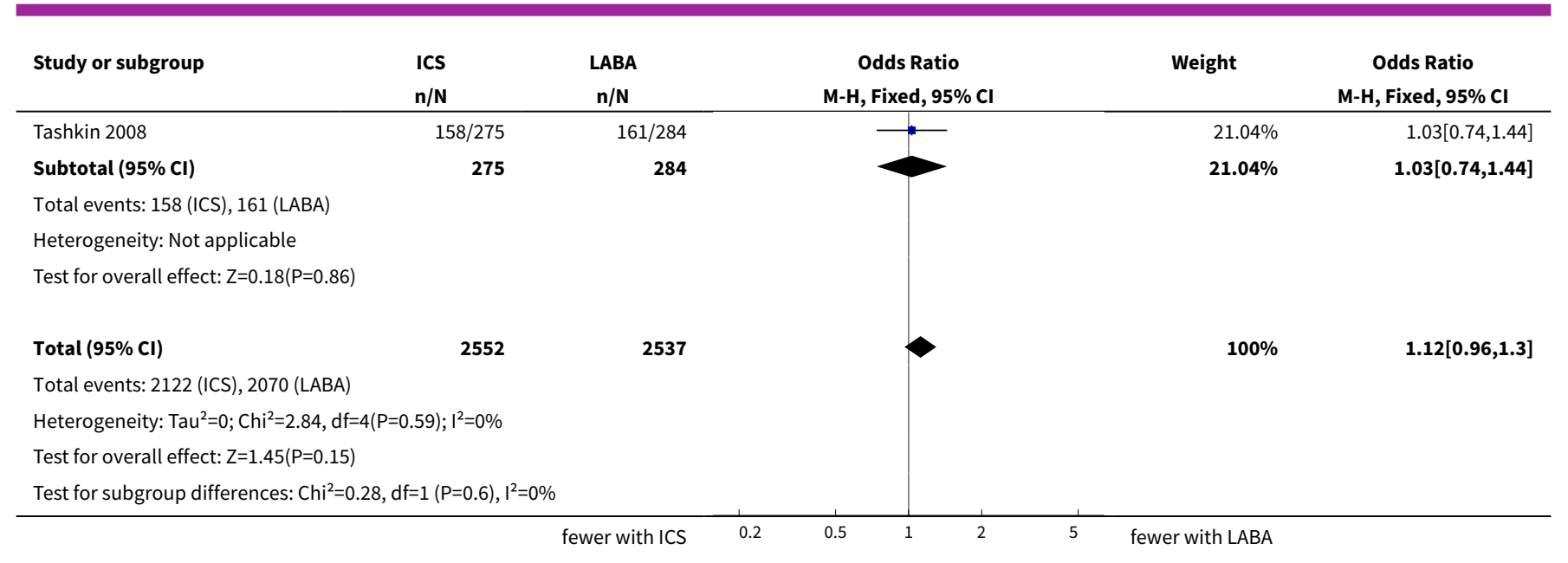

\section{Analysis 1.15. Comparison 1 Inhaled corticosteroids (ICS) versus long-acting beta 2- $^{-}$ agonists (LABA) by ICS and LABA, Outcome 15 Serious adverse events (non-fatal).}

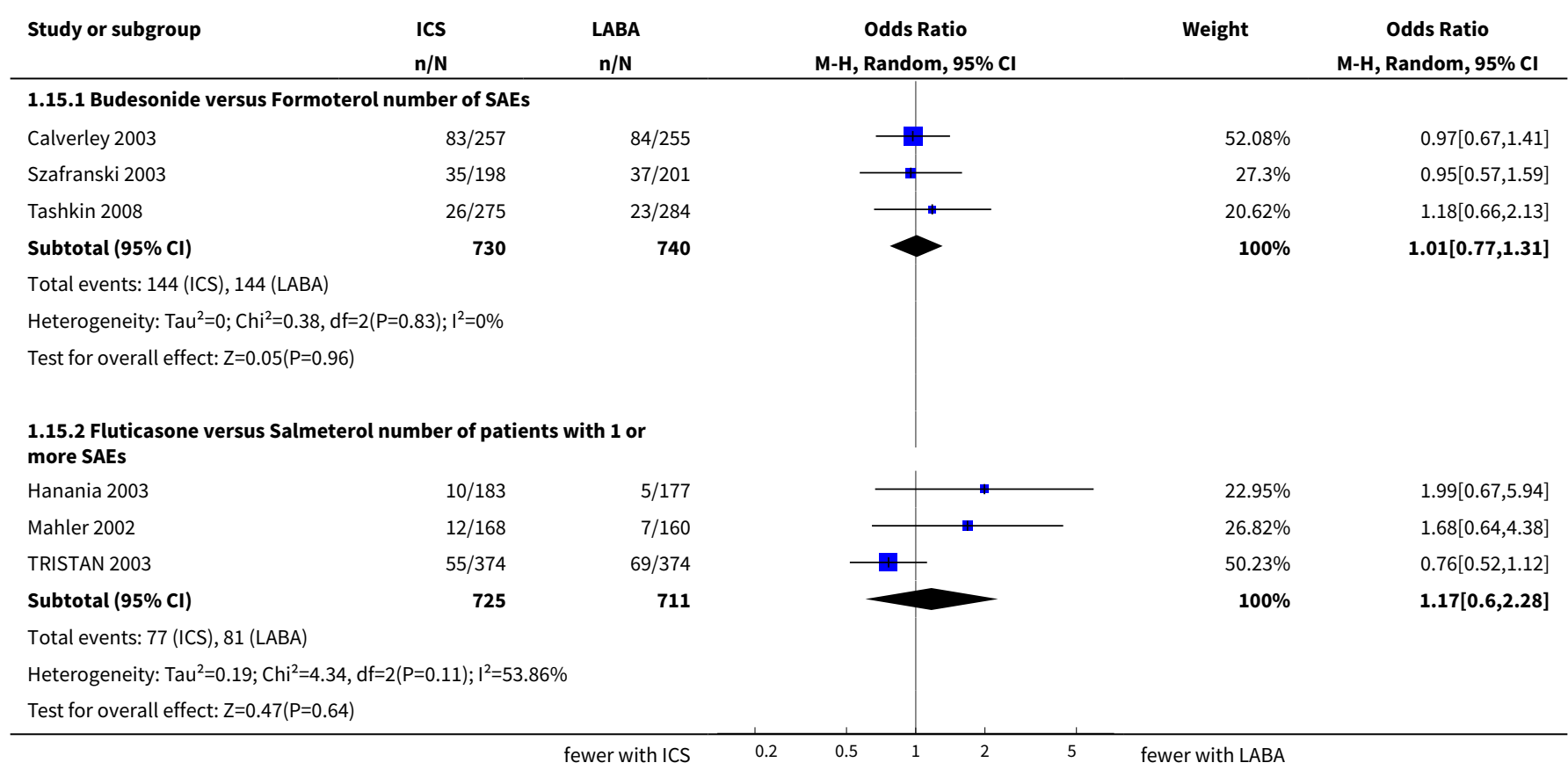

Analysis 1.16. Comparison 1 Inhaled corticosteroids (ICS) versus longacting beta ${ }_{2}$-agonists (LABA) by ICS and LABA, Outcome 16 Withdrawals.

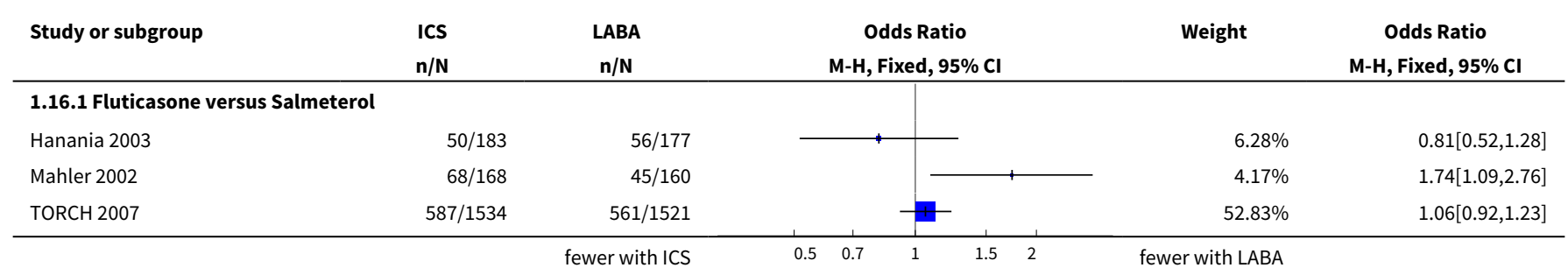




\begin{tabular}{|c|c|c|c|c|c|}
\hline Study or subgroup & $\begin{array}{l}\text { ICS } \\
\mathrm{n} / \mathrm{N}\end{array}$ & $\begin{array}{l}\text { LABA } \\
n / N\end{array}$ & $\begin{array}{c}\text { Odds Ratio } \\
\text { M-H, Fixed, } 95 \% \mathrm{Cl}\end{array}$ & Weight & $\begin{array}{c}\text { Odds Ratio } \\
\text { M-H, Fixed, } 95 \% \mathrm{Cl}\end{array}$ \\
\hline TRISTAN 2003 & $108 / 374$ & $119 / 374$ & $\longrightarrow+1$ & $12.86 \%$ & $0.87[0.64,1.19]$ \\
\hline Subtotal $(95 \% \mathrm{Cl})$ & 2259 & 2232 & & $76.14 \%$ & $1.05[0.92,1.18]$ \\
\hline \multicolumn{6}{|c|}{ Total events: 813 (ICS), 781 (LABA) } \\
\hline \multicolumn{6}{|c|}{ Heterogeneity: $\mathrm{Tau}^{2}=0 ; \mathrm{Chi}^{2}=7.2, \mathrm{df}=3(\mathrm{P}=0.07) ; \mathrm{I}^{2}=58.32 \%$} \\
\hline \multicolumn{6}{|c|}{ Test for overall effect: $Z=0.71(P=0.48)$} \\
\hline \multicolumn{6}{|c|}{ 1.16.2 Budesonide versus Formoterol } \\
\hline Calverley 2003 & $102 / 257$ & $111 / 255$ & - & $10.21 \%$ & $0.85[0.6,1.21]$ \\
\hline Szafranski 2003 & $62 / 198$ & $64 / 201$ & & $6.63 \%$ & $0.98[0.64,1.49]$ \\
\hline Tashkin 2008 & $63 / 275$ & $61 / 284$ & 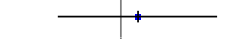 & $7.03 \%$ & $1.09[0.73,1.62]$ \\
\hline Subtotal $(95 \% \mathrm{Cl})$ & 730 & 740 & & $23.86 \%$ & $0.96[0.76,1.2]$ \\
\hline \multicolumn{6}{|c|}{ Total events: 227 (ICS), 236 (LABA) } \\
\hline \multicolumn{6}{|c|}{ Heterogeneity: $\operatorname{Tau}^{2}=0 ; \mathrm{Chi}^{2}=0.8, \mathrm{df}=2(\mathrm{P}=0.67) ; \mathrm{I}^{2}=0 \%$} \\
\hline \multicolumn{6}{|c|}{ Test for overall effect: $Z=0.39(P=0.69)$} \\
\hline Total $(95 \% \mathrm{Cl})$ & 2989 & 2972 & & $100 \%$ & $1.02[0.92,1.14]$ \\
\hline \multicolumn{6}{|c|}{ Total events: 1040 (ICS), 1017 (LABA) } \\
\hline \multicolumn{6}{|c|}{ Heterogeneity: $\operatorname{Tau}^{2}=0 ; \mathrm{Chi}^{2}=8.46, \mathrm{df}=6(\mathrm{P}=0.21) ; \mathrm{I}^{2}=29.08 \%$} \\
\hline \multicolumn{6}{|c|}{ Test for overall effect: $Z=0.43(P=0.67)$} \\
\hline \multicolumn{6}{|c|}{ Test for subgroup differences: $\mathrm{Chi}^{2}=0.47, \mathrm{df}=1(\mathrm{P}=0.49), \mathrm{I}^{2}=0 \%$} \\
\hline
\end{tabular}

\section{Comparison 2. Inhaled corticosteroids versus long-acting beta ${ }_{2}$-agonists by length of study}

\begin{tabular}{|c|c|c|c|c|}
\hline Outcome or subgroup title & No. of studies & $\begin{array}{l}\text { No. of partici- } \\
\text { pants }\end{array}$ & Statistical method & Effect size \\
\hline 1 Exacerbation rate ratios & 4 & 4750 & Risk Ratio (Fixed, 95\% Cl) & $0.96[0.89,1.02]$ \\
\hline 1.1 up to 1 year & 3 & 1657 & Risk Ratio (Fixed, 95\% Cl) & $0.94[0.84,1.05]$ \\
\hline 1.2 longer than 1 year & 1 & 3093 & Risk Ratio (Fixed, 95\% Cl) & $0.96[0.89,1.05]$ \\
\hline $\begin{array}{l}2 \text { Pneumonia serious ad- } \\
\text { verse event }\end{array}$ & 6 & 5560 & $\begin{array}{l}\text { Peto Odds Ratio (Peto, Fixed, 95\% } \\
\mathrm{Cl} \text { ) }\end{array}$ & $1.42[1.10,1.85]$ \\
\hline 2.1 up to 1 year & 5 & 2505 & $\begin{array}{l}\text { Peto Odds Ratio (Peto, Fixed, 95\% } \\
\mathrm{Cl} \text { ) }\end{array}$ & $1.11[0.58,2.10]$ \\
\hline 2.2 longer than 1 year & 1 & 3055 & $\begin{array}{l}\text { Peto Odds Ratio (Peto, Fixed, 95\% } \\
\mathrm{Cl} \text { ) }\end{array}$ & $1.50[1.12,1.99]$ \\
\hline
\end{tabular}


Analysis 2.1. Comparison 2 Inhaled corticosteroids versus long-acting beta $_{2}$-agonists by length of study, Outcome 1 Exacerbation rate ratios.

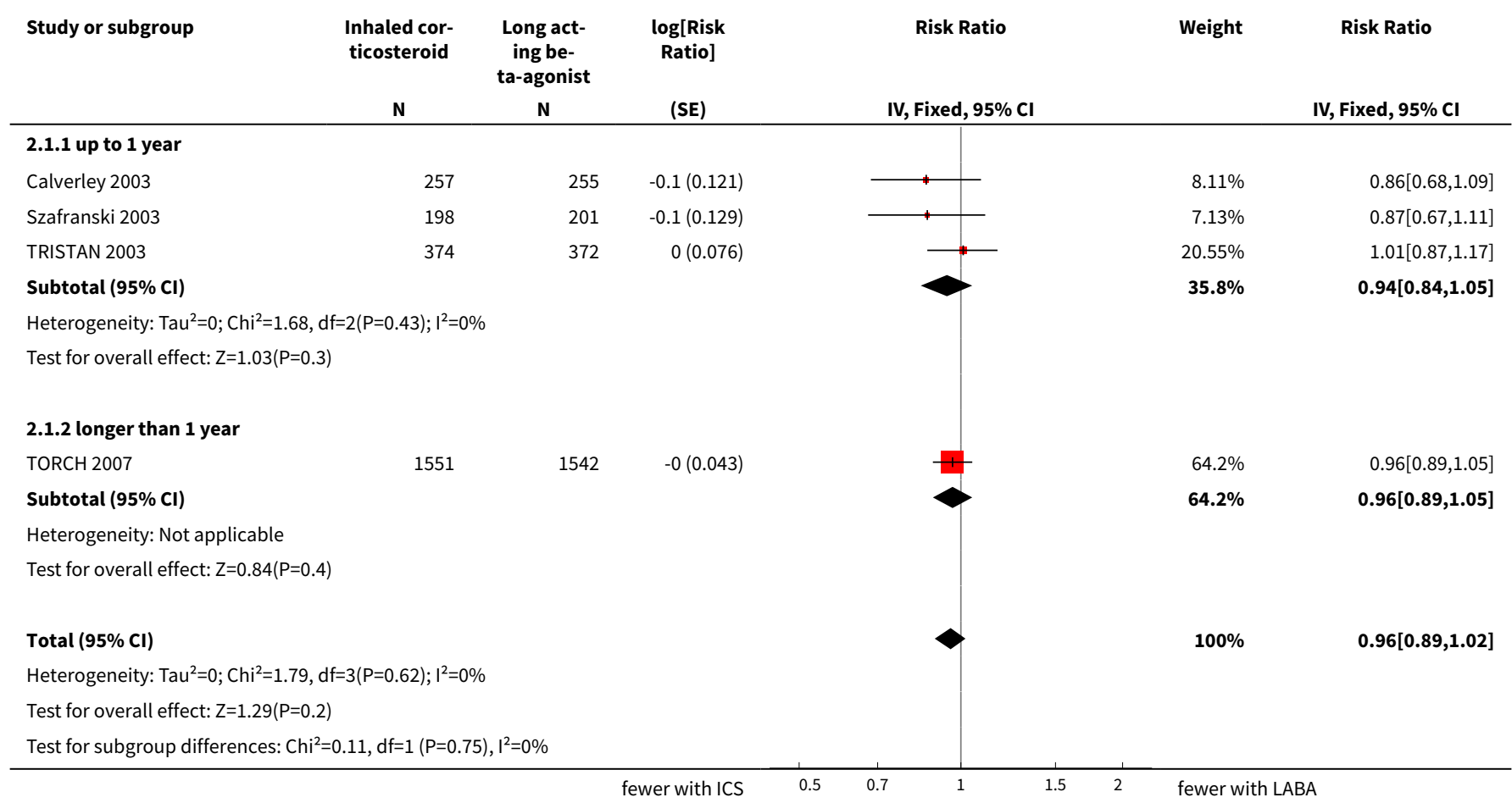

\section{Analysis 2.2. Comparison 2 Inhaled corticosteroids versus long-acting beta ${ }_{2}$ - agonists by length of study, Outcome 2 Pneumonia serious adverse event.}

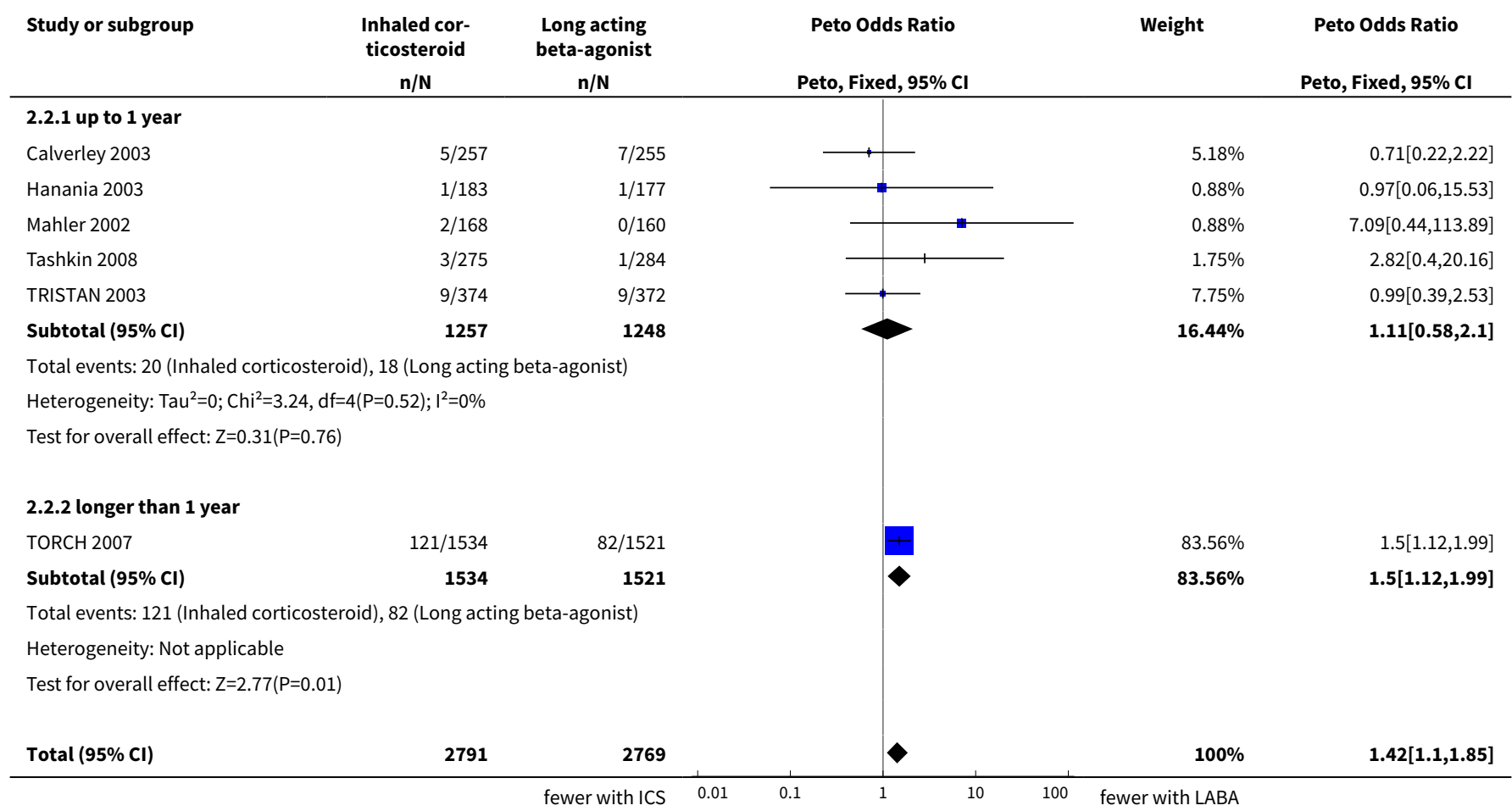




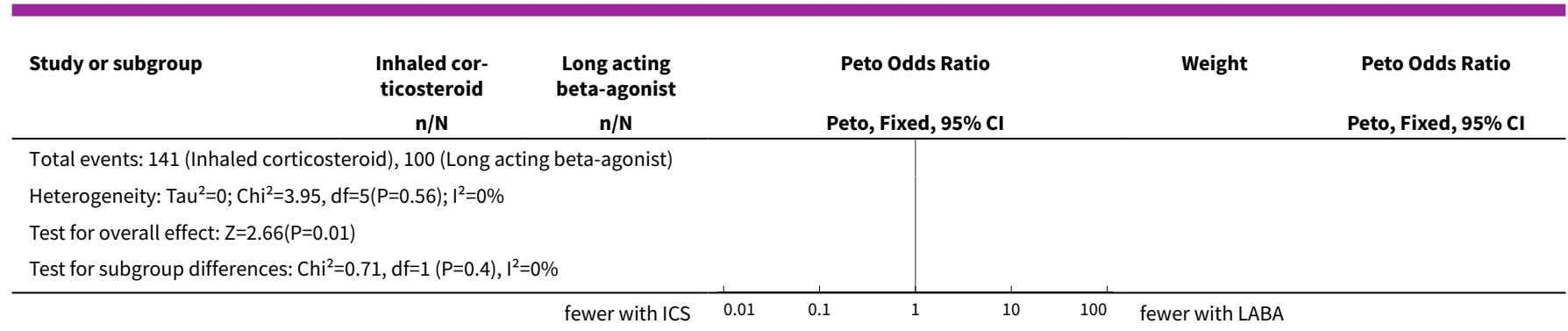

\section{ADDITIONAL TABLES}

Table 1. Excluded data

\begin{tabular}{|c|c|c|c|c|c|c|}
\hline & $\begin{array}{l}\text { Calverley } \\
2003\end{array}$ & $\begin{array}{l}\text { Hanania } \\
2003\end{array}$ & $\begin{array}{l}\text { Mahler } \\
2002\end{array}$ & $\begin{array}{l}\text { Szafranski } \\
2003\end{array}$ & $\begin{array}{l}\text { Tashkin } \\
2008\end{array}$ & $\begin{array}{l}\text { TRISTAN } \\
2003\end{array}$ \\
\hline Exacerbations & & & & & $x$ & \\
\hline Pre-dose FEV 1 & & $x$ & $x$ & & & \\
\hline Post-dose FEV 1 & $x$ & $x$ & $x$ & & & \\
\hline PEF & $x$ & $x$ & $x$ & $x$ & & $x$ \\
\hline Dyspnoea & & & & $x$ & & \\
\hline Symptom & & $x$ & & & & \\
\hline Rescue medication & & & $x$ & & & \\
\hline
\end{tabular}

\section{AP PEN DICES}

\section{Appendix 1. Data analysis}

None of the included trials directly compared inhaled corticosteroids (ICS) alone to long-acting beta 2 -agonists (LABA) alone for treatment of COPD. However, the studies included these treatment arms which were compared to the treatment effect of ICS/LABA combination treatment and/or placebo. We have used the direct comparison of ICS and LABA where this has been available and complemented this with indirect estimates of treatment effects.

For dichotomous data we obtained the log risk ratio (LRR) for ICS vs LABA from trials comparing either:

ICS/LABA vs ICS and ICS/LABA vs LABA

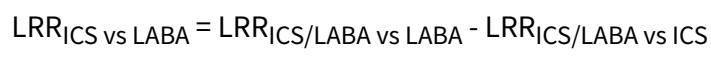

or ICS vs placebo and LABA vs placebo

$\mathrm{LRR}_{\mathrm{ICS}}$ vs $L A B A=\mathrm{LRR}_{\mathrm{ICS}}$ vs placebo $-\mathrm{LRR}_{\mathrm{LABA}}$ vs placebo

For continuous data the indirect estimation of treatment effect of ICS vs LABA was calculated similarly.

The exact standard error (SE) for ICS vs LABA could be calculated when SE or confidence intervals (CI) were available for the following five indirect comparisons: 
ICS/LABA vs placebo

ICS/LABA vs LABA

ICS/LABA vs ICS

LABA vs placebo

ICS vs placebo

The variance (VAR) for ICS vs LABA could then be calculated from:

$\mathrm{ICS} / \mathrm{LABA}=\mathrm{A}$

$\mathrm{ICS}=\mathrm{B}$

$\mathrm{LABA}=\mathrm{C}$

Placebo $=\mathrm{D}$

$V A R_{B C}=\left(V A R_{A B}+V A R_{A C}+V A R_{B D}+V A R_{C D}-2^{*} V A R_{A D}\right) / 2$

When the treatment effect of ICS and LABA were only compared to either ICS/LABA or placebo, but comparisons to both were not available, the variance for ICS vs LABA was calculated through either of following ways:

$V A R_{B C}=V_{A R} A B+V A R_{A C}-V_{A R}$

$V A R_{B C}=V A R_{B D}+V A R_{C D}-V A R_{A D}$

These calculations were only used if exact $\mathrm{P}$ values or $\mathrm{Cl}$ for each comparison were available. We assumed that the contribution of the individual groups to the variance of ICS/LABA vs placebo $\left(V_{A R}\right)$ was equal. When not all reported $P$ values for the different comparisons were exact we assumed that the SE for each comparison was similar to the SE for comparisons with an exact $\mathrm{P}$ value.

\section{FEE D B A C K}

\section{Comments on the assessment of the risk of bias for the TORCH trial, 13 October 2018}

\section{Summary}

We performed a risk of bias assessment for the TORCH trial because it comprised the majority of the data in this review. We disagree with the assessment for blinding and incomplete outcome data. We determined the study had high risk of inadequate blinding because of the unique adverse effects experienced by patients on ICS. The rates of candidiasis and dysphonia were higher in the fluticasone and combination group compared to placebo and salmeterol groups. These are typical adverse effects of ICS and could possibly signify to patients and providers which group the patient belonged to. There is empirical evidence that potential loss of blinding in randomized trials is associated with exaggeration of treatment effects, on average $13 \%$ measured as odds ratio (Savovic 2012).

Another discrepancy is that we disagree with the assessment of attrition bias as low risk. For patients who withdrew from the study, all data on exacerbations, health status, and lung function was only collected until the time of withdrawal. A large proportion of patients withdrew for reasons where data could still have been followed-up on. For example, "lack of efficacy", "adverse event", and "noncompliance with regimen". Ideally, data for these participants should be obtained and included in the analysis since the study claims to have used the intention to treat principle. We concluded high risk of attrition bias due to the high withdrawal rate, because the missing data may have influenced the final outcomes in the TORCH trial. Empirical evidence shows that analyses that excluded patients tended to exaggerate treatment effects compared to those that included all patients (Tierney 2005).

In summary, we suggest reviewing the risk of bias assessments for the TORCH trial.

Nicole Giunio-Zorkin, Ruthdol Ywaya, Elissa Aeng, Aaron Tejani

References

Savović J, Jones HE, Altman DG, Harris RJ, Jüni P, Pildal J et al, Influence of reported study design characteristics on intervention effect estimates from randomized controlled trials. Ann Intern Med. 2012, 157(6), 429-438. doi: 10.7326/0003-4819-157-6-201209180-00537

Tierney JF, Stewart LA, Investigating patient exclusion bias in meta-analysis, International Journal of Epidemiology, 2005, 34(1), 79-87. doi: $10.1093 /$ ije/dyh300 


\section{Reply}

High risk of inadequate blinding due to side effects.

The purpose of pilot-tested trial designs, including the double-blind procedures used in TORCH, is to minimise performance bias to ensure that the test of the intervention is as fair as possible. Differences in side effects between study arms are identified after the study has concluded when data is analysed at the level of group. Side effects were recorded in both groups in 444 centres by a large number of trial staff during the study and it is unlikely that individual patients and clinicians would have been able to accurately identify the active intervention consistently across the study in a way that could have biased the outcome. Blinding failure cannot be separated from the accuracy of guesses during the conduct of a trial and in any case the overall aim of a good quality clinical trial is to identify differences under controlled conditions (Senn 2004). The revised CONSORT statement abandoned tests of blinding success based on an acknowledgement that they '...might actually be tests of hunches on harms, side-effects, or efficacy.' (Schultz 2010 Lancet). We therefore stand by our original risk of bias rating on blinding in TORCH.

High risk of attrition bias.

The impact of lack of data following withdrawal from a trial is complex. Data may be missing at random or may be missing because of a relationship with the intervention. The former 'missingness' is likely to be equally distributed between groups but the latter has the potential to bias the comparison between groups. Longitudinal data can be analysed using ITT principles, in the presence of missing data, but is characteristically associated with conservative estimates of the treatment effect. A strict definition of ITT would exclude analyses with missing outcome data, but such a standard is unattainable and the CONSORT guidelines have abandoned ITT in favour of specifically defining the numbers of participants in each trial arm (Schultz 2010 BMJ). The great strength of a clinical trial is the strictly controlled conditions under which the 'fair test' comparison is made but data collected outside of those conditions is unreliably collected and difficult to interpret. It is important to report follow-on data when it is available, but when this information is not available we should take a pragmatic approach, within the confines of the study protocol, to assess attrition bias. We therefore stand by our original risk of bias rating on attrition bias.

Sally Spencer, Charlotta Karner, Chris Cates, David Evans

References

Senn SJ. A blinkered view of blinding. BMJ Rapid Response of 20 February 2004. doi:10.1136/bmj.328. 74327.37952.631667

Schulz, KF, Altman, DG, Moher, D, Fergusson, D. CONSORT 2010 changes and testing blindness in RCTs. Lancet 2010; 375: 1144-46

Schulz, KF, Altman, DG, Moher, D. CONSORT 2010 statement: Updated guidelines for reporting parallel group randomised trials. BMJ 2010; 340: $\mathrm{c} 332$.

\section{Contributors}

Feedback submitters Nicole Giunio-Zorkin, Ruthdol Ywaya, Elissa Aeng, Aaron Tejani

Affiliation: Lower Mainland Pharmacy Services

Do you have any affiliation with or involvement in any organisation with a financial interest in the subject matter of your comment? I do not have any affiliation with or involvement in any organisation with a financial interest in the subject matter of my comment

WHAT'S NEW

\begin{tabular}{lll}
\hline Date & Event & Description \\
\hline 23 April 2018 & Amended & Response to feedback added. \\
\hline
\end{tabular}

\section{H I S T O R Y}

Protocol first published: Issue 2, 2008

Review first published: Issue 10, 2011 


\begin{tabular}{lll}
\hline Date & Event & Description \\
\hline 19 March 2018 & Amended & $\begin{array}{l}\text { Feedback received and added to the review. We await a response } \\
\text { from the author team. }\end{array}$ \\
\hline 11 April 2013 & Amended & NIHR acknowledgement added \\
\hline 4 November 2011 & $\begin{array}{l}\text { New citation required but conclusions } \\
\text { have not changed }\end{array}$ & Author byline amended \\
\hline
\end{tabular}

\section{CONTRIBUTIONS OF AUTHORS}

SS and DJE collated the articles. SS, DJE and CK extracted the data. CK, CC and SS performed the statistical analysis. SS, DJE, CK and CC wrote the review.

\section{DECLARATIONS OF INTEREST}

Sally Spencer has had consultancy arrangements with GlaxoSmithKline who make long-acting beta 2 -agonists and inhaled corticosteroids. She has also previously been funded by GlaxoSmithKline. David Evans, Christopher Cates and Charlotta Karner do not have any known conflicts of interest.

\section{SOURCES OF SUPPORT}

\section{Internal sources}

- St George's University of London, UK.

\section{External sources}

- NIHR, UK.

Programme grant funding

\section{DIFFERENCES BETWEEN PROTOCOL AND REVIEW}

Post-bronchodilator FEV1 was added as an outcome at the suggestion of a peer reviewer.

In the protocol we planned to assess study quality according to whether studies met the following pre-specified quality criteria (Handbook 2005):

I) adequacy of the randomisation procedure;

ii) demographic balance of study participants at baseline;

iii) adequacy of blinding procedures for concealing treatment allocation;

iv) adequacy of the reporting and handling of participants who withdrew from treatment.

By the time the review was written the guidelines for assessing study quality had been updated (Higgins 2008). We assessed the risk of bias for all included studies according to recommendations outlined in The Handbook for Systematic Reviews of Interventions (Higgins 2008) for the following items:

1. allocation sequence generation;

2. concealment of allocation;

3. blinding of participants and investigators;

4. incomplete outcome data;

5. selective outcome reporting.

We graded each potential source of bias as low, high or unclear risk of bias.

\section{INDEX TERMS}

\section{Medical Subject Headings (MeSH)}

Adrenal Cortex Hormones [*administration \& dosage]; Adrenergic beta-2 Receptor Agonists [ ${ }^{\star}$ administration \& dosage]; Albuterol [administration \& dosage] [analogs \& derivatives]; Androstadienes [administration \& dosage]; Bronchodilator Agents [administration 
\& dosage]; Budesonide [administration \& dosage]; Ethanolamines [administration \& dosage]; Fluticasone; Formoterol Fumarate; Pulmonary Disease, Chronic Obstructive [ ${ }^{\star}$ drug therapy]; Randomized Controlled Trials as Topic; Salmeterol Xinafoate

\section{MeSH check words}

Humans 